PAULO HENRIQUE ARCAS

UNIVERSIDADE DE SÃO PAULO

FACULDADE DE EDUCAÇÃO

\title{
Implicações da Progressão Continuada e do SARESP na Avaliação Escolar: tensões, dilemas e tendências
}

Tese apresentada à Faculdade de Educação da Universidade de São Paulo para obtenção do título de Doutor em Educação.

Área de Concentração: Estado, Sociedade e Educação.

Orientadora: Prof ${ }^{a}$. Dr ${ }^{\mathrm{a}}$. Sandra Maria Zákia Lian Sousa

São Paulo 
Autorizo a reprodução e divulgação total ou parcial deste trabalho, por qualquer meio convencional ou eletrônico, para fins de estudo e pesquisa, desde que citada a fonte.

\author{
Catalogação na Publicação
}

Serviço de Biblioteca e Documentação

Faculdade de Educação da Universidade de São Paulo

37.06(81.61) Arcas, Paulo Henrique

A668i Implicações da progressão continuada e do SARESP na avaliação escolar : tensões, dilemas e tendências / Paulo Henrique Arcas ; orientação Sandra Maria Zákia Lian Sousa. São Paulo : s.n., 2009.

178 p. il., tabs.

Tese (Doutorado - Programa de Pós-Graduação em Educação. Área de Concentração : Estado, Sociedade e Educação) - - Faculdade de Educação da Universidade de São Paulo.

1. Sistema de Avaliação do Rendimento Escolar do Estado de São Paulo 2. Avaliação da educação 3. Progressão continuada 4. Política educacional I. Sousa, Sandra Maria Zákia Lian, orient. 


\section{Implicações da Progressão Continuada e do SARESP na Avaliação Escolar: tensões, dilemas e tendências}

Tese apresentada à Faculdade de Educação da Universidade de São Paulo para obtenção do título de Doutor em Educação.

Área de Concentração: Estado, Sociedade e Educação.

Orientadora: Prof ${ }^{a}$. Dr ${ }^{a}$. Sandra Maria Zákia Lian Sousa

Tese defendida e aprovada em: I

\section{Banca Examinadora:}

Prof ${ }^{a}$ Dra. Sandra Zákia Lian Sousa (orientadora)

Universidade de São Paulo (USP)

Prof ${ }^{a}$ Dra. Alicia Maria Catalano de Bonamino

Pontifícia Universidade Católica do Rio de Janeiro (PUC-Rio)

Prof $^{\circ}$ Dr. Jefferson Mainardes

Universidade Estadual de Ponta Grossa (UEPG)

Prof $^{\circ}$ Dr. Luiz Carlos de Freitas

Universidade Estadual de Campinas (UNICAMP)

Prof $^{\circ}$ Dr. Ocimar Munhoz Alavarse

Universidade de São Paulo (USP) 

Peixe Vivo

A minha alma chorou tanto, Que de pranto está vazia Desde que aqui fiquei, Sem a sua companhia

Não há pranto sem saudade Nem amor sem alegria É por isso que eu reclamo Essa tua companhia

Como pode um peixe vivo Viver fora da água fria?

Como poderei viver Como poderei viver Sem a tua, sem a tua Sem a tua companhia? Sem a tua, sem a tua Sem a tua companhia?

(Folclore Mineiro)

À memória de meu pai Mario Arcas 



\section{AGRADECIMENTOS}

À Prof ${ }^{\mathrm{a}}$ Dra. Sandra Maria Zákia Lian Sousa, pelas orientações, pelo incentivo, pelo acompanhamento de todo o processo de elaboração deste trabalho, mas, principalmente, pela competência, pelo estímulo e pela paciência e dedicação que foram essenciais para a concretização da tese.

Ao Prof ${ }^{\circ}$ Dr. Luiz Carlos de Freitas (UNICAMP) e o Prof ${ }^{\circ}$ Dr. Ocimar Munhoz Alavarse (USP), que durante o exame de qualificação contribuíram com orientações preciosas para a elaboração deste trabalho.

Ao Prof $^{\circ}$ Dr. Jefferson Mainardes (UEPG) que, como suplente da banca de qualificação, gentilmente enviou seus comentários acerca do trabalho, contribuindo para a finalização deste estudo.

Aos professores e colegas do Centro de Estudos e Pesquisas em Políticas Públicas de Educação (CEPPPE), pelas oportunidades de estudo e reflexão.

Aos Funcionários do Programa de Pós Graduação da FEUSP e Secretárias do Departamento de Administração Escolar e Economia de Educação, que sempre estiveram à disposição para me atender e orientar nos momentos de dúvidas.

Aos amigos Andréia Steinvascher, Cristiane Machado, Débora Jeffrey e Ocimar Munhoz Alavarse cuja jornada iniciou-se no mestrado e muito colaboraram no meu crescimento.

À Valéria Lopes por sua amizade, carinho e apoio em todos os momentos.

À Beth Reymi pelo carinho e pelo valioso auxílio no desenvolvimento da pesquisa.

Aos meus irmãos, familiares e amigos que sempre tiveram uma palavra de apoio e estímulo para a concretização deste trabalho. 



\section{RESUMO}

Esta pesquisa buscou investigar as implicações da progressão continuada e do Sistema de Avaliação do Rendimento Escolar do Estado de São Paulo (SARESP) na avaliação escolar. Procurou-se identificar e analisar eventuais alterações ocorridas na avaliação, induzidas pela implantação dessas medidas. Para tanto, realizou-se investigação de natureza qualitativa, procedendo ao levantamento e análise de pesquisas acadêmicas acerca de ambos os temas, aplicação de questionários e realização de entrevistas com professores coordenadores de escolas de uma Diretoria Regional de Ensino da rede estadual paulista. Concluiu-se que tanto a progressão continuada como o SARESP estão refletindo na avaliação escolar. Identificou-se que a progressão continuada tende a influenciar mais o discurso do que as práticas avaliativas e enfrenta maior resistência do professorado. O SARESP tem assumido, gradualmente, o papel de orientador de práticas escolares, sendo utilizado no planejamento e replanejamento das escolas. Tem repercutido nas práticas avaliativas, induzindo ao fortalecimento de uma concepção de verificação escolar, em detrimento da avaliação formativa, potencializada pela progressão continuada. $\mathrm{O}$ dilema causado pela convivência dessas medidas evidencia um confronto entre a lógica da avaliação formativa com práticas tradicionalmente desenvolvidas nas escolas, que tendem a restringir a avaliação à medida de resultados, com fim classificatório. O SARESP, ao servir como referência para organização das práticas escolares e avaliativas, potencializa a tensão entre a avaliação tradicional e a avaliação formativa. Devido à importância que tem adquirido na política educacional, evidenciou-se a tendência em tornar-se, gradativamente, indutor do trabalho escolar.

Palavras-chave: Progressão continuada, SARESP, avaliação escolar, política educacional. 


\begin{abstract}
This research has served the purpose to investigate the implications of continuous progress and Student Performance Appraisal System in the State of São Paulo (SARESP) on school evaluation. We have identified and analyzed alterations on the evaluations which were induced by the implementation of these procedures. Therefore, we proceeded to investigate the qualitative nature of these implications by analyzing data from academic research around both topics; we also applied some questionnaires and interviews with coordinators from schools of a Regional Directory in the local public school system. We have come to the conclusion that both the continuous progress and SARESP affect school evaluation. The continuous progress has a tendency to affect rather the discourses than the evaluative practices and teachers are much more resistant to it. SARESP has gradually taken up the role of a practice guide and it is used for school planning. We can see its effect on evaluative practices invigorating some conception of school assessment to the loss of formative evaluation which has been maximized by continuous progress. The dilemma that has arisen from these two procedures sheds some light on the confrontation between the logic of formative evaluation and traditionally-developed practices at schools which tend to narrow evaluations to mere results in order to achieve classification. SARESP, when it serves as a guide to the organization of school and evaluative practices, maximize the tension between traditional and formative evaluations. Due to its relevance in the educational politics, it is evident that it will gradually become an organizer for school practices.
\end{abstract}

Key words: continuous progress, SARESP, school evaluation, educational politics. 


\section{RESUMEN}

Este estudio buscó investigar las implicaciones de la progresión continua y del Sistema de Evaluación del Rendimiento Escolar del Estado de São Paulo (SARESP) en la evaluación escolar. Se trató de identificar y analizar eventuales cambios en la evaluación inducidos por la aplicación de estas medidas. Para eso, se realizó una investigación de carácter cualitativo, procediendo a la búsqueda y análisis de pesquisas académicas acerca de ambos los temas, la aplicación de cuestionarios y la realización de entrevistas con profesores coordinadores de escuelas bajo jurisdicción de una Delegación Regional de Educación del estado de São Paulo. Se llegó a la conclusión que tanto la progresión continua como el SARESP se reflejan en la evaluación escolar. Se identificó que la progresión continua tiende a influir en el discurso más que las prácticas evaluativas y enfrenta una mayor resistencia por parte del profesorado. El SARESP viene asumiendo, gradualmente, el papel de orientador de prácticas escolares, siendo utilizado en la planificación y replanificación en las escuelas. Viene repercutiendo en las prácticas evaluativas, llevando al fortalecimiento de una concepción de verificación escolar, en lugar de la evaluación formativa, potencializada por la progresión continua. El dilema causado por la coexistencia de estas medidas pone de manifiesto una confrontación entre la lógica de la evaluación formativa con las prácticas tradicionalmente desarrolladas en las escuelas, que tienden a restringir la evaluación a medir resultados solamente para establecer una clasificación. El SARESP al servir de referencia a la organización de las

prácticas escolares y evaluativas, maximiza la tensión entre la evaluación tradicional y la evaluación formativa. Dada la importancia que viene adquiriendo en la política educacional, presenta tendencia a convertirse, gradualmente, en inductor del trabajo en la escuela.

Palabras clave: Progresión continua, SARESP, evaluación escolar, política educacional. 


\section{LISTA DE SIGLAS}

APASE - Sindicato de Supervisores do Magistério do Estado de São Paulo

APEOESP - Associação dos Profissionais do Ensino Oficial do Estado de São Paulo

ATP - Assistente Técnico-Pedagógico

CEE - Conselho Estadual de Educação

CENP - Coordenadoria de Normas Pedagógicas

CPP - Centro do Professorado Paulista

DRE - Dirigente Regional de Ensino

EJA - Educação de Jovens e Adultos

HTPC - Horário de Trabalho Pedagógico Coletivo

IDESP - Índice de Desenvolvimento da Educação no Estado de São Paulo

INEP - Instituto Nacional de Estudos e Pesquisas Educacionais

LDB - Lei de Diretrizes e Bases da Educação Nacional

PC - Professor Coordenador

SAEB - Sistema Nacional de Avaliação da Educação Básica

SARESP - Sistema de Avaliação do Rendimento Escolar do Estado de São Paulo

SEE - Secretaria de Estado da Educação de São Paulo

TRI - Teoria da Resposta ao Item

UDEMO - Sindicato de Especialistas de Educação do Magistério Oficial do Estado de São Paulo 


\section{LISTA DE TABELAS}

Tabela 1 - Dissertações e Teses sobre progressão continuada defendidas no período de 2000 a 2007 39

Tabela 2 - Conclusões recorrentes em dissertações e teses sobre progressão continuada 39

Tabela 3 - Dados gerais dos professores coordenadores entrevistados 105 



\section{SUMÁRIO}

INTRODUÇÃ

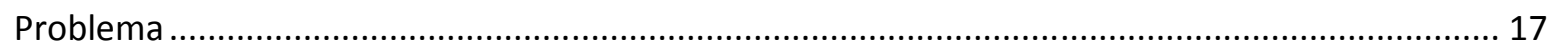

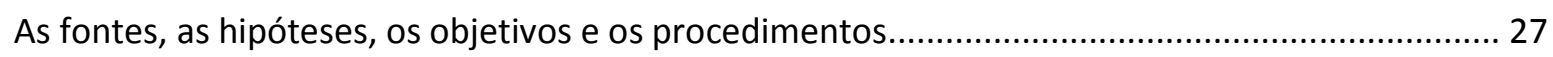

Capítulo I - PROGRESSÃO CONTINUADA NA REDE ESTADUAL PAULISTA........................... 33

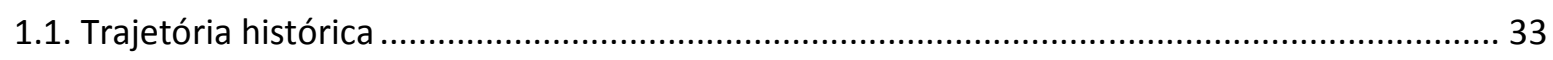

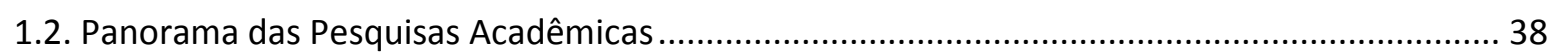

Capítulo II - O SISTEMA DE AVALIAÇÃO DO RENDIMENTO ESCOLAR DO ESTADO DE

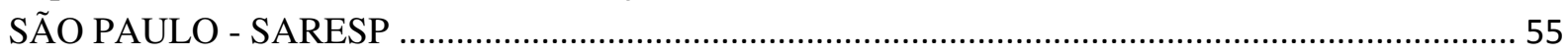

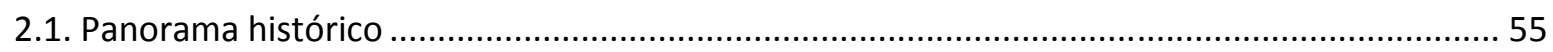

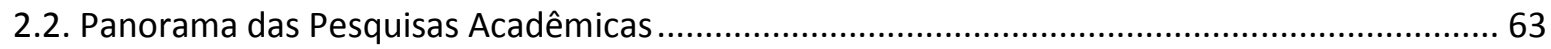

CAPÍTULO III - PROGRESSÃO CONTINUADA, SARESP E AVALIAÇÃO ESCOLAR: O QUE

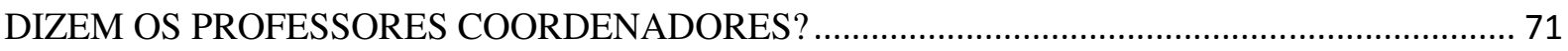

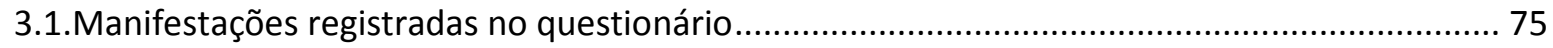

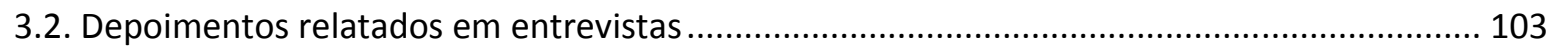

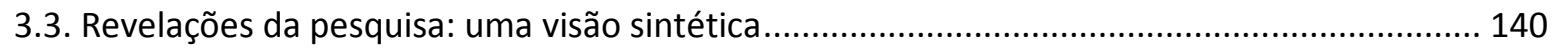

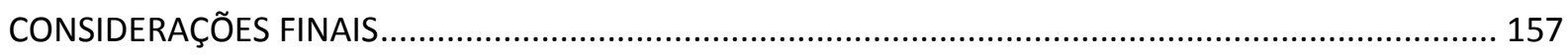

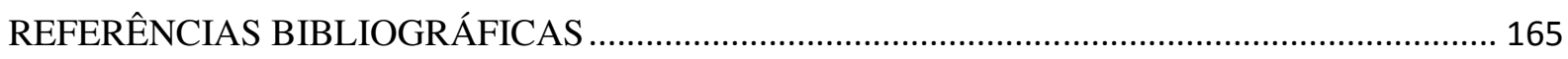

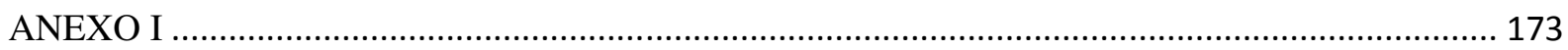

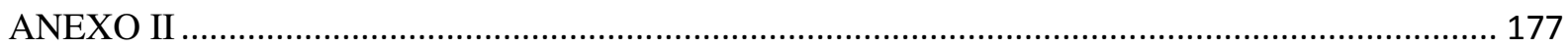




\section{INTRODUÇÃO}

\section{Problema}

Nos anos finais do século XX e nesses anos iniciais do século XXI, a avaliação ganhou enorme destaque nas políticas educacionais empreendidas no Brasil. Esse destaque pode ser identificado pelo crescimento de pesquisas acadêmicas que têm como foco a avaliação e, é claro, pelas agendas do Ministério e das Secretarias de Educação. Aliás, não são poucos os artigos e produções de natureza acadêmica que iniciam fazendo referência à importância que a avaliação tem assumido nas políticas públicas, em especial na educação, ressaltando sua 'centralidade’ nessas políticas. Sendo assim, o discurso e o debate em torno da avaliação no presente momento em nosso país, por si só, de certa forma, justifica a necessidade de se pensar a avaliação no contexto das políticas educacionais.

Enquanto campo de pesquisa, a avaliação se apresenta como um objeto multifacetado e complexo. Há algumas décadas, no Brasil, quando nos referíamos à avaliação tratava-se, quase que exclusivamente, da avaliação da aprendizagem feita em sala de aula pelo professor para verificação do que os alunos haviam aprendido. Hoje, quando se fala de avaliação faz-se necessário adjetivá-la, caracterizando-a como da aprendizagem, de sistemas, de programas, em larga escala, institucional, auto-avaliação, entre outros focos. Pesquisas e estudos que vêm sendo feitos para avaliar a avaliação são chamados de meta-avaliação:

A avaliação, entretanto, no seu devenir sofreu transformações e gerou novas
construções. É um constante vir-a-ser na área das ciências do homem,
tornando-se uma atividade complexa, fundamentada no pensamento
descritivo, analítico e crítico. O seu enfoque não está circunscrito ao aluno e
seu rendimento, ao desenvolvimento de atitudes e de interesses, que
constituem o produto do processo instrucional que ocorre na escola. O seu
interesse se ampliou, mas não ficou no âmbito da microavaliação. Passou a
se interessar por grupos de indivíduos (alunos, professores, administradores,
técnicos etc.); projetos, produtos e materiais; instituições e sistemas
educacionais nos seus mais diversos níveis e competências administrativas,
evoluindo, assim, para uma área bem mais ampla, que constitui o campo de
macroavaliação. (VIANNA, 2000, p.22)

Isto posto, ao tratar do tema da avaliação em uma pesquisa acadêmica não se tem grande dificuldade em se justificar a sua escolha. Mas torna-se necessário delimitar o objeto, já que, devido a sua amplitude, não pode ser abarcado na sua totalidade. 
Duas medidas adotadas pela Secretaria de Estado da Educação de São Paulo (SEE) são tomadas como objeto dessa pesquisa: o Sistema de Avaliação do Rendimento Escolar do Estado de São Paulo (SARESP), criado em 1996, e o regime de progressão continuada, adotado em 1998. Essas medidas remetem diretamente à avaliação escolar. A primeira introduziu uma prática avaliativa com a qual a rede de ensino não estava habituada, a avaliação externa; a segunda, por alterar a progressão escolar, fez supor a promoção de mudanças na avaliação da aprendizagem.

A adoção de medidas que se vinculam diretamente a avaliação, como o SARESP, ou que podem modificar concepções e práticas avaliativas, caso da progressão continuada, faz com que os olhares se voltem para a questão da avaliação nas escolas; qual seu significado, função, qual sua relação e importância para o ensino e para a aprendizagem.

Portanto, a centralidade da avaliação nas políticas educacionais pode ser evidenciada tanto em relação à avaliação interna, feita pelos professores, quanto à avaliação externa, iniciativa dos gestores dos sistemas de ensino. Ambas podem influenciar as práticas escolares, pois são iniciativas que afetam, em maior ou menor intensidade, concepções e práticas avaliativas desenvolvidas nas escolas. Sobre as avaliações externas e internas, Vianna (2003) comenta:

Quando nos referimos às avaliações internas, temos em mente aquelas realizadas pelas escolas. É evidente que a avaliação na escola é parte do processo formativo, constituindo o trinômio ensino-aprendizagem-avaliação, sob a orientação do professor. [...]

As avaliações externas, realizadas quase sempre mediante proposta dos órgãos diretivos do sistema (Ministério da Educação, Secretarias de Estado da Educação), são recomendáveis, na medida em que representam um trabalho não comprometido com a administração educacional e as políticas que a orientam. (p. 17-18)

Durante os anos de 1980, fundamentalmente, estudos no campo da avaliação da aprendizagem denunciaram o caráter classificatório e excludente da avaliação, relacionando as práticas avaliativas aos altos índices de repetência e à necessidade de mudança nas concepções e práticas historicamente desenvolvidas nas escolas como forma de combater o fracasso escolar e de garantir a aprendizagem e a democratização do ensino. Esses estudos tiveram muito impacto no meio educacional, promoveram debates, discussões, estudos e iniciativas de mudanças na avaliação. Apesar de sua relevância e divulgação não foram suficientes para promover a ruptura com a cultura avaliativa tradicional, caracterizada essencialmente pela verificação da aprendizagem e a atribuição de notas ou conceitos com 
fins classificatórios. Esta idéia de avaliação encontra-se, ainda hoje, arraigada em práticas escolares e na mentalidade de pais, professores e da sociedade como um todo, como tem sido revelado por inúmeras pesquisas feitas sobre esta temática.

Nos anos 1980, podemos dar destaque para os estudos realizados por Cipriano Carlos Luckesi, Ana Maria Saul, Sandra Zákia Lian Sousa, Clarilza Prado Sousa, Luiz Carlos de Freitas, dentre outros. Na década seguinte, a pesquisa se ampliaria e os trabalhos em torno da avaliação proliferariam cada vez mais.

Ainda nos anos 1980, políticas implantadas nas escolas visando enfrentar o fracasso escolar também incidiam sobre concepções e práticas avaliativas e, dentre as mais significativas, citamos a introdução do chamado ciclo básico de alfabetização, medida essa adotada com maior impacto nas redes de ensino dos estados de São Paulo, em 1984; Minas Gerais, em 1985; Paraná e Goiás, ambos em 1988.

O ciclo básico de alfabetização, ao eliminar a possibilidade de reprovação entre a $1^{\mathrm{a}} \mathrm{e}$ a $2^{\mathrm{a}}$ séries do antigo $1^{\mathrm{o}}$ grau, atualmente Ensino Fundamental, e ao fundamentar-se em uma concepção de alfabetização calcada no chamado construtivismo, induziu a uma reflexão sobre o papel da avaliação no processo de ensino e aprendizagem, promovendo outro significado, com ênfase no seu caráter mais formativo. Mainardes (2001) indica a importância do ciclo básico como marco na retomada das discussões acerca da eliminação da reprovação e da organização seriada de ensino, pois representou "uma ruptura com a idéia da simples promoção automática, subsidiando a possibilidade da implantação do ensino por ciclos nas demais séries do Ensino Fundamental” (p. 45).

Nos anos 1990, também políticas de enfrentamento do fracasso escolar que objetivavam a melhoria da qualidade do ensino tiveram nos ciclos uma proposta de mudança do ensino e de promoção da aprendizagem. Portanto, nessa década, vimos diferentes governos adotando a organização do ensino em ciclos e, com isto, de alguma forma induzindo o repensar da função da avaliação da aprendizagem. Ressalta-se que essa organização do ensino recebeu apoio de grande parte do meio acadêmico. As críticas que têm sido divulgadas em produções acadêmicas tendem a se referir às formas de implantação e implementação e não à idéia em si, como observa Mainardes (2007):

Os campos oficial e pedagógico têm considerado a escola em ciclos como uma política inovadora e positiva, pois elimina ou diminui significativamente a reprovação, proporciona aos alunos um maior tempo 
para a aprendizagem e permite aos profissionais da educação avançarem nas suas concepções e práticas. Desde os anos 1990, não tem havido uma separação clara entre os campos oficial e pedagógico. Há uma visão quase consensual que os ciclos são válidos e que devem ser mantidos e aperfeiçoados, bem como implantados em redes que ainda utilizam a seriação. (p.74)

Em 1996, com a promulgação da Lei de Diretrizes e Bases da Educação Nacional (LDB) ${ }^{1}$, os ciclos passam a ser considerados como alternativa de organização do ensino, conforme disposto em seu artigo 23. A partir daí, intensifica-se a adoção dos ciclos e do regime de progressão continuada no Ensino Fundamental, principalmente nas regiões sudeste e sul, caso das redes estaduais de São Paulo (1997) e Minas Gerais (1997):

A nova LDB veio abrigar a idéia da organização da escolaridade em ciclos. Assim, vários Estados e Municípios estão implantando ou reformulando propostas já existentes, recolocando a discussão que, a partir da década de 50 , configurou a promoção automática. No atual contexto, há a necessidade de ampliar a discussão dessa proposta da organização da escolaridade em ciclos. (MAINARDES, 2001, p.36)

É o que ocorreu no estado de São Paulo quando, a partir de 1998, são adotados ciclos em regime de progressão continuada. Com esta medida, toda a rede estadual passou a ter o Ensino Fundamental organizado em dois ciclos de quatro anos, sendo permitida a reprovação apenas ao final de cada ciclo, ou seja, após os quatro primeiros anos e ao final do Ensino Fundamental. A reprovação no interior dos ciclos somente é possível por freqüência inferior a $75 \%$ do total da carga horária anual.

A adoção dos ciclos em regime de progressão continuada atinge diretamente a avaliação, pois apesar da existência do ciclo básico em São Paulo, desde 1984, e da difusão de concepções de avaliação da aprendizagem com ênfase no seu aspecto formativo, de modo geral, imperava na rede estadual uma avaliação extremamente vinculada à finalidade de promoção ou de retenção do aluno ao final do ano letivo. Ao se eliminar a possibilidade de reprovação por aproveitamento escolar em determinados momentos do Ensino Fundamental, gerou-se uma situação em que a avaliação, objetivando a decisão da reprovação ou aprovação, não faz sentido:

\footnotetext{
${ }^{1}$ Importante lembrar que a legislação anterior à Lei 9.394/96, Lei 5.692/71, já possibilitava a organização do ensino de outras formas, além da seriada. Ver Sousa (1986); Steinvascher (2003) e Mainardes (2007).
} 
Esse tem sido considerado o aspecto mais desestabilizador do trabalho escolar, exatamente porque se confronta com a pedagogia do exame, lógica norteadora das rotinas e práticas escolares, bem como das expectativas de professores, alunos e pais. No limite, os ciclos põem em questão a finalidade da avaliação, que tradicionalmente tem sido associada à seleção e classificação dos alunos, tendo por finalidade decidir sobre a sua promoção ou retenção para a série subseqüente. (SOUSA e BARRETTO, 2005, p.674675)

Em pesquisa realizada no Mestrado, intitulada "Avaliação da aprendizagem no regime de progressão continuada: o que dizem os alunos," procuramos identificar esse movimento de ressignificação da avaliação da aprendizagem no interior de uma escola de Ensino Fundamental da rede pública de ensino paulista. $\mathrm{Na}$ ocasião, constatou-se que a ressignificação da avaliação se revelava mais no âmbito do projeto pedagógico, nos planos de ensino e demais documentos da escola analisados do que nas práticas escolares. A necessidade de ressignificar a avaliação expressa nos documentos foi evidenciada na fala dos professores, entretanto, nas entrevistas com os alunos, o que se evidenciava era a permanência de uma prática classificatória e excludente e que mantinha um caráter de disciplinamento das crianças.

[...] na fala dos alunos, a avaliação continua assumindo apenas um papel de verificação e classificação. Em quatro das respostas selecionadas como exemplo, os alunos disseram que a avaliação serve "pra gente", portanto, na fala dos alunos, a avaliação diz respeito a ele. E, mesmo na vigência da progressão continuada, parece que o final do bimestre e o final do ano ainda exercem um papel preponderante no tocante a avaliação da aprendizagem.

Perguntados sobre como age o professor quando os alunos não conseguem conceito satisfatório no bimestre, os alunos responderam que "conversa com o aluno"; "chama a família"; "põe na recuperação". Assim como a avaliação parece ser apenas do aluno, modificar o resultado obtido parece ser tarefa somente do aluno, quando muito do aluno e da família. Na fala dos alunos não pude perceber qual é o papel do professor nesse processo, que procedimentos ele desenvolve para auxiliar a aprendizagem desses alunos, que modificações ocorrem em sua aula para favorecer a aprendizagem. (ARCAS, 2003, p. 96)

As manifestações dos alunos entrevistados possibilitaram identificar a permanência de uma avaliação que tende a responsabilizar o aluno e sua família pelo seu desempenho insuficiente. A partir do resultado da avaliação o professor não revê sua ação, não repensa seu planejamento, apenas atribui uma nota. Mesmo quando toma alguma medida no sentido de promover a aprendizagem para seus alunos, como encaminhá-lo para a recuperação paralela, o professor não se coloca como responsável pela aprendizagem. 
Se por um lado se tem evidências de que as políticas de organização do ensino não foram suficientes para mudar radicalmente a avaliação, é inegável que essas iniciativas, ao menos, vêm desestabilizando as práticas escolares no tocante a avaliação e muitas pesquisas têm procurado identificar o que vem ocorrendo com a avaliação da aprendizagem no interior das escolas ${ }^{2}$.

A avaliação ganha centralidade em decorrência do fato de as iniciativas de ruptura com a organização não seriada de ensino virem acompanhadas da implantação da progressão escolar, que supõe a supressão da idéia de reprovação, ao menos entre um dado número de anos escolares. Como tradicionalmente a noção de avaliação tem sido associada prioritariamente a uma finalidade seletiva e classificatória, que tem por fim a decisão quanto à promoção e retenção dos alunos para a série subseqüente, no limite, os ciclos, põem em questão tal finalidade da avaliação. (SOUSA e BARRETO, 2004, p. 21)

Sobre eventuais impactos dos ciclos nos processos avaliativos, Sousa comenta:

Certamente, dentre todas as práticas e rotinas escolares, aquela que mais diretamente é "abalada" com a implantação dos ciclos é a avaliação, sendo sua resignificação na prática escolar necessária para tornar realidade à reorganização do processo educativo. Em decorrência, é em relação à avaliação que incide a maior parte dos questionamentos que vêm sendo feitos por professores, alunos e pais, quando da implantação de ciclos, na medida em que resulta na introdução da progressão continuada. (Sousa, 1999, p.39)

$\mathrm{Na}$ pesquisa de Mestrado também nos deparamos com a influência da avaliação externa no interior da escola. Assim como as políticas de organização do ensino em ciclos e a adoção da progressão continuada influenciam na avaliação da aprendizagem, a avaliação externa tendia a promover mudanças nas práticas escolares. O que foi identificado é que a existência de uma prova anual era utilizada por alguns professores como forma de convencimento para que os alunos estudassem, pois se não havia a possibilidade de reprovação devido à progressão continuada, a avaliação externa poderia ser um instrumento para tal, já que no ano de 2001, isso ocorrera de fato ${ }^{3}$ :

[...] perguntamos aos entrevistados se eles sabiam o que é o SARESP e para o que serve, obtendo respostas tais como: "É a prova do governo" e "Para decidir quem vai passar de ano". Alguns não souberam explicar o que é o

\footnotetext{
${ }^{2}$ Como exemplo, podemos citar as obras de PARO (2001) e FREITAS (2003) e as pesquisas de ARCAS (2003), BERTAGNA (2003) e POLICHE (2006), dentre outras.

${ }^{3}$ Em 2001 o SARESP avaliou as séries finais dos ciclos e a Secretaria de Educação utilizou o resultado da avaliação para decidir sobre a aprovação ou reprovação dos alunos. Ver ARCAS (2003).
} 
SARESP, mas disseram já ter ouvido falar. O que todos acham é que "é uma prova difícil; mais difícil que o provão" (prova feita pela escola periodicamente). (ARCAS, 2003, p.101)

Bonamino (2002), ao traçar o percurso da avaliação externa no Brasil, situa o ponto de partida na década de 1980, no contexto de redemocratização do país, do crescente processo de universalização do acesso ao ensino de $1^{\circ}$ grau, hoje Ensino Fundamental, e a seletividade escolar que marcava este grau de ensino:

Ao longo da década, a preocupação com as excessivas taxas de repetência e com a evasão precoce dos alunos, principalmente os das camadas populares, levou à implantação de políticas de não-reprovação e de avaliação continuada, à construção de novas escolas, ao treinamento ampliado de professores, à distribuição de livros didáticos. No final dos anos 80 , o reconhecimento da inexistência de estudos que mostrassem mais claramente $\mathrm{o}$ atendimento educacional oferecido à população e seu peso sobre o desempenho dos alunos dentro do sistema escolar conduziu às primeiras experiências de avaliação do ensino de $1^{\circ}$ grau (p. 15).

Se as políticas de adoção de ciclos e de progressão continuada ganharam impulso na década de 1980, a avaliação externa desencadeou-se no final da mesma década, como mostra Bonamino, intensificando-se na década seguinte, com a criação do Sistema Nacional de Avaliação da Educação Básica (SAEB) pelo governo federal. Tendo como foco a avaliação do desempenho escolar dos estudantes, o SAEB foi desenvolvido com vistas a subsidiar políticas que visem à melhoria da qualidade da educação. No estado de São Paulo, em 1996, foi criado o Sistema de Avaliação do Rendimento Escolar do Estado de São Paulo (SARESP), com delineamento semelhante ao do SAEB.

A avaliação externa não era uma prática comum antes da segunda metade dos anos 1990. Algumas avaliações haviam ocorrido nos anos anteriores, entretanto, é com a criação do SAEB, pelo Governo Federal, que a avaliação externa iria começar a se disseminar pelo país ${ }^{4}$.

No entanto, a falta de uma tradição de avaliação externa no Brasil, usualmente, faz com que os profissionais da educação a vejam com certa desconfiança, como diz Gatti:

\footnotetext{
${ }^{4}$ Segundo Sousa (2001, p.84) "no Brasil registra-se desde a década de 60 a ampliação do uso de testes educacionais; no entanto, situa-se nos anos finais da década de 80 a primeira iniciativa de organização de um sistema de avaliação do ensino básico, em âmbito nacional, denominado, a partir de 1991, Sistema Nacional de Avaliação da Educação Básica (SAEB), conduzido pelo Instituto Nacional de Estudos e Pesquisas Educacionais (INEP), do Ministério da Educação, apresentado como um sistema de monitoramento contínuo, capaz de subsidiar as políticas de ensino".
} 
Professores e técnicos de ensino, ao invés de perceberem na avaliação uma possibilidade de aprimorarem seu trabalho, construindo uma escola de qualidade, sentem-se, em geral, muito inseguros quanto ao seu futuro profissional: eventuais resultados negativos podem implicar um fracasso no exercício da profissão e apontar responsabilidades não cumpridas. [...] Há, de certa maneira, no ambiente escolar, um clima que não favorece o desenvolvimento de processos avaliativos externos e de âmbito mais amplo e, neste sentido, há muito que fazer para demonstrar o caráter não punitivo dos processos de avaliação e, sim, seu caráter pedagógico e auxiliar na superação de dificuldades. (1994, P.78-79)

No caso da avaliação externa desenvolvida no estado de São Paulo, há certa desconfiança sobre o que se pretende ao avaliar o sistema de ensino, gerando, inclusive, algumas resistências, como revelado nas pesquisas de Oliveira (1998) e Felipe (1999). Parte dessas resistências deriva da dúvida quanto ao uso dos resultados das avaliações, pois, tradicionalmente, tem-se uma compreensão de que a avaliação tem um caráter punitivo e de controle, justificando-se, assim, alguns temores por parte do professorado. Registra-se que os resultados da avaliação em São Paulo já foram utilizados para classificar, premiar e punir as escolas, além de serem utilizados para premiar e punir professores por meio de compensação financeira ${ }^{5}$.

Em 2001, Sousa publica artigo onde problematiza avaliações realizadas pelo Ministério da Educação em diferentes níveis de ensino, destacando "o papel central que a avaliação assume na formulação e implementação das políticas educacionais, como expressão de um movimento mais amplo de redefinição do papel do Estado.” (p.69) No artigo, Sousa aponta algumas características que são comuns às diferentes iniciativas de avaliação, ressaltado a ênfase nos produtos ou resultados; a meritocracia; o escalonamento dos resultados, implicando em uma classificação; o predomínio dos dados qualitativos e uma ênfase na avaliação externa, não havendo articulação com outros modelos de avaliação, principalmente com a auto-avaliação. Com esta análise Sousa alertava que:

Pautada por tais características, a avaliação tende a imprimir uma dada lógica e dinâmica organizacional nos sistemas de ensino, que se expressam no estímulo à competição entre as instituições educacionais e no interior delas, refletindo-se na forma de gestão e no currículo. Quanto ao currículo, destaca-se sua possível conformação aos testes de rendimento aplicados aos alunos; quanto à gestão, a perspectiva apontada é a de eventual

\footnotetext{
${ }^{5}$ Desde a gestão de Rose Neubauer (1994-2002) frente à Secretaria de Estado da Educação de São Paulo vem sendo pago um "bônus" aos profissionais que integram o quadro do magistério público. Um dos indicadores considerados no cálculo do "bônus" é o resultado do SARESP. Quanto melhor o resultado maior o "bônus".
} 
fortalecimento de mecanismos discriminatórios, com excessiva ênfase na racionalidade técnica. (2001, p. 90-91)

Broadfoot (1996) ao sinalizar os rumos que a avaliação vinha adquirindo em alguns países do mundo, demonstra que o gerenciamento do sistema educacional passa a ser orientado por seus resultados, exercendo a avaliação a função de controle sobre os serviços educacionais e prestação de contas ao Estado e à sociedade.

Em artigo publicado em 2003, Sousa retoma essa mesma discussão e reafirma a tendência apontada anteriormente, reforçando uma das idéias já expressas, a relação entre premiação ou punição e a conformação do que se ensina nas escolas, ou seja, "o poder dos testes de rendimento vir a conformar o que se ensina nas escolas" (p.181). Vale lembrar, entretanto, que a autora, em ambos os artigos, não se posiciona contrariamente a avaliação externa, mas suas preocupações centravam-se no papel que ela vinha assumindo e nos objetivos que o Estado explicitava naquele momento.

A princípio, a tendência do professorado era tratar, tanto as políticas de adoção dos ciclos e de progressão continuada, bem como as avaliações externas como modismo, políticas passageiras, sob a crença de que após a mudança das gestões que as implantaram haveria um retorno à situação anterior. Entretanto, após mais de quinze anos de implantação dessas medidas no Brasil e, em particular no estado de São Paulo, vemos uma manutenção dessas políticas, independente de críticas e resistências manifestadas por diferentes setores da comunidade escolar e da sociedade em geral ${ }^{6}$. No caso do estado de São Paulo, na atual gestão iniciada em agosto de 2007, vemos o fortalecimento e incremento da política de avaliação externa, o que abordaremos, com maior detalhamento, no decorrer deste estudo.

Barretto, ao analisar alguns modelos de avaliação propostos para o ensino básico, conclui que existem dois discursos em relação à avaliação educacional. Segundo a autora:

Um dos discursos reporta-se essencialmente à avaliação qualitativa do ensino, valoriza o processo de aprendizagem, concentra-se na avaliação feita no interior da própria escola pelos atores educacionais. Ele vem sendo reforçado pela expansão do regime de ciclos escolares, cujos pressupostos são os de garantir a continuidade da escolarização sem as rupturas

\footnotetext{
${ }^{6}$ Estudo intitulado "Cartografia da Avaliação Educacional no Brasil” (LOPES, 2007), identificou a existência, em 15 estados brasileiros, de iniciativas de avaliação educacional externa, sendo a mais antiga delas, criada no Ceará, em 1992. O estudo aponta, ainda, a tendência de disseminação dos sistemas de avaliação, uma vez que cinco estados brasileiros estavam, à época, elaborando propostas para a criação de seus sistemas.
} 
provocadas pela repetência e o de possibilitar a criação de condições para que a escola trabalhe diferentemente com a diversidade dos alunos.

O outro discurso propõe-se a oferecer indicadores da qualidade do ensino, volta-se para a apreciação de resultados padronizados, valoriza o produto da aprendizagem, utiliza largamente recursos quantitativos e de alta tecnologia e recorre à avaliação externa do rendimento escolar. Assenta-se, por sua vez, na apreciação exclusiva de alguns aspectos cognitivos do currículo, deixando de lado dimensões da formação do educando não só muito valorizadas socialmente, como incorporadas nas próprias diretrizes do ensino. (2001, p.62-63)

$\mathrm{Na}$ rede estadual de ensino paulista esses dois discursos podem ser identificados na implantação das duas medidas já citadas anteriormente. A organização do ensino em ciclos e adoção do regime de progressão continuada que se afina com o primeiro discurso apontado por Barreto, enquanto que a implantação do Sistema de Avaliação do Rendimento Escolar de São Paulo (SARESP) vai ao encontro do segundo discurso, com reflexos na dinâmica do trabalho escolar. Como assinalam Sousa e Barretto:

A partir dos anos 90, a contrapartida dos ciclos, em muitos sistemas de ensino, tem sido a avaliação externa do rendimento escolar. Nesses casos, freqüentemente é criada uma tensão nas escolas, qual seja: demanda-se que elas recorram à sua relativa autonomia para desenvolver um currículo capaz de contemplar as diferenças no que elas têm de fundamentos, de direitos e, ao mesmo tempo, exige-se que elas se conformem a critérios de avaliação que se referem a ganhos comuns dos alunos. A tendência, no enfrentamento dessa tensão, termina sendo a orientação dos tempos e espaços de aprendizagem em torno dos conteúdos exigidos nas provas de aferição do rendimento, bem mais restritos do que os objetivos educacionais propostos para o ensino. A expectativa de que as escolas procedam do modo que quiserem ou puderem no que toca às abordagens do conteúdo e à sua organização, mas cheguem aos resultados esperados pelo sistema, tem assim contribuído, na prática, para reforçar as rotinas tradicionais ao invés de revertê-las para dar lugar a uma lógica menos seletiva (SOUSA e BARRETTO, 2004, p. 24).

Nesta pesquisa pretende-se identificar como esses discursos, por meio das impressões evidenciadas pelos professores coordenadores, estão dialogando com as práticas escolares de avaliação; como essas medidas têm influenciado as práticas avaliativas, ou seja, que mudanças, permanências ou adaptações estão sendo feitas diante da eliminação da reprovação e dos resultados das avaliações externas. Por meio das opiniões manifestadas em entrevistas por professores coordenadores, procuramos apreender as implicações da progressão continuada e do SARESP na avaliação escolar.

A partir do panorama esboçado anteriormente e da permanência por mais de uma década das políticas de avaliação externa e de organização do ensino em ciclos e da adoção da 
progressão continuada, consideramos de fundamental importância identificar como vêm influenciando a avaliação escolar.

\section{As fontes, as hipóteses, os objetivos e os procedimentos}

Para a realização da pesquisa foi desenvolvido estudo da produção acadêmica a respeito do tema, procurando identificar o que essa produção indica sobre a avaliação escolar no contexto da progressão continuada e do SARESP. Após mais de uma década de implantação dessas medidas identifica-se uma produção bastante significativa sobre ambas as temáticas. Entretanto, estudos que tiveram como foco a influência que essas medidas estão acarretando para a avaliação escolar ainda são escassos.

Sousa ao discorrer a respeito do desenvolvimento de estudos na área da avaliação considera:

[...] oportuna a realização de pesquisas que se voltem à investigação de efeitos e impactos que vêm sendo produzidos com as iniciativas em curso no Brasil, direcionadas a diferentes focos e aos diversos níveis de ensino. Por exemplo, que impactos vêm sendo gerados na organização escolar, na cultura escolar, com a reorganização curricular em ciclos e, por decorrência, a necessidade de que seja vivenciada a avaliação contínua do aluno e do trabalho escolar? Paralelamente a medidas dessa natureza assiste-se à intensificação de avaliações externas que tomam o rendimento apresentado por alunos em testes como principal indicador de qualidade do ensino. Como a escola está agindo ou reagindo a essas iniciativas? Como a escola tem lidado, por um lado, como uma concepção de avaliação que visa o acompanhamento e estímulo ao desenvolvimento dos alunos, tendo em conta as diferenças individuais e mesmo de origem de classe social e, por outro lado, com a avaliação externa que dá centralidade à mensuração de desempenho dos alunos em testes, pressupondo, por exemplo, que após o terceiro ano o aluno seja capaz de..., ou seja, as avaliações externas começam a pautar alguns parâmetros de desejabilidade no processo de escolarização. Há um controle externo do próprio currículo escolar, correndo-se o risco de se estar abrindo mão da constituição de um processo avaliativo em função de uma mera mensuração $(2002$, p.114).

Sousa ainda enfatiza ser "necessário que se intensifiquem os estudos sobre os reais efeitos que têm gerado as avaliações" (idem, p.114). 
Alavarse (2007) alerta para a necessidade de uma articulação entre diferentes vertentes da avaliação, o que justifica a importância de se pesquisar o que vem ocorrendo com a avaliação da aprendizagem e a avaliação externa na rede pública do estado de São Paulo.

A implementação da organização em ciclos impõe, entre outros aspectos, que a avaliação não se processe apenas em torno do desempenho dos alunos, a chamada avaliação da aprendizagem. Exige uma avaliação da escola, de seu projeto, e substancialmente de seu currículo, enfim, uma avaliação institucional. Articuladamente, uma avaliação das escolas de um sistema se faz necessária para que se possa dimensionar a evolução de experiências, apreciação de tendências e generalização de iniciativas que possam incrementar o processo de aprendizagem dos alunos. (p.14)

Os estudos sobre a adoção da progressão continuada e o SARESP abordam as medidas do ponto de vista macro, tratando das medidas enquanto políticas públicas, analisando os processos de implantação e/ou implementação, uso dos resultados pelos gestores, constituindo-se em estudos que analisam documentos, relatórios, entrevistam gestores e administradores do sistema, analisam dados estatísticos e as diretrizes da política (OLIVEIRA, 1998; MACHADO, 2003; STEINVASCHER, 2003; BAUER, 2005) ou abordam as medidas do ponto de vista micro, do interior das escolas, caracterizando, muitas vezes, estudos de caso, pesquisas de cunho etnográfico, que envolvem os profissionais das escolas, alunos e pais (FELIPE, 1999; KAWAUCHI, 2001; ARCAS, 2003; BERTAGNA, 2003; BARBOSA, 2005; JEFFREY, 2006).

Tanto as pesquisas com um caráter macro, quanto aquelas com um caráter micro vêm contribuindo enormemente para a reflexão em relação à progressão continuada e ao SARESP. Além disso, o cruzamento das conclusões a que chegam essas pesquisas permite o delineamento de um panorama geral a respeito das mesmas.

A tarefa a que esta pesquisa se propôs foi de identificar como as duas medidas estão incidindo sobre a avaliação escolar. O desafio torna-se um pouco maior quando pensamos que essas políticas atingem toda a rede de ensino paulista. Ao voltar o olhar para as práticas avaliativas escolares, fatalmente cairíamos no estudo de caso, pois um pesquisador sozinho não teria condições de fazer uma pesquisa num universo mais amplo de escolas. Por outro lado, aspira-se a um trabalho que possa ser revelador, ao mesmo tempo, do que ocorre dentro das escolas, mas que permita contemplar, ao menos em parte, a diversidade da rede pública estadual de ensino. 
Propusemo-nos a realizar uma pesquisa qualitativa, cuja abordagem exige "que o mundo seja examinado com a idéia de que nada é trivial, que tudo tem potencial para constituir uma pista que nos permita estabelecer uma compreensão mais esclarecedora do nosso objeto de estudo" (BOGDAN e BIKLEN, 1994, p. 49).

O estudo abrangeu um grupo de escolas que estão jurisdicionadas a uma determinada região administrativa da Secretaria de Estado de Educação, denominada Diretoria Regional de Ensino (DRE).

Quatro Diretorias Regionais de Ensino do Estado de São Paulo foram consultadas sobre a possibilidade de realização da pesquisa com o universo de suas escolas. Apenas a Dirigente Regional de Ensino de uma delas respondeu positivamente. Assim, é nessa DRE que a pesquisa foi realizada. O fato da equipe da DRE estar disponível para a pesquisa, por um lado, facilitou meu trânsito nas escolas e mesmo entre os técnicos da Diretoria, o que foi bastante conveniente; por outro lado e, certamente o mais importante, sugere também que há, nessa DRE, interesse por parte da equipe dirigente em conhecer melhor e com rigor o que pensam e como atuam os profissionais que fazem as traduções das diretrizes e orientações emanadas dos órgãos centrais aos professores.

Para coletarmos as informações sobre a progressão continuada e o SARESP e suas implicações na avaliação escolar escolhemos, dentre os profissionais da escola, o professor coordenador (PC). A escolha desse profissional se deu pelo papel que desempenha na escola, coordenando o trabalho pedagógico e, consequentemente, orientando os professores e alunos em relação à avaliação da aprendizagem e ao uso dos resultados do SARESP pela escola.

A importância do professor coordenador deve ser destacada pelas ações desenvolvidas pela Secretaria de Educação que, desde a criação dessa função na estrutura escolar, vem dando relevância a sua ação na formação continuada dos professores. É essa ação formadora dos professores que torna o professor coordenador, no cotidiano escolar, o promotor das mudanças enfatizadas na política educacional adotada pela Secretaria de Educação. Programas de formação continuada foram desenvolvidos com foco no trabalho dos gestores escolares e, em especial, dos professores coordenadores, tais como Circuito Gestão (20002001), Ensino Médio em Rede (2004-2006), Pró-gestão (2006-2007) ${ }^{7}$, além das orientações

\footnotetext{
${ }^{7}$ Vale lembrar que todos esses programas de formação continuada tiveram como conteúdos tanto a progressão continuada como o SARESP, portanto, voltados para a discussão da avaliação escolar.
} 
periódicas dadas a esses profissionais em relação ao SARESP, nos momentos de aplicação, também são feitas orientações mais procedimentais, e na análise dos resultados, geralmente realizadas nos momentos de planejamento escolar. Nas DRE também são feitas orientações quanto à avaliação da aprendizagem, aos processos de recuperação e ao trabalho pedagógico como um todo.

Portanto, a função de professor coordenador vincula-se diretamente ao trabalho pedagógico e, consequentemente, às orientações e ao acompanhamento das práticas avaliativas. Tem-se clareza de que o professor coordenador não realiza a ação pedagógica na prática, tarefa essa que cabe aos professores, mas no universo de profissionais que atuam próximos da sala de aula é ele que está num local privilegiado, já que é seu objeto de trabalho a ação didática do professor, tornando-se, assim, um informante privilegiado de como essas práticas se processam no interior das escolas.

Por outro lado, deve-se ter clareza de que este estudo se assentou não sobre as práticas avaliativas desenvolvidas pelos professores em sala de aula, mas sim sobre o discurso que os professores coordenadores emitiram a respeito dessas práticas e sua opinião sobre como a progressão continuada e o SARESP vêm incidindo sobre as práticas avaliativas desenvolvidas pelos professores.

Num primeiro momento aplicou-se um questionário a todos os professores coordenadores que atuam em escolas que oferecem Ensino Fundamental da DRE pesquisada. Apesar de o SARESP ser realizado em todas as escolas públicas da rede estadual, a progressão continuada é uma medida que incide apenas sobre o Ensino Fundamental. Como nosso interesse era investigar realidades em que ambas as medidas coexistem, os professores coordenadores de escolas que atendem exclusivamente o Ensino Médio não foram abrangidos pelo estudo, assim como os professores coordenadores do período noturno, já que não há Ensino Fundamental neste turno ${ }^{8}$.

Tanto a adoção do regime de progressão continuada quanto o SARESP são medidas que potencializam alterações na dinâmica do trabalho na escola. Os documentos oficiais que

\footnotetext{
${ }^{8}$ Importante informar que até 2007 , ano em que foram aplicados os questionários aos professores coordenadores, havia professores coordenadores do diurno e do noturno. A partir de 2008, por mudança na legislação, os professores coordenadores deixaram de atuar por turno (diurno ou noturno) e passaram a atuar por modalidade de ensino (Fundamental ou Médio).
} 
implantam e implementam essas medidas definem objetivos que remetem às mudanças que estas pretendem ensejar. A hipótese que levantamos é que: devido à abrangência e as alterações provocadas por ambas medidas, estas geraram mudanças nas práticas avaliativas e tanto a progressão continuada quanto o SARESP desestabilizaram os princípios que, de modo dominante, norteavam a avaliação escolar, gerando uma pluralidade de situações que vão desde práticas mais formativas de avaliação até práticas que procuram, sob novas roupagens, manter a seleção e a exclusão. Dessa forma, consideramos que mudanças se processaram sob o efeito dessas políticas nas práticas avaliativas escolares, no entanto, fazse necessário identificar que mudanças são essas.

Portanto, os objetivos dessa pesquisa são:

- Identificar e analisar, na opinião dos professores coordenadores, eventuais alterações ocorridas na avaliação escolar, induzidas pela implantação da progressão continuada.

- Identificar e analisar, na opinião dos professores coordenadores, eventuais repercussões do SARESP na avaliação escolar.

- Apreender características e tendências da avaliação escolar que vêm se delineando em escolas de uma Diretoria Regional de Ensino da rede estadual paulista, após a implantação da progressão continuada e do SARESP.

Com a consecução desses objetivos pretende-se contribuir para a compreensão de impactos resultantes de mudanças nas concepções e práticas de avaliação nas escolas e, ainda, com reflexões sobre a natureza dessas mudanças e tendências futuras.

Como já foi mencionado, este estudo se caracteriza como uma pesquisa qualitativa, que se utilizou, inicialmente, de um questionário respondido por professores coordenadores de escolas que oferecem Ensino Fundamental jurisdicionadas a uma DRE. Após a leitura e análise das respostas dos questionários foram entrevistados onze professores, objetivando aprofundar os dados coletados nos questionários e aprofundar a busca de respostas para as questões de pesquisa. Procuramos, nas entrevistas, contemplar professores coordenadores que atuam em escolas com diferentes segmentos, ou seja, exclusivamente no ciclo I ou no ciclo II.

A tese está estruturada introdução, três capítulos e as considerações finais. O primeiro capítulo apresenta um panorama da progressão continuada na rede pública estadual, desde sua implantação até os dias de hoje. Foi registrada uma síntese dos principais estudos em torno da 
temática dos ciclos e da progressão continuada, procurando situar essa medida no âmbito dos estudos acadêmicos.

O segundo capítulo aborda o SARESP, indicando seus principais objetivos e características, bem como destacando mudanças que se processaram durante sua existência. São apresentados os principais estudos acadêmicos em torno deste tema e uma discussão a respeito da avaliação de sistemas no Estado de São Paulo.

O terceiro capítulo apresenta a pesquisa de campo, situando o objeto de pesquisa em seu contexto, os procedimentos de pesquisa, a coleta de dados, as análises dos questionários e das entrevistas realizadas com os professores coordenadores. Além disso, destacam-se as revelações obtidas com a pesquisa, procurando confirmar ou negar a hipótese levantada neste estudo, traçando um panorama do que vem ocorrendo nas escolas de uma DRE, a partir das impressões dos professores coordenadores em relação às práticas avaliativas, após mais de uma década de progressão continuada e SARESP.

Nas considerações finais apresentam-se as conclusões que puderem ser evidenciadas na pesquisa e as contribuições deste estudo para o campo da avaliação educacional e, particularmente, para as políticas que tratam da avaliação no estado de São Paulo. Procurouse, ainda, iluminar o caminho de novas pesquisas que visem aprofundar o tema e trazer maiores contribuições sobre o mesmo. 


\section{Capítulo I - PROGRESSÃo CONTINUADA NA REDE ESTADUAL PAULISTA}

O propósito deste capítulo é apresentar, no primeiro item, um panorama da progressão continuada na rede de ensino do estado de São Paulo, desde sua implantação até os dias de hoje. No item seguinte apresentamos uma síntese dos principais estudos em torno da temática dos ciclos e da progressão continuada, procurando situar essa medida no âmbito dos estudos acadêmicos.

\subsection{Trajetória histórica}

Ao buscarmos as origens da progressão continuada retornaremos ao século 20, quando nas décadas iniciais, os altos índices de reprovação e, consequentemente, evasão preocupavam educadores e políticos daquela época. Encontramos na produção de Barretto e Mitrulis (1999) e Mainardes (2001) sistematizações importantes sobre a trajetória das iniciativas que foram desenvolvidas pelos sistemas de ensino para o enfrentamento da reprovação e da evasão.

Essa preocupação também se evidenciava no estado de São Paulo como demonstraram Barretto e Mitrulis ao afirmarem que:

Desde os anos 20, educadores de renome e dirigentes do ensino reconheciam o fraco desempenho da escola brasileira e a gravidade da situação. $\mathrm{Na}$ Conferência Interestadual de Ensino Primário, realizada em 1921, Oscar Thompson, Diretor Geral do Ensino do Estado de São Paulo, preconizava como medida adequada a "promoção em massa." (1999, p. 29)

Naquele momento a promoção em massa era considerada como uma medida adequada, pois resolveria os problemas gerados pelos altos índices de reprovação e evasão. No entanto, o debate em torno dessa questão permaneceu entre pesquisadores e dirigentes de ensino e nos anos 1950 "já se tinha clareza de que a manutenção de uma escola fundamental seletiva era um dos obstáculos ao desenvolvimento social e econômico do país" (BARRETTO E MITRULIS, 1999, p.31). 
As autoras mostram ainda que as idéias em torno da promoção automática ou de uma progressão continuada eram discutidas, defendidas ou criticadas por vários pesquisadores, dentre eles citam-se o sociólogo Luís Pereira, o psicólogo Dante Moreira Leite e o educador Almeida Júnior. Este último, em Congresso realizado em 1956 na cidade de Ribeirão Preto, no Estado de São Paulo, revelava uma preocupação com a adoção da promoção automática e enfatizava a importância de um conjunto de medidas que reestruturassem a educação paulista:

Entendia o educador que nem a "promoção em massa", nem a "promoção por idade" ao estilo adotado pela Inglaterra, nem a "promoção automática" convinham de pronto ao caso brasileiro. Impunha-se preparar com antecedência o "espírito" do professorado a fim de obter sua adesão e precaver-se adotando medidas preliminares, sem as quais não se lograria avançar em relação ao assunto: modificar a concepção vigente de ensino primário, rever programas e critérios de avaliação, aperfeiçoar o professor, e aumentar a escolaridade primária para além dos quatro anos, assegurando o cumprimento efetivo da obrigatoriedade escolar (idem, p. 30).

As preocupações de Almeida Júnior indicam que a simples eliminação da reprovação não resolveria, por si, o problema do fracasso escolar. Para tanto seria necessária uma mudança mais ampla e que considerasse como fundamental a adesão do professorado, pois sem sua compreensão e colaboração a medida estaria fadada ao insucesso.

Durante os anos 1960 no estado de São Paulo ocorreram algumas iniciativas no sentido de criar condições que possibilitassem a implantação da progressão continuada. Mas foi somente no final da década de 1960 e começo dos anos $1970^{9}$ que houve uma iniciativa de reorganização curricular:

[...] a reorganização do currículo da escola primária em dois ciclos: o nível I, constituído pelas $1^{\mathrm{a}}$ e $2^{\mathrm{a}}$ séries, e o nível II, pelas $3^{\mathrm{a}}$ e $4^{\mathrm{a}}$ séries, com o exame de promoção somente na passagem do $1^{\circ}$ para o $2^{\circ}$ nível e ao final deste. As notas deveriam ter caráter exclusivamente classificatório para fins de reagrupamento dos alunos em classes no ano seguinte. A promoção de um nível para outro far-se-ia mediante o alcance de mínimos pré-fixados, sendo os alunos reprovados reunidos em classes especiais de aceleração. Os professores eram subsidiados com um programa mínimo para cada nível, que poderiam aprofundar em amplitude e escopo de acordo com suas possibilidades e desenvolver segundo metodologias que julgassem as mais apropriadas. Partia-se do pressuposto que a essência da mudança era o compromisso político com a democratização do ensino e a implantação de reformas estruturais que dessem ao magistério as condições necessárias para buscar caminhos possíveis (BARRETTO E MITRULIS, 1999, p. 35).

\footnotetext{
${ }^{9}$ Segundo Mainardes (2001) a reorganização curricular da escola primária paulista foi chamada de organização em níveis e vigorou de 1968 a 1972.
} 
Apesar dos esforços realizados na época pelos idealizadores da proposta, esta não se consolidou na prática devido à reação de setores conservadores da sociedade e do próprio ensino. Somente na década de 1980 a idéia de reorganização curricular e eliminação da reprovação seriam efetivadas na prática, com a adoção do ciclo básico de alfabetização.

Na rede estadual paulista o ciclo básico passou a vigorar a partir de 1984, sendo extinto somente em 1998, com a adoção da progressão continuada e a reorganização do ensino. A implantação do ciclo básico em São Paulo procurava, como alertara Almeida Júnior décadas atrás, não apenas eliminar a reprovação da $1^{\mathrm{a}}$ para a $2^{\mathrm{a}}$ série como implementar algumas medidas visando assegurar a aprendizagem dos alunos:

O ciclo básico não previa uma redução dos conteúdos trabalhados nos dois primeiros anos de escolarização. Possibilitava antes maior flexibilidade de organização curricular quanto ao agrupamento de alunos, à revisão de conteúdos programáticos e à utilização de estratégias de aprendizagem mais condizentes com a heterogeneidade da clientela, bem como em relação à escolha de critérios de avaliação. A proposta do ciclo básico veio por vezes acompanhada de atendimento paralelo - em grupos menores - dos alunos com maiores dificuldades; de incentivo à permanência dos professores mais experientes nas séries iniciais e de suprimento de material pedagógico específico, embora tais medidas nem sempre tivessem perdurado nas redes de ensino (IDEM, p. 37).

Outro aspecto muito ressaltado pela proposta do ciclo básico era a necessidade de mudança da avaliação, enfatizando a necessidade de uma avaliação diagnóstica. Nesse caso, como evidenciam Barretto e Mitrulis, "a intenção é que a avaliação forneça os elementos necessários à melhoria da qualidade do ensino, deixando de funcionar como uma arma contra o aluno, um exercício de poder sobre ele" (ibidem, p. 38).

Mainardes (2001), baseando-se em estudos que avaliaram o ciclo básico em São Paulo, conclui que:

O Ciclo Básico representou um avanço na democratização do ensino, ainda que esse avanço tenha ficado aquém das expectativas das entidades de classe, dos profissionais da Rede, do nível de qualidade do ensino a que os alunos têm direito e do que o Estado deveria ter conseguido. [...] ao contrário de promover a integração, propiciou a segmentação, inclusive da avaliação dos alunos, havendo ausência da prática de avaliação. Além disso, observouse uma maior permanência dos alunos na rede, embora não tenha alcançado plenamente seus propósitos (p. 45).

Portanto, podemos considerar que apesar de haver um conjunto de ações para implantação e implementação do ciclo básico em São Paulo e de uma vigência relativamente 
longa da medida, 14 anos, a avaliação desta política indicou problemas importantes ao se pensar na ampliação dos ciclos e da progressão continuada para todo Ensino Fundamental.

A partir de 1998 a Secretaria de Estado de Educação, por meio da Resolução n 4/98, organizou o Ensino Fundamental em dois ciclos: $1^{\circ}$ ao $4^{\circ}$ ano, ciclo I; e $5^{\circ}$ ao $8^{\circ}$ ano, ciclo II. A reprovação dos alunos no regime de progressão continuada somente poderia ocorrer em duas circunstâncias: ao final de cada ciclo, caso o aluno não atingisse o aproveitamento esperado, ou por freqüência inferior a $75 \%$ do global, ao final de cada ano letivo.

A adoção dessa medida encontrava respaldo na LDB, conforme explicitado no artigo 32:

"§ $1^{\circ}$ - É facultativo aos sistemas de ensino desdobrar o ensino fundamental em ciclos".

"§ $2^{\circ}$ - Os estabelecimentos que utilizam progressão regular por série podem adotar no ensino fundamental o regime de progressão continuada, sem prejuízo da avaliação do processo de ensino-aprendizagem, observadas as normas do respectivo sistema de ensino".

Fundamentado no artigo supracitado, o Conselho Estadual de Educação (CEE) do estado de São Paulo publicou, em julho de 1997, a Deliberação n 9 e a Indicação nº 8, ambas instituindo na rede pública a organização do ensino em ciclos e o regime de progressão continuada. A partir das recomendações do CEE explicitadas na Deliberação no 9/97 e Indicação no 8/97, em janeiro de 1998, a Secretaria de Estado da Educação (SEE) emitiu a Resolução $\mathrm{n}^{\mathrm{o}} 4$, determinado a vigência da medida em todas as escolas estaduais de Ensino Fundamental.

Os documentos emanados dos órgãos normativos do sistema de ensino estadual ressaltavam a necessidade de manutenção dos processos avaliativos no interior dos ciclos, enfatizando que fosse atribuído um caráter formativo à avaliação da aprendizagem, já que o caráter seletivo e classificatório da avaliação, que predominava na maioria das escolas, perdia sentido nesse novo cenário:

A avaliação deixa de ser um procedimento decisório quanto à aprovação ou reprovação do aluno. A avaliação é o fato pedagógico pelo qual se verifica continuamente o progresso da aprendizagem e se decide, se necessário, quanto aos meios alternativos de recuperação ou reforço. [...] Esta avaliação contínua em processo é o eixo que sustenta a eficácia da progressão continuada nas escolas (INDICAÇÃO CEE nº 8/97). 
Ao tratar da questão da avaliação nos ciclos, Sousa (2000) comenta que essa forma de organizar o ensino e a adoção da progressão continuada possibilita uma ressignificação da finalidade da avaliação:

A avaliação seja entendida como um processo inerente à ação educacional é uma atividade contínua, atendendo a diferentes funções. No sistema de progressão continuada, a função classificatória perde importância, impulsionando a busca do cumprimento de funções nucleares da avaliação, capazes de promover sentido ao processo de ensino e de aprendizagem. Têm sido enfatizadas como funções da avaliação, na literatura da área, o diagnóstico, a retroinformação e o favorecimento do desenvolvimento dos alunos caracterizando-se, essencialmente, como uma prática que tem por fim apoiar e orientar os processos de planejamento e mudança (p. 41).

De certa forma, o impacto dessa medida nas escolas foi antecipado pelo CEE nas recomendações contidas na Indicação 8/97. Uma dessas preocupações evidencia-se logo no início da indicação onde se afirma que "um ponto de resistência a uma mudança desta magnitude poderia ser creditado aos profissionais da educação e às famílias diretamente envolvidas". Em outra parte do documento, a preocupação com as dificuldades de implantação da medida e da resistência a ela se manifesta novamente:

Não há que se iludir [...] de que não haverá resistências sob alegação apressada em sem fundamento de que se estará implantando a promoção automática, ou a abolição da reprovação, com conseqüente rebaixamento da qualidade do ensino. Para minimizar os efeitos perturbadores desse tipo de reação será necessário, antes de mais nada, um projeto bem estruturado, com ampla participação da comunidade e amplo apoio a toda a população (INDICAÇÃO CEE nº 8/97).

Ao refletirem sobre as políticas de ciclos no Brasil, Barretto e Sousa ressaltam, dentre as características destas políticas, a adoção da progressão continuada e a eliminação da reprovação a cada ano do Ensino Fundamental, restringindo a possibilidade de reprovação a um espaço maior de tempo. Essa proposta, inevitavelmente, coloca a avaliação no centro dessas mudanças, o que:

[...] tem sido considerado o aspecto mais desestabilizador do trabalho escolar, exatamente porque se confronta com a pedagogia do exame, lógica norteadora das rotinas e práticas escolares, bem como das expectativas de professores, alunos e pais. No limite, os ciclos põem em questão a finalidade da avaliação, que tradicionalmente tem sido associada à seleção e classificação dos alunos, tendo por finalidade decidir sobre a sua promoção ou retenção para a série subsequiente (2005, p. 674-675).

Importante lembrar que, desde a implantação da progressão continuada em 1998, não identificamos qualquer movimento de reformulação da medida por parte da Secretaria de 
Educação, não havendo, em termos legais e normativos, alteração no que foi proposto naquele momento.

\subsection{Panorama das Pesquisas Acadêmicas}

Devido ao potencial desestabilizador da progressão continuada em relação às práticas avaliativas nas escolas, sua implantação e consequentes desdobramentos despertariam a atenção dos estudiosos da temática dos ciclos e da avaliação e seria objeto de estudo de pesquisas acadêmicas. Neste item procuramos identificar pesquisas que possibilitariam construir um panorama desses mais de dez anos de vigência da progressão continuada, selecionando, a partir das principais conclusões desses estudos, elementos que possam auxiliar na análise dos dados coletados para a elaboração desta tese. Como esta pesquisa tem como recorte, no tocante a progressão continuada, o período de 1998 a 2007, limitamos a ele o levantamento realizado.

Entre 2000 e 2007 foram defendidas 58 dissertações de mestrado e 15 teses de doutorado que tiveram como objeto a progressão continuada ${ }^{10}$. Das 58 dissertações de mestrado, identificamos 35 cuja temática está relacionada a este estudo. Das 23 dissertações identificadas e que não se vinculam diretamente ao objeto desta pesquisa, 15 têm como foco a formação continuada de professores ou projetos específicos relacionados ao fluxo escolar como recuperação de ciclo, classes de aceleração, recuperação paralela e reforço ou aspectos macro da política educacional. Esclarecemos que as temáticas elencadas se vinculam ao tema da progressão continuada, entretanto, não se limitam a ele e ainda se relacionam outras questões da escola e das políticas educacionais. As demais dissertações, ao todo oito, não puderam ser consideradas neste estudo por estudarem a progressão continuada em redes de ensino de outros estados ou municípios.

Das 15 teses defendidas no mesmo período, de 2000 a 2007, nove eram pesquisas que tratavam da progressão continuada na rede estadual paulista. Três dos demais estudos se

\footnotetext{
${ }^{10}$ Disponível em http://www.uepg.br/gppepe
} 
relacionavam a outras redes de ensino e os outros três não têm como foco principal a progressão continuada.

Majoritariamente os estudos, tanto dissertações quanto teses, se caracterizam por pesquisas de natureza qualitativa, utilizando-se de análise documental, documentos oficiais produzidos pela Secretaria de Educação e outros produzidos pelas escolas, aplicação de questionários, entrevista, observação do cotidiano escolar e das práticas pedagógicas e estudos de caso. Em relação ao período estudado, os estudos se distribuem do seguinte modo:

Tabela 1 - Dissertações e Teses sobre progressão continuada defendidas no período de 2000 a 2007

\begin{tabular}{|c|c|c|c|c|c|c|c|c|c|}
\hline Ano & $\mathbf{2 0 0 0}$ & $\mathbf{2 0 0 1}$ & $\mathbf{2 0 0 2}$ & $\mathbf{2 0 0 3}$ & $\mathbf{2 0 0 4}$ & $\mathbf{2 0 0 5}$ & $\mathbf{2 0 0 6}$ & $\mathbf{2 0 0 7}$ & Total \\
\hline Dissertações & 01 & 05 & 06 & 03 & 05 & 03 & 04 & 08 & 35 \\
\hline Teses & 01 & - & 01 & 01 & 01 & 02 & 01 & 02 & 09 \\
\hline
\end{tabular}

A tabela foi elaborada com o objetivo de situar os estudos ao longo do tempo de vigência da progressão continuada. Percebemos que há um número maior de dissertações defendidas entre os anos de 2001-2002 e uma concentração em 2007, o que chama atenção, pois estava para se completar uma década de progressão continuada na rede estadual paulista. Em relação às teses podemos dizer que no período indicado ocorreu, ao menos, uma defesa a cada ano, à exceção de 2001. Essa situação nos indica que o tema vem suscitando interesse por parte de pesquisadores.

A partir de uma análise exploratória das conclusões indicadas pelos autores destes estudos procuramos identificar aspectos que são mais elencados. A recorrência de alguns deles permite-nos compreender as principais contribuições que as pesquisas trouxeram para o tema em estudo. A tabela seguinte apresenta estes dados:

Tabela 2 - Conclusões recorrentes em dissertações e teses sobre progressão continuada

\begin{tabular}{|c|l|c|c|c|}
\hline $\mathbf{N}^{\mathbf{0}}$ & \multicolumn{1}{|c|}{ Conclusão } & Dissertações & Teses & Total \\
\hline $\mathbf{1}$ & $\begin{array}{l}\text { A implantação e implementação da progressão } \\
\text { continuada desconsideraram a tradicional cultura } \\
\text { escolar e a participação dos professores. }\end{array}$ & 13 & 04 & 17 \\
\hline
\end{tabular}




\begin{tabular}{|c|l|c|c|c|}
\hline $\mathbf{2}$ & $\begin{array}{l}\text { Permanência de práticas avaliativas tradicionais, } \\
\text { não ocorrendo mudanças significativas para práticas } \\
\text { avaliativas formativas. }\end{array}$ & 12 & 02 & 14 \\
\hline $\mathbf{3}$ & $\begin{array}{l}\text { Perda da qualidade de ensino, alunos não } \\
\text { conseguem aprender. }\end{array}$ & 09 & 03 & 12 \\
\hline $\mathbf{4}$ & $\begin{array}{l}\text { Não houve uma adoção dos ciclos na prática, } \\
\text { manutenção da seriação. }\end{array}$ & 08 & 03 & 11 \\
\hline $\mathbf{5}$ & $\begin{array}{l}\text { Manutenção da possibilidade da reprovação, do } \\
\text { fracasso escolar e da exclusão no interior da escola } \\
\text { por outros mecanismos. }\end{array}$ & 08 & 02 & 10 \\
\hline $\mathbf{6}$ & $\begin{array}{l}\text { Progressão continuada potencializou a necessidade } \\
\text { de mudar a escola e de repensar práticas } \\
\text { pedagógicas e avaliativas. }\end{array}$ & 08 & 01 & 09 \\
\hline $\mathbf{7}$ & $\begin{array}{l}\text { Despreparo do professor e falta de formação } \\
\text { continuada. }\end{array}$ & 07 & 01 & 08 \\
\hline $\mathbf{8}$ & $\begin{array}{l}\text { Compreensão da reprovação como estímulo ao } \\
\text { estudo e controle do comportamento. }\end{array}$ & 04 & 03 & 07 \\
\hline $\mathbf{9}$ & $\begin{array}{l}\text { Progressão continuada favoreceu a correção de } \\
\text { fluxo, a diminuição da evasão e da repetência. }\end{array}$ & 03 & 02 & 05 \\
\hline
\end{tabular}

Alguns estudos, por suas características e aproximações com essa pesquisa, serão brevemente comentados, o que contribuirá para compreendermos o panorama sobre o que as pesquisas têm revelado e iluminarão, nos capítulos seguintes, a análise dos dados coletados neste estudo.

Em tese de doutorado defendida em 2000, José Cleber de Freitas analisa a relação entre cultura, educação e currículo presente na implantação da progressão continuada, concluindo que essa medida não se pautou por uma reorientação curricular, observando que a sua adoção pode gerar um aprofundamento das desigualdades sociais e culturais, se não houver a garantia de uma aprendizagem com qualidade para todos os alunos.

Freitas ainda critica a organização do ensino em dois ciclos, pois considera que a SEE não justifica essa opção com argumentos solidamente pedagógicos, mas vincula-se a um

\footnotetext{
${ }^{11}$ Duas dissertações e uma tese consideraram que a correção de fluxo e a diminuição da evasão e da repetência são avanços importantes proporcionados pela adoção da progressão continuada. Por outro lado, uma dissertação e uma tese consideraram ser apenas este o objetivo central da política de ciclos e progressão continuada implantada no Estado de São Paulo.
} 
objetivo político maior que era, na ocasião, a municipalização do ensino ${ }^{12}$. Outra crítica feita pelo pesquisador, a partir dos dados coletados com os professores, é que o objetivo da SEE ao implantar essa medida estava centrado na redução dos índices de evasão e repetência e na economia de recursos financeiros.

Em 2000, outra pesquisa que contribui para a reflexão em torno da progressão continuada é a de Rita de Cássia Silva. Sua investigação se pautou por entrevistas com professores dos anos iniciais do Ensino Fundamental e professores especialistas que trabalham nas séries finais. Nas entrevistas, a autora procurou identificar os saberes e crenças de professores da escola pública paulista a respeito da reprovação escolar no contexto da implantação da progressão continuada.

Silva concluiu que, apesar de reconhecerem os efeitos nocivos da reprovação escolar, muitos professores ainda consideram que ela pode contribuir para sinalizar a necessidade de maior esforço do aluno e/ou controlar seu comportamento inadequado. Os professores, na maioria das entrevistas, desvalorizam e criticam a progressão continuada, pois consideram que ela empobrece as exigências de domínio dos conteúdos escolares e desvaloriza o rendimento escolar do aluno. Os professores entrevistados também criticam a forma de implantação da progressão continuada, sem o adequado envolvimento dos professores, desconsiderando seus saberes e crenças.

Eike Frehese (2001), em dissertação de mestrado, chega a conclusões que se aproximam das de Freitas e Silva. Sua pesquisa visou apreender os significados que os professores atribuem às relações pedagógicas que se configuram no contexto da política de progressão continuada, marcadas pela mudança da rotina diária profissional. Para tanto, desenvolveu estudo de caso e concluiu que a principal dificuldade enfrentada, na opinião dos professores, é o momento que estavam vivenciando, em contraposição a um passado idealizado, ou seja, a escola não é mais o que era e os alunos já não são mais aqueles do passado.

\footnotetext{
12 O processo de municipalização do Ensino Fundamental no Estado de São Paulo intensificou-se após 1996, com a promulgação do Decreto $n^{\circ} 40.673 / 96$, posteriormente alterado pelo Decreto $n^{\circ} 40.889 / 96$, que instituiu o Programa de Ação de Parceria Educacional Estado-Município para o atendimento ao Ensino Fundamental. Esse movimento foi impulsionado pela promulgação da Lei 9.394/96 e do Fundo de Manutenção e Desenvolvimento do Ensino Fundamental e de Valorização do Magistério (Fundef). A organização do ensino em dois ciclos facilitaria a municipalização devido à divisão que gerou no Ensino Fundamental ofertado em escolas distintas, facilitando a municipalização ao menos das escolas até a $4^{\mathrm{a}}$ série.
} 
Ao refletir sobre a democratização do ensino e sua relação com a progressão continuada, Frehese conclui que o discurso da democratização do ensino é avaliado positivamente pelos professores, mas sua concretização gera muitas controvérsias. Segundo a autora, os problemas levantados a partir da implantação da progressão continuada devem ser compreendidos enquanto questões conjunturais e não como obstáculos à democratização do ensino.

Outra pesquisa, concluída em 2002, foi o estudo de caso desenvolvido por Tamara Fresia Mantovani de Oliveira, buscando identificar, descrever e discutir o embate entre as necessidades produzidas no cotidiano escolar e a implantação da progressão continuada. A pesquisadora procurou conhecer, no âmbito das práticas escolares, os limites e as possibilidades de enfrentamento do fracasso escolar após a implementação da progressão continuada.

Por meio do discurso dos professores, Oliveira identificou que a eliminação da reprovação com a adoção do regime de progressão continuada propiciou elementos para o enfrentamento do fracasso escolar, na medida em que potencializou uma reflexão sobre as práticas avaliativas e os males provocados pela reprovação. Entretanto, ressalta que "a maioria dos profissionais da escola atribuía a não-reprovação advinda com a progressão continuada um obstáculo para o desenvolvimento de seu trabalho em sala de aula [...]" (grifos da autora). (OLIVEIRA, 2002, p. 139).

Oliveira conclui, com sua pesquisa, que:

$\mathrm{Na}$ aproximação com a cultura da escola evidenciou-se a distância entre o discurso do "reformador" [...] e o discurso produzido na escola [...] que revelaram conflitos latentes e dificuldades para tornar o real o ideal presente na proposta do regime de progressão continuada (2002, p.139).

O estudo de Claudia Cristina Fiorio Guilherme (2002) teve como foco os profissionais da educação que atuam em escolas que atendem o Ciclo I (professores, professores coordenadores e supervisores de ensino). Em entrevistas realizadas com uma amostra desses profissionais vinculados a oito escolas públicas de município do interior do estado de São Paulo, Guilherme procurou caracterizar a implementação dos ciclos e da progressão continuada nas escolas e as várias formas de resistência e reinterpretação praticadas pelos professores ao lidarem com os ciclos. 
Em suas conclusões a crítica recai sobre o processo de implantação e implementação da progressão continuada pelos gestores do sistema de ensino que, neste processo, desconsideraram a participação dos professores. Também evidencia a necessidade de se ouvir os professores e que se leve em conta a complexidade da cultura e das relações escolares na implementação das políticas educacionais.

Lygia de Sousa Viégas (2002), em pesquisa de mestrado, objetivou evidenciar as concepções de educadores acerca da progressão continuada e as mudanças que esta política trouxe na realização do trabalho docente. A partir de estudo de caso concluiu que a implantação da progressão continuada não veio acompanhada de condições objetivas para o enfrentamento dos fatores que, de fato, produzem a má qualidade do ensino. Segundo a autora os alunos deixaram de ser reprovados, mas estão apenas passando pela escola, sem a devida aprendizagem. Portanto, considera que a exclusão que ocorria no interior das escolas pela reprovação permanece com uma nova roupagem, já que não se garante a efetiva aprendizagem, pois "o fracasso na escolarização de alunos das escolas públicas paulistas ficou sutilizado, tornando-se imperceptível ao olhar apressado que se ativer apenas as estatísticas oficiais" (2002, p. 167).

Andrea Steinvascher (2003) realizou pesquisa em que buscou avaliar a implantação da progressão continuada, procurando apreender possibilidades e limites dessa política. A partir da análise de documentos da SEE e do CEE a autora identificou os pressupostos e justificativas de ambos os órgãos no tocante a adoção do regime de progressão continuada e organização do ensino em ciclos. Também levantou e analisou as estratégias e subsídios criados pela SEE para viabilizar a proposta, sobretudo para o envolvimento dos educadores. A autora analisou, ainda, como os sindicatos e associações de profissionais da educação do estado de São Paulo interpretaram e se posicionaram em relação à progressão continuada e ao seu processo de implantação.

Steinvascher (2003) afirma, assim como outras pesquisas também evidenciaram, que:

[...] a implantação da progressão continuada tem o potencial de estabelecer um movimento no sentido de repensar a escola, podendo fortalecer o compromisso entre os educadores, alunos e pais, com a aprendizagem de todos. A definição deste processo como "movimento de repensar a escola" decorre da crença de que a reorganização escolar necessária para a democratização do ensino não se limita aos aspectos estruturais, mas aos valores que dão sustentação a esta organização. "Repensar a escola" significa, assim, questionar sua finalidade: Para quê escola? Não se trata, portanto, de um processo simples, fácil, nem rápido; é um movimento que 
deve envolver tanto os educadores como toda a comunidade escolar, caracterizando-se como um espaço de tensões e debates (p.11).

Com esta afirmação, Steinvascher explicita a complexidade de se modificarem práticas arraigadas na cultura escolar, pois elas não significam apenas um modo de se fazer, mas uma maneira de se pensar e de se conceber o mundo e a sociedade. Ao analisar o processo de formulação e de implantação, a autora concluiu que o professor não foi considerado como sujeito fundamental dessa política, que a ausência de reorientação curricular impõe, somente à escola, a responsabilidade pela melhoria da qualidade de ensino e que a ação da SEE limitou-se a distribuição de materiais de orientação.

Steinvascher, no tocante às entidades pesquisadas, conclui que as críticas em relação à progressão continuada, de modo geral, concentram-se na forma autoritária adotada pelos gestores em sua implantação e na falta de subsídios e condições de trabalho, que acabam por limitar o potencial da proposta. Aponta, a guisa de conclusão, que:

A cultura da seletividade, a partir da qual se concebe que nem todos os alunos são capazes ou merecem atingir o sucesso, precisa ser abertamente discutida e enfrentada, visto que, esta pode permear as práticas pedagógicas num sistema com ou sem possibilidade de reprovação ao final de cada ano de escolarização (2003, p. 166).

Em síntese, os estudos que apresentamos sugerem que a progressão continuada tem uma contribuição no sentido de favorecer uma concepção de avaliação formativa, processual, voltada para a garantia da aprendizagem. Entretanto, esse potencial transformador das práticas avaliativas e demais práticas escolares fica comprometido pela execução de uma política educacional que exclui seus profissionais do debate sobre a proposta e oferece poucos subsídios para um maior entendimento do que seja a progressão continuada. Obviamente que a questão é mais complexa que isso, mas enfrentar a resistência dos profissionais da educação, abrindo o diálogo com a rede, e proporcionar formação são elementos que podem auxiliar na compreensão sobre os ciclos e a progressão continuada.

Regiane Bertagna (2003), em tese de doutorado, acompanhou o desenvolvimento da proposta de regime de progressão continuada em uma escola da rede pública estadual no município de Campinas. A escola em questão ofertava Ensino Fundamental da $1^{\mathrm{a}}$ a $4^{\mathrm{a}}$ série (Ciclo I) e por meio de observação direta e entrevistas com os profissionais da escola e os alunos procurou identificar os limites e as possibilidades da progressão continuada. A autora enfatiza que "o acompanhamento das práticas escolares torna-se essencial para captar as mudanças efetivas no cotidiano escolar, e não apenas as proclamadas" (p. 4). 
Mais do que identificar a reação de professores e alunos em relação ao regime de progressão continuada e revelar as resistências, permanências e adaptações que se processam no cotidiano escolar em função, fundamentalmente, da eliminação da reprovação, o estudo de Bertagna analisa a progressão continuada, problematizando essa medida no bojo da discussão a respeito dos ciclos. $\mathrm{O}$ discurso da progressão continuada vem alicerçado na concepção de organização do ensino em ciclos, entretanto, Bertagna enfatiza que a medida implantada pela SEE se reduz apenas a eliminar a reprovação. A autora comenta que o debate se concentra na aprovação/reprovação, não incidindo sobre a questão da organização do ensino em ciclos, o que representaria uma discussão sobre a concepção de educação e de ensino que estão pautados e do tipo de formação que os ciclos propõem. De certa forma, Bertagna conclui que a discussão em torno da progressão continuada, por mais que enfatize outra perspectiva avaliativa, com caráter mais formativo, tira o foco da questão central que é a dos ciclos:

Ao se revelar desta forma a organização escolar e em não se realizando o debate sobre a mesma, sobre os seus fins e sobre a estrutura social com a qual ela se compromete de forma mais ampla, e mais especificamente, sobre a possibilidade contida na idéia de ciclos; não criando ou dando condições estruturais adequadas para as instituições escolares e seus profissionais desenvolverem um trabalho efetivo, a potencialidade que poderia conter esta nova organização escolar [...] acabou não se efetivando e promovendo simplesmente a aprovação automática dos alunos dentro dos ciclos (BERTAGNA, 2003, p. 450).

Ainda segundo Bertagna, a progressão continuada se opõe à seletividade realizada pela escola caracterizada pela aprovação/reprovação. Entretanto, os dados de pesquisa revelam que ela não está conseguindo cumprir com essa função na medida em que:

[...] carrega consigo não somente as marcas da seletividade da escola - mas através desta, revela as desigualdades escolares e sociais. A avaliação neste caso ajudou a explicitar como no interior das escolas se constroem, muitas vezes, dissimuladamente tais desigualdades que são originárias da estrutura social na qual vivemos e, remete toda a discussão para os fins da educação dentro dessa estrutura, ficando incipiente as discussões focadas somente em alguns aspectos da estrutura escolar, pois as suas explicações e compreensões s colocam fora deste ambiente. (grifo da autora) (2003, p.457).

Portanto, o principal limite apontado por Bertagna é o de como, na prática, opera a seletividade no regime de progressão continuada, tornando-se necessário enfrentar as contradições da realidade em que vivemos, podendo, assim, entender a sociedade e a escola e impulsionar ações para a transformação de ambas. Para a autora a ressignificação da avaliação 
deve ocorrer para além de seus aspectos formais, pois na avaliação informal feita pelos professores a seletividade e exclusão mantêm-se presentes.

Os estudos de Adriana Patrício Delgado (2004) e Roger M. Quadros de Souza (2004) tiveram como foco o regime de progressão continuada procurando identificar no cotidiano escolar como os profissionais da educação estão assimilando essa medida e que mudanças ela está promovendo nas práticas escolares. Ambas as pesquisas se caracterizaram como estudos de cunho qualitativo e utilizaram entrevistas como principal instrumento para a coleta de dados.

Delgado concluiu que permanece a lógica da seriação e os instrumentos de avaliação são utilizados com vistas à seleção e classificação, demonstrando que, na fala dos entrevistados está presente o desejo pelo retorno da reprovação. Identificou, por meio do estudo realizado, que o grupo de professores, além de necessitar de orientação em relação à progressão continuada, revelou descrença nas intenções das reformas educativas propostas pela SEE. Destacou que houve mudanças nas práticas avaliativas e educativas, mas que estas não foram suficientes para alterar concepções e hábitos instituídos na escola pesquisada. "Foi perceptível a não efetivação da cultura ciclada pela permanência da cultura seriada" (DELGADO, 2004, p. 153).

Conclui Delgado que ao invés da progressão continuada e a organização do ensino em ciclos se apresentarem como medidas de enfretamento do fracasso escolar acabaram sendo percebidas como causadoras do fracasso da escola por não conseguirem promover a efetiva aprendizagem de todos os alunos, induzindo, segundo os professores, ao rebaixamento do nível de ensino e de aprendizagem:

É nessa contradição que parece que tenha esvaziado o argumento de sustentação da implantação dos ciclos e da progressão continuada, qual seja, a democratização da escola pela superação das práticas seletivas e excludentes promovidas, sobretudo pela avaliação. [...] os ciclos e a progressão estão sendo entendidos como causas do fracasso do sistema educacional, tornando-se necessário, então, para muitos, combatê-los pelo retorno da seriação e reprovação (IDEM, p.146).

Roger M. Quadros de Souza (2004) constatou que a adoção do regime de progressão continuada, no universo pesquisado, promoveu o enfraquecimento da autoridade pedagógica. Segundo ele, os dois pilares dessa autoridade que ficaram enfraquecidos foram: o reconhecimento do professor como legítimo portador do conhecimento, que ocorreu devido à desvalorização do conhecimento pelos alunos e pela falta de apoio institucional, referindo-se 
aos órgãos gestores do sistema, no desenvolvimento da atividade docente e o enfraquecimento do poder do professor sobre a decisão da progressão escolar.

Para Souza alguns dos principais conflitos gerados pela progressão continuada situamse na forma como foi implantada e na ausência de uma efetiva política de implementação. $\mathrm{O}$ autor considera que "a origem do conflito se localiza no processo de implantação de um novo arbitrário cultural dominante, imposto pela reforma nas escolas públicas do estado de São Paulo, e o arbitrário cultural dominante já consolidado no capital cultural e nos habitus que engendram as práticas dos professores" (SOUZA, 2004, p. 231).

O autor identificou que muitos professores ainda vêem a reprovação como uma forma de garantir a qualidade da escola, como forma de se valorizar os conteúdos, de desenvolver nos estudantes características como seriedade, responsabilidade, entre outras atitudes. Isso revela que, apesar da existência da progressão continuada na rede pública estadual, desde 1998, a perspectiva da avaliação como instrumento de controle e de poder dos professores se mantém fortemente presente e desejada.

Essa permanência latente de concepções e práticas mais tradicionais e que deveriam ser, ao menos, problematizadas com a progressão continuada, é compreendida por Souza como sendo gerada pela ausência de participação dos professores na implantação dessa política:

[...] a ação e as práticas docentes não podem ser reduzidas à visão de que os professores encontram-se acomodados ou que não se importam com os alunos ou com a escola ou então de que não aceitam mudanças [...] percebese que a escola está em "ebulição" e é marcada por conflitos e contradições [...] e que os professores estão mobilizados na defesa daquilo que eles entendem como escola pública de qualidade para atender ao seu alunado (2004, p. 239).

Renato Zanini (2006) desenvolveu pesquisa centrada em professores de matemática, procurando revelar como estão compreendendo e incorporando o trabalho no Ensino Fundamental organizado em ciclos com progressão continuada. O que ele constatou é que "existe insatisfação e resistência, por parte dos professores, com relação aos aspectos teóricos e práticos presentes no regime de progressão continuada" (p. 94). Por outro lado, a insatisfação e a resistência "fazem com que os professores compreendam, incorporem os significados atuais da profissão e, com isso, atribuam novos significados às atividades docentes" (p.95). 
O estudo de Alessandra Hauk Poliche (2006) procurou identificar as implicações da progressão continuada na avaliação da aprendizagem. Sua pesquisa evidenciou muitas críticas ao regime de progressão continuada, principalmente na forma "autoritária" como foi implantado e na ausência de orientações, por parte da SEE, sobre o mesmo. Identificou, entre os professores entrevistados, um desconhecimento dos princípios da progressão continuada e da organização do ensino em ciclos, o que tem, segundo ela, gerado distorções nas práticas avaliativas, ocasionando a promoção automática. A autora concluiu que a SEE, ao determinar a implantação da progressão continuada, "não deu o suporte necessário para os professores compreenderem as mudanças que o sistema exigia, nem os preparou para tal. O resultado é a contradição entre a proposta, seus fundamentos e princípios e a prática cotidiana" (p. 53).

Em pesquisa de doutorado, Débora Cristina Jeffrey (2006) abordou as representações de docentes sobre o regime de progressão continuada, evidenciando seus dilemas e possibilidades. Um dos dilemas apontados pela pesquisa revela que, por um lado, "a SEE procura regulamentar e legitimar o regime de progressão continuada sem indicar a base norteadora que o orienta", por outro, os professores entrevistados convivem com "duas formas de organização: a oficial, regulamentada pelas normas da SEE e a extra-oficial, constituída pelas representações dos docentes, suas experiências, convicções e incertezas" (p.208).

Jeffrey indicou que "a organização extra-oficial tem oferecido subsídios necessários para o trabalho pedagógico, o estabelecimento da relação professor-aluno e das práticas avaliativas" (2006, p. 208). A autora enfatizou que, mesmo após sete anos de vigência da progressão continuada, verificava-se a falta de uma ação efetiva por parte dos gestores do sistema em implantar e implementar essa medida, o que possibilitaria aos profissionais da educação a compreensão dos pressupostos teóricos da progressão continuada e formas de atuar - principalmente no tocante às práticas avaliativas, que se aproximem dos fundamentos contidos na organização do ensino em ciclos e no regime de progressão continuada. O que a autora evidenciou é que essa ausência de ações efetivas fazia com que os conflitos gerados pela adoção da progressão continuada fossem resolvidos por meio de ajustes que se estabeleciam nas práticas escolares, que tanto podiam provocar mudanças inovadoras como podiam apenas acomodar práticas já consolidadas ao novo contexto.

Em estudo bibliográfico no tocante às políticas de ciclos e progressão escolar, que abrangeu as produções acadêmicas de 1990 até 2002, Sousa e Barretto (2004) concluem que 
"as pesquisas registram ter sido insuficiente a preparação dos profissionais" e que "a falta de participação dos educadores no processo de formulação e de implementação da proposta é uma característica apontada em todas as pesquisas analisadas" (p. 35).

As pesquisas posteriores ao estudo feito por Sousa e Barretto reafirmam essas mesmas conclusões, mas passaram a indicar também que a SEE, apesar de não alterar a organização do ensino em ciclos e manter a progressão continuada, mesmo com as críticas apontadas pelas pesquisas anteriormente apresentadas, não propiciou um debate amplo com a rede de ensino no sentido de contemplar as críticas, de orientar os profissionais da educação, de promover o entendimento de alunos e pais, de conscientizar a sociedade em geral da importância dessa medida e do seu potencial para a democratização do ensino.

Além disso, no desenvolvimento da política educacional na rede estadual de São Paulo, nas gestões de Rose Neubauer (1995-1998 e 1999-2002), Gabriel Chalita (2002-2006), Maria Lúcia Vasconcellos (2006-2007) e mesmo na atual gestão de Maria Helena Guimarães Castro, iniciada em 2007, não se registra iniciativa mais contundente de debate, discussão ou formação que enfatize a organização do ensino em ciclos e o regime de progressão continuada.

Em 23 de junho de 2002, o então secretário de educação Gabriel Chalita afirmava em entrevista concedida ao jornal $O$ Estado de São Paulo que iria iniciar um processo de investimento no professorado, enfatizando a importância dos professores para as mudanças exigidas na organização do ensino em ciclos e no regime de progressão continuada ${ }^{13}$.

Naquela ocasião, as declarações do secretário Chalita ao referido jornal indicavam para uma revisão da progressão continuada, iniciando, nessa mesma época, um Fórum de discussão para o qual foram chamados pesquisadores da academia, entidades de classe e técnicos da SEE. Alguns dos participantes do Fórum foram: os professores universitários e pesquisadores Elba Siqueira de Sá Barretto, Clarilza Prado de Souza e Mário Sérgio Cortella; Vera Lúcia Wey, como representante da SEE, além de representantes das entidades Associação dos Profissionais do Ensino Oficial do Estado de São Paulo (APEOESP), Centro do Professorado Paulista (CPP), Sindicato de Especialistas de Educação do Magistério Oficial do Estado de São Paulo (UDEMO) e Sindicato de Supervisores do Magistério do Estado de

\footnotetext{
${ }^{13}$ Jornal O Estado de São Paulo, 23 de junho de 2002, p.A9.
} 
São Paulo (APASE). Entretanto, após a realização desse primeiro encontro do Fórum não houve prosseguimento das discussões iniciadas e nem sua ampliação para a rede de ensino. A política desenvolvida nos anos seguintes esteve centrada na formação continuada dos professores e o debate em torno dos ciclos e da progressão continuada ficou, segundo a SEE, inserido nas atividades de formação.

Durante a gestão Chalita desenvolvi atividades profissionais em um órgão intermediário da SEE, uma Diretoria de Ensino na cidade de São Paulo. Ocupava, na ocasião, a função de assistente técnico-pedagógico (ATP), atuando em um setor da DRE chamado Oficina Pedagógica. Tinha como função desenvolver os projetos de formação continuada propostos pela SEE, trabalhando com professores, professores coordenadores pedagógicos e, algumas vezes, com diretores das escolas. Com exceção do Fórum mencionado, que ocorreu em junho de 2002, do qual participaram apenas gestores dos órgãos intermediários do sistema de ensino (dirigentes, supervisores de ensino, ATP, técnicos da SEE), não houve outro evento, curso ou similar que colocasse em pauta a questão da organização do ensino em ciclos e a progressão continuada. Também, fora o referido Fórum, não ocorreram, nos encontros promovidos pela Coordenadoria de Normas Pedagógicas (CENP), órgão da SEE responsável pela orientação pedagógica à rede de ensino, debates, discussões ou estudos mais sistemáticos visando enfrentar os desafios e críticas ao ensino em ciclos e a progressão continuada.

Essa ausência de ações relacionadas à formação e investimentos na rede de ensino, visando à implementação da progressão continuada, ficou latente nas conclusões de todas as pesquisas que foram feitas sobre o tema.

Ocimar Munhoz Alavarse (2007) afirma que a "gestão de Gabriel Chalita, até 2005, manteve a postura de não discutir - efetivamente - a organização do ensino em ciclos - e as consequentes restrição e redução na reprovação - na rede estadual" (p. 129). Essa afirmação reitera o que as pesquisas aqui analisadas evidenciaram acerca da progressão continuada em São Paulo, ou seja, não há preocupação, por parte dos gestores, em debater com a rede os problemas advindos da eliminação da reprovação.

As pesquisas mais recentes, Zanini, Poliche e Jeffrey, todas de 2006, revelam que muitos professores não compreendem os pressupostos teóricos da progressão continuada e dos ciclos e continuam, a despeito da limitação da possibilidade de reprovação, desenvolvendo uma avaliação classificatória e excludente. 
As pesquisas aqui mencionadas, apesar de constatarem resistências quanto à idéia de reprovação, conseguiram identificar situações e práticas que, a despeito da falta de orientações, formação e investimentos dos órgãos gestores, vêm ressignificando as práticas avaliativas e demais práticas escolares, procurando compreender as idéias contidas na proposta, adequando essas idéias às suas condições reais de trabalho, evidenciando avanços importantes no repensar da escola.

Apesar de a maioria das pesquisas não ter como foco a avaliação da aprendizagem, a centralidade da avaliação na questão dos ciclos e da progressão escolar é tão marcante que, de algum modo, os estudos esbarram nesse tema. O que se evidencia é que no âmbito do discurso de profissionais das escolas pesquisadas nesses estudos e na fala da maioria dos professores está contida uma concepção de avaliação formativa, contínua, visando à garantia da aprendizagem dos alunos. Entretanto, a observação da prática não revela a presença de práticas avaliativas formativas, mas sim a permanência de uma perspectiva tradicional de avaliação, apesar da perda de significado em função da limitação da possibilidade de reprovar.

Encontramos exemplos dessa dificuldade em ressignificar a avaliação da aprendizagem em Delgado (2004, p.153) ao afirmar que "embora se tenha presenciado a prática da avaliação contínua e também algumas tentativas de mudanças, estas não foram suficientes para atingir de modo incisivo a sala de aula". Poliche (2006, p.49) constata que "a prática avaliativa do professor pouco se modificou no regime de progressão continuada, que sem um acompanhamento constante abre espaço para a aprovação automática”. A mesma autora relata ainda que:

Parece-nos claro que os professores entrevistados não têm clareza quanto ao papel da avaliação no regime de progressão continuada, já que ainda entendem a avaliação como um instrumento de mensuração de aprendizagem, aplicada com o único objetivo: determinar a aprovação ou retenção. (IDEM)

Apesar do estudo de Zanini (2006) não tratar especificamente da avaliação da aprendizagem, é esta pesquisa que identifica mudança nas práticas avaliativas no contexto da progressão continuada:

[...] pode-se observar fortemente, por meio dos depoimentos dos professores, as mudanças na forma de avaliar. A avaliação contínua, diagnóstica, diferenciada e com foco no progresso do aluno, é facilmente percebida quando os professores relatam a realidade atual da nova organização e, com isso, a necessidade de se preocupar, cada vez mais, com a participação, o progresso e, consequentemente, o aprendizado do aluno (p. 96). 
Em dissertação de mestrado, como já citado anteriormente, pesquisei as mudanças que estavam se processando nas práticas avaliativas em uma escola pública estadual de Ensino Fundamental. Nos documentos oficiais, emitidos pelo Conselho Estadual de Educação e pela Secretaria de Estado da Educação de São Paulo, e nos documentos produzidos pela escola pesquisada (projeto pedagógico, regimento escolar e planos de ensino) havia uma ênfase na necessidade de ressignificação da avaliação no regime de progressão continuada. Procurei identificar a visão dos alunos sobre a finalidade da avaliação após quatro anos de vigência da medida.

As conclusões a que pude chegar evidenciaram que havia, naquele momento, uma consonância no interior da escola pesquisada entre o discurso oficial sobre avaliação e o que estava registrado nos documentos oficiais da escola, a saber: na proposta pedagógica, no regimento escolar e nos planos de ensino. Entretanto, a opinião dos professores, coletada via questionário, sobre a progressão continuada e a avaliação, revelava, por um lado, a tentativa de compreender o papel da medida para a democratização do ensino, acesso e permanência dos alunos na escolaridade fundamental. Por outro lado, criticava a forma de implantação e a ausência de orientações e formação que permitissem aos professores melhor compreensão da progressão continuada e apoio no desenvolvimento de práticas avaliativas formativas:

Sempre que se fala em retirar a possibilidade de reprovação do aluno, a avaliação da aprendizagem perde a função de servir de referência para determinar quem é aprovado ou reprovado e, portanto, ou vai adquirir outra função ou não será mais necessária. A eliminação da possibilidade de reprovação se manifesta claramente na dificuldade em pensar a outra função para a avaliação, tornando-se, como afirma a professora, "oca". (ARCAS, 2003, p.73)

A fala dos alunos, coletada por meio de entrevistas coletivas, ainda estava marcada pelo medo da reprovação, pela necessidade de estudar e "tirar nota para passar de ano". A maioria dos alunos entendia que, quando não conseguia nota suficiente a responsabilidade recaía, quase que exclusivamente, sobre eles, restringindo-se o professor aos encaminhamentos burocráticos previstos, além de aconselhar os alunos a estudarem mais:

Essa idéia de que reprovar é preciso, que não adianta sair da escola sem saber, de que a reprovação é para o bem do aluno, remete a uma visão de ensino e de aprendizagem que está arraigada na cultura escolar. Mesmo após quatro anos de progressão continuada, e como os professores afirmando ser a avaliação contínua e formativa, no discurso dos alunos identifica-se que eles se consideram os únicos responsáveis pela não aprendizagem: foram eles que não se esforçaram, que não estudaram o necessário e, por isso, é melhor reprovar. Apesar dos argumentos que eles utilizaram para mostrar o lado 
ruim da reprovação, predomina uma tendência em achar que é melhor repetir do que passar sem saber. Para eles, apesar da reprovação ser um problema, ela surge como uma solução para a não aprendizagem, pois eles não se esforçaram, não estudaram, faltaram às aulas, devem fazer novamente 0 mesmo ano letivo para poder aprender. (ARCAS, 2003, p.101)

Outra questão muito enfatizada nas conclusões das pesquisas é o crescente desinteresse dos alunos pelo conhecimento escolar e a perda de poder dos professores por não poderem decidir ao final de todos os anos do Ensino Fundamental sobre a aprovação/reprovação dos alunos. Evidenciam os estudos que a dificuldade em usar a avaliação como instrumento de controle da disciplina e do interesse pelo estudo indica a necessidade de se estabelecerem novas relações entre professores e alunos:

De fato, os professores desenvolvem uma série de mecanismos de justificação e defesa do capital cultural e do habitus dos quais são possuidores e que engendram suas práticas e, mais do que isso, desenvolvem práticas "alternativas" capazes de minimizar os conflitos provocados pelas mudanças propostas pela implantação do regime de ciclos com progressão continuada. (SOUZA, 2004, p. 232)

Os estudos de Alavarse (2007) e Mainardes (2007), apesar de não tratarem especificamente da progressão continuada, se constituem em importantes pesquisas que buscaram discutir a política de ciclos no Brasil, analisando seus pressupostos teóricos, conceituais e políticos, além de contemplarem as experiências de implantação que se revelaram mais efetivas do ponto de vista da duração e abrangência. Entendemos, portanto, que podem contribuir para situar a questão da progressão continuada em São Paulo.

Alavarse, em pesquisa de doutorado, analisou o debate em torno da questão da seriação e da organização em ciclos. Seu estudo explorou essas duas possibilidades de organização do ensino no contexto atual, diante dos desafios da democratização do ensino e de melhoria da qualidade da educação pública. Ao discutir a questão da progressão continuada na rede estadual e procurar identificar qual projeto de escolarização e qual conceito de ciclo os textos oficiais continham, conclui que:

[...] são insuficientes as indicações e fundamentações contidas nos mesmos sobre os ciclos, quando existem. Não se encontra uma diretriz que avance significativamente uma concepção de ciclos e, muito menos, as determinações de medidas efetivas para sua implementação, embora, na rede estadual de São Paulo, como apresentado anteriormente, esteja em curso uma iniciativa envolvendo milhões de alunos e seus professores e constituindo um peso extremamente significativo no plano nacional, mas que não se sustenta nesses textos para difundir a organização do ensino em ciclos. Esse quadro é agravado, como enfatizei, pela orientação repetitiva de que cabe à escola formular sua proposta. (ALAVARSE, 2007, p.126) 
Alavarse ressalta que "não se eliminou o debate 'na base do sistema', mas a 'cúpula do sistema' não o encaminha adequadamente" confirmando as conclusões a que chegaram as pesquisas apresentadas anteriormente e revelando a resistência dos gestores do sistema em discutir o tema diante de tantos questionamentos; seja pelas pesquisas acadêmicas, seja pela comunidade escolar ou pelos dados apresentados na mídia.

A obra de Mainardes (2007) tem sua importância na análise aprofundada e detalhada que faz do desenvolvimento das políticas de ciclo no Brasil, do desenvolvimento dos ciclos de aprendizagem, da análise da documentação e das práticas na sala de aula. Diante da falta de entendimento e de clareza dos envolvidos nas iniciativas de ciclos e de progressão continuada, o estudo de Mainardes possibilita uma reflexão substancial para indicar caminhos para gestores, professores e para aqueles que não querem reproduzir um discurso difundido pela mídia ou divulgado por aqueles que, em períodos eleitorais, trazem o assunto para os palanques de campanha.

Podemos concluir que, nestes anos de vigência da progressão continuada, os estudos e pesquisas que trataram do tema refletem a ausência de uma política de enfrentamento das implicações geradas por essa medida. Os trabalhos feitos até o momento vêm alertando a necessidade de refletir sobre a progressão continuada e identificar o impacto que ela tem produzido na melhoria da qualidade de ensino. Vários estudos indicam a necessidade da Secretaria de Educação apoiar as escolas com orientações, formação e mudanças estruturais e organizativas que possibilitem a progressão escolar dos alunos sem rupturas, com garantia de ensino de qualidade e aprendizagem efetiva de todos os alunos.

Conclui-se, portanto, que a SEE durante uma década de progressão continuada não promoveu uma política educacional que viabilizasse a organização do ensino em ciclos. Além disso, ficou praticamente ao encargo de cada escola resolver os problemas advindos da implantação da progressão continuada. Essa situação promove, de alguma maneira, uma nova organização do trabalho escolar que, consequentemente, influencia na avaliação, seja redimensionando práticas já consolidadas na escola, seja promovendo outras concepções e práticas. 


\section{Capítulo II - O SISTEMA DE AVALIAÇÃO DO RENDIMENTO ESCOLAR DO ESTADO DE SÃO PAULO - SARESP}

Este capítulo visa apresentar o Sistema de Avaliação do Rendimento Escolar do Estado de São Paulo (SARESP) traçando, em linhas gerais, sua trajetória em mais de uma década de existência. Também apresentamos um panorama das pesquisas acadêmicas que tiveram como objeto o SARESP e, além disso, procuramos identificar, nos estudos analisados, relações evidenciadas entre as práticas avaliativas desenvolvidas no interior das escolas com a avaliação externa.

\subsection{Panorama histórico}

Não pretendemos aqui proceder a uma análise do SARESP enquanto política educacional, até porque pesquisas como as de Bauer (2005), Lopes (2007) e Machado (2003), com maior ou menor amplitude, fizeram, com bastante competência, essa análise. Ressalto, portanto, que se faz uso dessas pesquisas neste estudo para refletir sobre as relações que se estabelecem entre a avaliação externa, no caso o SARESP, e as práticas avaliativas no interior das escolas, o que interessa diretamente a essa pesquisa.

Sendo assim, para fazermos um panorama histórico do SARESP, utilizamos apenas a legislação que o implanta e normatiza, na medida em que ela reflete as principais mudanças efetuadas nesse sistema de avaliação desde seu início. Buscaremos no documento de implantação do SARESP e nas resoluções emanadas da SEE identificar as alterações pelas quais o SARESP passou. Portanto, traçaremos apenas um perfil dessa avaliação, sem tecer, neste momento, considerações e críticas a respeito das mudanças efetuadas.

Em 1996, a Secretaria de Estado da Educação de São Paulo implanta o chamado Sistema de Avaliação do Rendimento Escolar do Estado de São Paulo - SARESP, anunciando, conforme exposto no SARESP: Documento de Implantação (1996), que os objetivos dessa medida seriam: 
- Subsidiar a Secretaria de Educação na tomada de nas tomadas de decisão quanto à política educacional;

- Verificar o desempenho dos alunos da educação básica pra fornecer informações a todas as instâncias do sistema de ensino que subsidiem a capacitação dos recursos humanos do magistério; "a reorientação da proposta pedagógica das escolas, de modo a aprimorá-la; a viabilização da articulação dos resultados da avaliação com o planejamento escolar, capacitação e o estabelecimento de metas para o projeto de cada escola [...]" (grifo meu) (p. 7).

Para justificar a necessidade de implantar o sistema de avaliação, o Documento de Implantação apresenta a seguinte argumentação: a necessidade de "criar novas formas de gerir o sistema de ensino e as escolas"; a busca de "subsídios para aprimorar a gestão educacional e, sobretudo, o sistema de ensino como um todo"; que a "avaliação se constitua em subsídio constante para a gestão educacional, contribuindo, notadamente, para o aprimoramento do ensino em São Paulo" (p. 6-7).

O público alvo do sistema de avaliação se vinculava a cada uma das instâncias da estrutura da SEE, indo desde os gestores das políticas públicas, passando pelos órgãos centrais e intermediários, a escola, a comunidade escolar e a sociedade como um todo. Entretanto, interessa-nos diretamente ressaltar, devido ao foco deste estudo, que o público alvo nas escolas seria os diretores, os coordenadores e os professores, que seriam responsáveis pela "aplicação e correção das provas; análise dos resultados obtidos; tomadas de decisão com base nos que eles revelam, de modo a melhorar a qualidade do ensino" (p. 9).

Vale ressaltar que no Documento de Implantação, além de conter os pressupostos nos quais se fundamentava a política adotada, seus objetivos e procedimentos de desenvolvimento, identificava a forma de operacionalização das ações e previa a continuidade das atividades para os anos subsequentes de 1997 e 1998, já indicando certa continuidade dessa política.

Os trechos grifados até aqui no texto servem para evidenciar que na sua implantação o SARESP, enquanto estrutura, incluía de forma clara a participação das equipes escolares na avaliação, não só como forma de poder viabilizar a aplicação e correção das provas, mas de envolver professores, coordenadores e diretores na análise dos dados, na reflexão dos resultados obtidos e na elaboração de propostas a partir desses resultados analisados. Portanto, os procedimentos de desenvolvimento da avaliação previam a participação das escolas na aplicação dos testes, correção e análise dos resultados, além de um posicionamento da 
unidade escolar sobre seu resultado e propostas de superação dos problemas identificados na avaliação no âmbito da escola.

Com relação às aplicações previstas o Documento de Implantação trazia um quadro onde indicava que em 1996 seriam avaliados os alunos matriculados na $3^{\mathrm{a}}$ e $7^{\mathrm{a}}$ do Ensino Fundamental de todas as escolas do estado. Os alunos de ambas as séries seriam avaliados em Português e Matemática, e somente os alunos da $7^{\text {a }}$ série seriam avaliados em Ciências e Geografia/História. Os conteúdos de todas as provas remeteriam a serie anterior as avaliadas, ou seja, $2^{\mathrm{a}}$ e $6^{\mathrm{a}}$ série. Ainda no segundo semestre do mesmo ano haveria outra aplicação para estudantes de $3^{\mathrm{a}}, 5^{\mathrm{a}}$ e $7^{\mathrm{a}}$ séries, que fariam avaliação de Português, Matemática, História, Geografia e Ciências, a novidade ficaria por conta da introdução da redação.

Para 1997, o Documento previa que fossem avaliadas as $4^{\text {a }}$ e $8^{\text {a }}$ séries do Ensino Fundamental, nos mesmos componentes curriculares de 1996. Dessa vez a novidade foi o início da avaliação no $1^{\circ}$ ano do Ensino médio, sendo os alunos avaliados em Português, redação e Matemática. Em 1998 as séries do Ensino Fundamental avaliadas seriam $2^{\text {a }}$ e $6^{\text {a }}$, com provas de Português, redação e Matemática para as duas séries e Ciências, Geografia/História apenas para as $6^{\mathrm{a}}$. No Ensino Médio, alunos do $2^{\circ}$ ano seriam avaliados em Português, redação, Matemática, História, Geografia, Física, Biologia e Química.

É sabido que a SEE nos três anos contemplados no referido documento desenvolveu a avaliação externa da maneira como fora previsto, envolvendo as escolas, professores, diretores, supervisores, dirigentes, tentando esclarecer pais e alunos da importância da prova. Recebeu relatórios e emitiu relatórios sobre os resultados do SARESP e, segundo o discurso oficial, a partir dos resultados desencadeou ações no sistema.

No ano de 1999 não houve aplicação do SARESP, mas em 2000 a avaliação voltou a ocorrer. Nesse ano foram avaliadas as $5^{\mathrm{a}}$ e $6^{\mathrm{a}}$ séries do Ensino Fundamental e a $3^{\mathrm{a}}$ série do Ensino Médio, sendo que para as séries do Ensino Fundamental houve avaliações envolvendo os componentes curriculares de Língua Portuguesa, incluindo redação, Matemática e Ciências; enquanto que para o Ensino Médio as avaliações realizadas contemplaram Língua Portuguesa, incluindo a redação, Matemática e Biologia. Os alunos das séries avaliadas fizeram a prova de apenas um dos componentes curriculares.

Em 2000 o questionário destinado a gestão escolar passou a ser respondido pelo diretor e pelo professor coordenador, ocorrendo também à inclusão de um questionário que se 
destinava ao supervisor de ensino. A partir desse ano a avaliação passou a ser aplicada no final do ano, diferentemente do que vinha ocorrendo até então.

No ano de 2001 houve uma mudança na forma como a avaliação vinha ocorrendo. De acordo com a Resolução SE n 124, de 13 de novembro de 2001, o SARESP ocorreria nas séries finais dos ciclos I e II, portanto, o público alvo seria alunos concluintes das $4^{\mathrm{a}}$ e $8^{\mathrm{a}}$ séries. Ainda, de acordo com a Res. 124/2001, os alunos iriam realizar "atividades de Língua Portuguesa com vistas à avaliação das competências e habilidades básicas previstas para o término desses ciclos".

Sendo assim, o ano de 2001 marca duas mudanças importantes no SARESP: primeiro a avaliação assume, como objetivo, avaliar as competências que os alunos devem ter domínio ao final de cada ciclo e, em segundo lugar, a avaliação irá verificar o domínio dos alunos em relação às competências de leitura e escrita.

Mas, o que realmente causou maior impacto no SARESP 2001 foi a inclusão de um novo objetivo para a avaliação que seria "aferir, junto aos alunos, as condições para a continuidade de seus estudos no Ciclo II ou no Ensino Médio, uma vez que seus resultados se constituirão em indicador essencial para a promoção do aluno"(Art. $2^{\circ}$, Res. No 124/2001).

O uso dos resultados do SARESP para decidir sobre a continuidade de estudos dos alunos, ou seja, aprovação ou reprovação ao final do ano letivo revelou, naquele momento, um uso que a avaliação externa ainda não havia adquirido desde sua adoção em 1996.

Quando os resultados do SARESP aplicado ao final daquele ano foram divulgados, os alunos que não atingiram média na prova objetiva foram encaminhados para a recuperação realizada no mês de janeiro do ano seguinte. No início de 2002, após o período de recuperação, os alunos foram submetidos a uma nova avaliação e, a partir desse resultado, encaminhados para a série seguinte ou para turmas de recuperação de ciclo. Essas determinações estavam expressas na Resolução SE nº 14, de 18 de janeiro de 2002.

Vale lembrar que em abril de 2002 ocorreu a troca dos gestores frente à SEE, marcando o término da gestão de Rose Neubauer, iniciada em 1995, e o começo da gestão de Gabriel Chalita, que iria até o primeiro quartel de 2006. No final do ano o SARESP ocorreria nos moldes do ano anterior, 2001, mas o resultado não foi utilizado para definir a continuidade dos estudos dos alunos avaliados. 
A nova gestão iria imprimir mudanças no SARESP somente em 2003, quando a avaliação passou a ser censitária para todas as escolas e alunos da Educação Básica, ou seja, todos os alunos do Ensino Fundamental e Ensino Médio foram submetidos à aplicação do SARESP. Ficaram de fora da avaliação apenas os alunos da Educação de Jovens e Adultos (EJA).

A Resolução SE 120/2003 definia, em seu artigo $2^{\circ}$ que os alunos seriam submetidos a "uma prova de Leitura e Escrita com vistas à avaliação das habilidades básicas previstas ao final de cada série." Ainda, segundo a Resolução, no artigo $4^{\circ}$, indicava que a prova seria constituída de questões predominantemente abertas para a $1^{\mathrm{a}}$ e $2^{\mathrm{a}}$ séries do Ensino Fundamental e para as demais séries questões de múltipla escolha e uma proposta de tema para redação. No ano seguinte o SARESP manteria a mesma estrutura e características de 2003, conforme o exposto na Resolução SE nº 101/2004.

No SARESP de 2005, apesar de manter as mesmas características de 2003 e 2004, ou seja, censitário para todos os alunos e séries do Ensino Fundamental e Ensino Médio, a grande novidade seria a introdução de uma prova de Matemática, lembrando que a última vez que esse componente curricular havia sido avaliado foi no SARESP de 2000. Para a realização das provas de Leitura e Escrita e de Matemática, além da redação a partir da $3^{\text {a }}$ série do Ensino Fundamental, o SARESP ocorreu em dois dias, sendo distribuídos entre eles as provas de Leitura e Escrita, Matemática, redação e o questionário sócio-econômico para os alunos.

Em 2006 ocorreu mudança na gestão do governo estadual com o afastamento do governador Geraldo Alckmin para candidatar-se a presidência da República. Assume, então, o governo do Estado o vice-governador Cláudio Lembo e Maria Lúcia Marcondes Carvalho Vasconcelos substitui Gabriel Chalita à frente da Secretaria da Educação.

A nova secretária anunciou a suspensão do SARESP em 2006, alegando a necessidade de analisar os resultados e rever o modo como a avaliação vinha sendo desenvolvida. Como parte desse processo de avaliação e revisão do SARESP a SEE organizou um seminário em outubro de 2006 com o objetivo de:

a. Aprofundar conhecimentos sobre a avaliação educacional e escolar;

b. Refletir sobre as características e objetivos de diferentes sistemas de avaliação externa (SARESP e ENEM);

c. Refletir sobre as relações entre avaliação externa e avaliação interna; 
d. Discutir, identificar e propor ações que articulem metodologias de ensino e projetos educacionais, tendo em vista o enfrentamento dos dados de desempenho das últimas avaliações. (Caderno de Memórias/CENP/SEE, 2007, p.4).

O público alvo desse seminário foram supervisores de ensino, diretores e professores coordenadores de escolas de Ensino Médio, professores de Língua Portuguesa e de Matemática e Assistentes Técnicos Pedagógicos (ATP) de Língua Portuguesa e Matemática de todas as Diretorias Regionais de Ensino. O encontro reuniu 900 profissionais da educação entre representantes das Diretorias de Ensino e escolas. A SEE ainda não havia promovido um encontro dessa magnitude com os profissionais da rede para discutir o SARESP e a avaliação de um modo geral.

Após as eleições para o governo estadual no final de 2006 é eleito José Serra como governador do Estado para o período de 2007-2010. O governador manteve Maria Lúcia Marcondes Carvalho Vasconcelos como Secretária de Educação até julho de 2007, quando assumiu a SEE Maria Helena Guimarães Castro.

Em 20 de agosto de 2007, a Secretária de Educação e o governador José Serra anunciam o Plano de Metas para 2010, sendo que, a $5^{\text {a }}$ meta do plano estipula um aumento de 10\% nos índices de desempenho do Ensino Fundamental e Médio nas avaliações nacionais e estaduais. Ao estabelecer essa meta a secretária indica a continuidade do SARESP e nas "10 Metas para uma Escola Melhor", em relação às metas 08, Sistemas de Avaliação, e 09, Gestão de Resultados e Política de Incentivos, define as seguintes ações:

\section{8- Sistemas de Avaliação:}

Realização, no próximo mês de outubro, do SARESP 2007 com avaliação das seguintes séries: Ensino Fundamental (1 ${ }^{\mathrm{a}}, 2^{\mathrm{a}}, 4^{\mathrm{a}}, 6^{\mathrm{a}}$ e $8^{\mathrm{a}}$ séries) e Ensino Médio: $3^{\mathrm{a}}$ série.

A avaliação externa das escolas estaduais (obrigatória) e municipais (por adesão) permitirá a comparação dos resultados do SARESP com as avaliações nacionais (SAEB e a Prova Brasil), e servirá como critério de acompanhamento das metas a serem atingidas pelas escolas.

Participação de toda a rede na Prova Brasil (novembro de 2007).

Realização de programas de capacitação da rede para a participação no SARESP e na Prova Brasil, em setembro de 2007.

Capacitação dos professores para o uso dos resultados do SARESP no planejamento pedagógico das escolas em fevereiro de 2008.

Divulgação dos resultados do SARESP 2007 para todas as escolas, professores, pais e alunos em março de 2008. 


\section{9- Gestão de Resultados e Política de Incentivos:}

Implantação de incentivos à boa gestão escolar valorizando as equipes.

O SARESP 2005 e as taxas de aprovação em 2006 serão a base das metas estabelecidas por escola.

Também serão considerados indicadores como a assiduidade dos professores e a estabilidade das equipes nas escolas.

Cada escola terá metas definidas a partir da sua realidade, e terá que melhorar em relação a ela mesma.

As escolas com desempenho insuficiente terão apoio pedagógico intensivo e receberão incentivos especiais para melhorarem seu resultado.

As equipes escolares que cumprirem as metas ganharão incentivos na remuneração dos profissionais ${ }^{14}$.

As metas e ações propostas pela SEE permitem compreender que na atual gestão a avaliação externa, seja o SARESP ou avaliações propostas pelo Governo Federal, tem papel importante na gestão do sistema de ensino e das escolas. Em outubro, a Resolução SE no 68/2007 define os procedimentos para a realização do SARESP.

As mudanças processadas para o SARESP 2007 se referiam essencialmente as séries avaliadas, como já anunciado na $8^{\mathrm{a}}$ meta para uma escola melhor, sendo avaliadas as seguintes séries: Ensino Fundamental 1 $1^{\mathrm{a}}, 2^{\mathrm{a}}, 4^{\mathrm{a}}, 6^{\mathrm{a}}$ e $8^{\mathrm{a}}$ séries e Ensino Médio apenas a $3^{\mathrm{a}}$ série. Segundo a Resolução n 68/2007, em seu artigo 2ª a avaliação "visa aferir o domínio das competências e habilidades básicas previstas para o término de cada série a ser avaliada e consistirá de provas de Língua Portuguesa e de Matemática”.

Apesar do recorte temporal deste estudo ir até o ano de 2007, consideramos importante situar algumas mudanças que se processaram em relação ao SARESP na edição de 2008. Em 2008, as séries avaliadas continuaram sendo as mesmas que em 2007, entretanto, houve uma ampliação das disciplinas a serem avaliadas, pois além de Português e Matemática, foram aplicadas provas de Ciências, para o Ensino Fundamental, e Biologia, Física e Química para o Ensino Médio. Para a edição de 2009, a SEE prevê a aplicação de provas de Geografia e História, tanto no Ensino Fundamental como no Ensino Médio.

\footnotetext{
${ }^{14}$ Disponível em: www.educacao.sp.gov.br. Acesso em: 27 de setembro de 2007.
} 
Outra modificação importante foi a adoção pela Secretaria de Educação da Teoria da Resposta ao Item (TRI) como metodologia para a realização da avaliação externa. Essa modificação impõe ao SARESP um rigor metodológico e a possibilidade de comparação entre as diferentes edições, permitindo um acompanhamento mais sistemático dos resultados da avaliação. As mudanças promovidas no SARESP durante sua existência e a ausência de uma metodologia única sempre gerou intenso debate sobre a confiabilidade de seus resultados.

O SARESP, desde sua implantação em 1996, foi considerado pelos gestores do sistema de ensino como uma política de grande importância. Sua permanência, enquanto política e os objetivos anunciados pela Secretaria de Educação para a avaliação externa confirmam essa importância na gestão do sistema e da escola:

Na concepção adotada no SARESP, a avaliação visa promover uma reflexão sobre a qualidade do ensino e encontrar alternativas para melhorá-la, de modo que se possa transformar a prática pedagógica no sentido esperado e redirecionar as políticas públicas na área educacional, sempre que necessário. (BITAR et al, 1998, p. 12).

Mais recentemente, em março de 2008, a Secretária de Educação, Maria Helena Guimarães Castro, em notícia publicada no site da Secretaria de Educação, anunciava a criação do Índice de Desenvolvimento da Educação no Estado de São Paulo (IDESP) ${ }^{15}$, demonstrando a importância do SARESP para o cálculo do índice e para o pagamento do bônus aos profissionais da escola baseado:

O SARESP (Sistema de Avaliação de Rendimento Escolar do Estado de São Paulo) retornou em 2007 para avaliar o rendimento escolar dos alunos, podendo, assim, acertar caminhos e projetar alterações, se necessárias. E esta avaliação também será fundamental para definição do projeto de remuneração por desempenho, a ser implantado já neste ano. O novo SARESP será o principal ponto do índice que a Secretaria criará. Ainda entrarão critérios como assiduidade da equipe e aprovação/reprovação dos alunos. ${ }^{16}$

Dessa maneira, estudos e pesquisas que possam identificar os impactos do SARESP na rede de ensino são importantes para evidenciar se seus objetivos estão sendo alcançados, principalmente no tocante a melhoria da qualidade do ensino. Em estudo realizado por Sousa

\footnotetext{
${ }^{15}$ Segundo informações no site da SEE o IDESP é um indicador de qualidade das séries iniciais ( $1^{\text {a }}$ a $4^{a}$ séries) e finais ( $5^{\mathrm{a}}$ a $8^{\mathrm{a}}$ séries) do Ensino Fundamental e do Ensino Médio. Na avaliação de qualidade das escolas feita pelo IDESP consideram-se dois critérios complementares: o desempenho dos alunos nos exames do SARESP e o fluxo escolar. O IDESP tem o papel de dialogar com a escola, fornecendo um diagnóstico de sua qualidade, apontando os pontos em que precisa melhorar e sinalizando sua evolução ano a ano. Disponível em: http://idesp.edunet.sp.gov.br/o_que_e.asp. Acesso em: 03 de novembro de 2008.
}

${ }^{16}$ Disponível em: www.educacao.sp.gov.br. Acesso em: 13 de março de 2008 
e Oliveira (2007) sobre sistemas de avaliação estaduais, os pesquisadores indicaram em suas considerações as tendências que vêm se delineando em relação à avaliação externa e a importância que eles estão adquirindo para a escola, para o sistema de ensino e a sociedade como um todo:

Os objetivos da avaliação, declarados nos documentos oficiais, tendem a afirmar como expectativa que a avaliação venha a subsidiar os diferentes níveis do sistema na tomada de decisões com vistas à melhoria da qualidade do ensino. Desse modo, espera-se que os resultados da avaliação venham a ser apropriados pelos gestores e equipes centrais e regionais das Secretarias de Educação bem como pelas escolas, havendo menção ainda, por alguns Estados, quanto à expectativa de que a comunidade escolar como um todo envolvendo alunos e pais - venha a se inteirar dos resultados obtidos pelas escolas. Ou seja, há referências a que a avaliação deva iluminar e trazer conseqüências para a formulação e/ou reformulação das políticas educacionais, em relação às suas diretrizes, prioridades e metas, focalizando questões relativas à gestão, currículo e infra-estrutura, assim como nas propostas e práticas das escolas, particularmente em relação a aspectos relativos ao desenvolvimento do currículo (p.187).

Ao percorrermos a trajetória do SARESP, as mudanças que se processaram durante suas 10 edições, conclui-se que ele se configura como uma política permanente e, ao observarmos as metas da SEE até 2010, percebe-se a centralidade da avaliação na gestão do sistema de ensino e das escolas estaduais.

Atualmente, ampliam-se as iniciativas do Ministério da Educação e dos sistemas de ensino estaduais em estimular o uso dos resultados obtidos nas avaliações externas, sistematizando metas e/ou estabelecendo a meritocracia e a bonificação como forma de valorizar os profissionais da educação e melhoria da qualidade de ensino, segundo os gestores que estão implementando estas estratégias enquanto políticas educacionais. Um exemplo dessa política de incentivos tem-se verificado na Secretaria de Educação de São Paulo.

\subsection{Panorama das Pesquisas Acadêmicas}

Pretende-se, neste item, traçar um panorama das pesquisas que foram desenvolvidas tendo como objeto o SARESP. As pesquisas contribuem para a compreendermos como esta política vem se desenvolvendo e como tem impactado a rede pública estadual. As conclusões a que chegaram essas pesquisas contribuem para as análises que serão desenvolvidas neste estudo. 
Para traçarmos este panorama utilizamos nove estudos sobre o SARESP, sendo 08 dissertações de mestrado e apenas 01 tese de doutorado. Não se pretendeu fazer uso de todas as pesquisas feitas sobre o SARESP, mas apenas aquelas que proporcionaram uma visão de como esta medida vêm impactando as escolas. A seguir apresentaremos os trabalhos de Oliveira (1998); Esteves (1998); Felipe (1999), Kawauchi (2001); Ribeiro (2001); Bosquetti (2002); Machado (2003); Barbosa (2005) e Bauer (2006) ${ }^{17}$.

O estudo de Duzolina A. Felipe de Oliveira (1998) teve como objetivo fazer uma análise dos princípios que nortearam a implantação do Sistema de Avaliação do Rendimento Escolar de São Paulo (SARESP), sua viabilidade funcional e seu potencial de efetividade. Para tanto, o estudo realizou-se considerando os anos de 1995, 1996 e 1997, sendo feita análise dos documentos de implantação e divulgação do SARESP. Utilizaram-se também os resultados das avaliações feitas em 1996 e 1997 e a pesquisadora se propôs a fazer uma avaliação política do SARESP.

Oliveira reconhece a importância do SARESP enquanto política educacional, devido, segundo ela, a busca de criação de uma cultura de avaliação que pode contribuir para a melhoria a qualidade do ensino, e considera o SARESP como um instrumento cujo objetivo é "o estabelecimento na rede estadual, de uma cultura avaliativa embasada na avaliação formativa" (1998, p.73). Entretanto, critica a forma como a SEE implanta sua política, sem diálogo com a rede, pois "a equipe escolar torna-se mera executora das determinações desses órgãos. Assim, não se exercita a autonomia. Engole-se o que se impôs” (idem, p.74). Concluindo seu estudo, Oliveira afirma que apesar do SARESP se constituir em uma política que pode auxiliar na melhoria da qualidade do ensino, apresenta-se como um projeto falacioso, "no qual o formal não é sério e que não apresenta caminhos de participação" (ibidem).

A pesquisa de Maria E. de P. Pinto e Esteves (1998) visou investigar o impacto causado pelo SARESP nas escolas e identificar mudanças nas práticas pedagógicas provocadas por seus resultados. Seu estudo teve como foco os professores de Língua Portuguesa das séries finais do Ensino Fundamental. Para realizar seu estudo selecionou cinco escolas de uma

\footnotetext{
${ }^{17}$ De acordo com as normas da ABNT a sequência de autores deveria ser organizada em ordem alfabética. Entretanto, o objetivo da seqüência é apresentar os trabalhos em ordem cronológica, que será utilizada na sua organização.
} 
Diretoria Regional de Ensino da capital paulista nas quais procedeu a observações do cotidiano escolar, realizou entrevistas e aplicou questionários.

Segundo Esteves, os professores receberam o SARESP com reservas, por desconhecerem esta prática avaliativa ou por não terem compreendido seus objetivos. A resistência foi maior na primeira aplicação, em 1996, já em 1997, na segunda aplicação, a resistência diminuiu, mas não deixou de existir. Conforme concluiu Esteves, apesar das resistências, os resultados do SARESP serviram para promover nas equipes escolares a necessidade de refletir e ampliar seus conhecimentos acerca da avaliação.

Ao contrário de Oliveira, Esteves, nas suas conclusões, vê o SARESP com maior otimismo, considerando a necessidade de se pensá-lo, a longo prazo, compreendendo a avaliação externa como algo promissor e viável, mas que dependerá das orientações e ações emanadas dos órgãos centrais, na utilização dos resultados e na condução de políticas que visem à melhoria da qualidade do ensino.

Jesse Pereira Felipe (1999) também se propôs a investigar o impacto dos resultados do SARESP e identificar possíveis mudanças na escola. A pesquisa foi realizada em quatro escolas de uma mesma Diretoria Regional de Ensino, nas quais o pesquisador acompanhou a aplicação do SARESP e as ações posteriores a aplicação. A edição do SARESP analisada foi a de 1998 e a pesquisa se desenvolveu a partir da leitura de documentos oficiais, entrevistas e questionários com os responsáveis pela aplicação do SARESP na diretoria de ensino e na escola.

Felipe, em suas conclusões, indica que, a princípio, havia uma expectativa que o SARESP viesse proporcionar uma melhoria da qualidade do ensino. Porém, a pesquisa revelou que o SARESP gerou uma série de problemas, como a desconfiança dos professores sobre seus reais objetivos, inadequação dos instrumentos para o nível dos alunos e falta de ações desencadeadas a partir dos resultados da avaliação.

Entretanto, Felipe ressaltou a importância da avaliação das escolas para o enfrentamento do fracasso escolar, concluindo que:

"a avaliação deve ter como premissa que ela não será, sob hipótese alguma, usada contra os professores, muito menos poderá ser usada para a elaboração de ranking, estigmatizando e dividindo as escolas em 'más' e 'boas', as escolas de 'sucesso' e as 'fracassadas'” (1999, p.53). 
O estudo de Mary Kawauchi (2001) teve como objetivo discutir implicações da avaliação externa no ensino de História, identificando o ponto de vista dos professores desta disciplina em relação à avaliação e seus reflexos na prática pedagógica. Sendo assim, foram realizadas entrevistas com 14 professores de História da rede estadual de ensino.

Kawauchi apontou em suas conclusões alguns indícios do impacto do SARESP na escola e no ensino de História. Segundo ela, uma questão que se evidenciou com a pesquisa foi a falta de esclarecimento dos objetivos do SARESP para os professores, de um modo geral. Ressaltou também que a avaliação pode assumir um caráter coercitivo a partir da divulgação do desempenho das escolas. Outro aspecto considerado por Kawauchi foi à complexidade do ensino de História, das discussões téorico-metodológicas que ocorrem em torno do currículo dessa disciplina e da ausência de um currículo rígido, o que dificulta a criação de parâmetros para a avaliação da disciplina. Enfatiza a autora que a flexibilidade do currículo de História dificulta a elaboração da avaliação, e se for mantida nessa disciplina produzirá interferências no trabalho do professor.

A pesquisa de Alessandro J. Ribeiro (2001) teve como foco as questões de Matemática utilizadas na prova do SARESP em 1997. O autor procurou levantar, identificar e analisar os procedimentos e estratégias que os alunos das $8^{\text {a }}$ séries Ensino Fundamental utilizam para resolver questões de Álgebra Elementar. Essa pesquisa, na verdade, apenas toma o SARESP como pano de fundo para sua realização, pois não tem como objetivo central a avaliação, mas as estratégias para resolver as questões propostas. Porém, evidencia a mobilização de pesquisadores e professores da Educação Básica a partir da avaliação externa, gerando uma reflexão em torno da aprendizagem.

Maria Carolina Bonna Bosquetti (2002) procura, por meio de seu estudo, identificar na prova questões de visualização em Geometria, observando as habilidades e competências relativas à interpretação de informação figurativa. Para identificar nos alunos a habilidade de interpretação e informação figurativa, a pesquisadora desenvolveu estudo em uma escola com duas turmas de $3^{\circ}$ ano de Ensino Médio. Como conclusão a pesquisadora indica que poucos alunos possuem a habilidade de visualização desenvolvida e que as provas do SARESP não permitem a observação da competência e da habilidade propostas pela prova.

Cristiane Machado (2003), em tese de doutorado, analisa a utilização dos resultados do SARESP, edição do ano 2000, como instrumento que visa para direcionar ações para a melhoria da qualidade do ensino no âmbito das Diretorias Regionais. Para desenvolver o 
estudo, a autora utilizou-se da leitura e análise de 88 relatórios produzidos sobre os resultados do SARESP de 2000, pelas escolas e diretorias de ensino. Procurou identificar nos relatórios as propostas de ações políticas subsidiadas a partir dos resultados do SARESP e seu potencial para a melhoria da qualidade do ensino.

O estudo de Machado caracterizou-se como uma análise da política educacional relacionada a avaliação e concluiu que o SARESP, apesar do seu potencial para desencadear e direcionar ações e políticas visando à melhoria da qualidade do ensino, tem se prestado ao estabelecimento de ranking que gera a comparação entre as escolas. Entretanto, não deixa de evidenciar a importância da avaliação externa e do seu potencial em identificar problemas educacionais e gerar ações que possam promover um ensino de melhor qualidade.

Geraldo Carlos Barbosa (2005) faz, em sua pesquisa, um recorte mais específico em torno do desenvolvimento das habilidades de leitura e da escrita. A partir da prova do SARESP aplicada em 2003 para alunos de $3^{\text {a }}$ série do Ensino Médio, dos questionários sócioeconômicos das aplicações de 2003 e 2005, do relatório dos aplicadores e do manual de instruções, o autor desenvolveu pesquisa documental voltada à utilização dos gêneros, habilidades e conteúdos mobilizados.

A pesquisa concluiu que apesar do SARESP adotar uma perspectiva reducionista da linguagem na relação dos sujeitos nela envolvidos, pode-se considerá-lo como ponto de partida para uma revisão dos processos de ensino-aprendizagem da Língua Portuguesa.

Adriana Bauer (2006) procurou identificar a utilização dos resultados do SARESP na formulação de ações de formação de professores. Para tanto, a pesquisa desenvolvida abrangeu as diretorias de ensino situadas na cidade de São Paulo.

O estudo, de caráter qualitativo, fez uso de enquete com caráter exploratório. A autora fez análise de documentos oficiais sobre a política educacional, além da teoria que fundamenta o debate em torno da avaliação e da formação de professores. Concluiu-se com a pesquisa que a articulação entre os resultados do SARESP e a política de formação docente, como previsto nos documentos de implantação e implementação do SARESP, ainda não está consolidada:

[...] a idéia de que a avaliação externa serve para subsidiar a formação docente permeia o discurso de muitos dos profissionais entrevistados. Entretanto, nesses depoimentos não são oferecidos indícios que evidenciam essa relação, ou seja, há uma grande aceitação do discurso oficial, inferida a 
partir de expressões como "eles sabem", "a partir dos resultados", "está subsidiando" etc. (BAUER, 2006, p.135).

De um modo geral, a política de formação tem suas ações definidas de forma centralizada, apesar de existirem algumas iniciativas no âmbito das diretorias regionais de ensino.

As pesquisas apresentadas revelam que o SARESP se configura como uma política que possui uma abrangência muito grande. Nas primeiras edições percebe-se que as pesquisas apresentam como impacto inicial certa resistência dos professores em função da ausência de uma prática de avaliação de sistema no Estado de São Paulo. Nos três primeiros anos de vigência do SARESP os estudos remetem à necessidade de orientação dos professores e não ranqueamento dos resultados.

Alguns estudos, que centram sua análise em componentes curriculares específicos, caso das pesquisas de Barbosa (2005), Bosquetti (2002), Kawauchi (2001) e Ribeiro (2001) possibilitam uma reflexão e análise de como o SARESP tem um potencial de influenciar a construção do currículo, de induzir estratégias de ensino e de introduzir nas escolas a preocupação com o desenvolvimento das habilidades e competências que fazem parte da prova.

Já as pesquisas de Bauer (2006) e Machado (2003) são fundamentais para a compreensão e análise do papel do SARESP na definição das políticas de gestão da educação no estado de São Paulo.

A história que vem sendo construída da avaliação do sistema de ensino paulista e a abrangência dessa política de avaliação exigem estudos que possam identificar seu impacto nas práticas pedagógicas desenvolvidas nas escolas da rede pública ${ }^{18}$.

Creso Franco (2004), ao iniciar artigo em que visa refletir sobre as contribuições da avaliação para as políticas educacionais, se posiciona favoravelmente a realização das avaliações em larga escala, afirmando que tem "razões para vislumbrar que essas

\footnotetext{
${ }^{18}$ Importante contribuição para as pesquisas sobre a temática é o estudo desenvolvido por Sousa e Oliveira (2007) sobre os sistemas de avaliação educacional no Brasil, identificando suas características, tendências e usos dos resultados. O estudo considerou os sistemas de avaliação dos estados da Bahia, Ceará, Minas Gerais, Paraná e São Paulo, sistematizando informações, dados e traçando um panorama dos sistemas estudados e as tendências e perspectivas que se apresentam para a avaliação externa.
} 
avaliações podem dar contribuições relevantes às políticas educacionais," e isto não significa desprezar "as críticas que colegas podem fazer às avaliações em larga escala. Devo dizer que considero os debates sobre os prós e contras de nosso 'tempo de avaliação' como sendo algo relevante" (p. 45).

A expressão "tempo de avaliação" revela a importância que a avaliação adquiriu desde os anos 1990 e o posicionamento do pesquisador apresenta-se como tendência nas análises que são feitas sobre as avaliações em larga escala. Se atualmente há certo consenso acerca da necessidade da avaliação e suas contribuições para a gestão dos sistemas e das escolas, por outro, os processos de aferição do desempenho dos alunos e usos dos resultados ainda são aspectos problematizados pelos estudiosos desta temática.

Quando os objetivos explicitados da avaliação externa se relacionam a promoção da melhoria da qualidade de ensino, isso significa identificar os pontos frágeis do sistema de ensino; verificar o que ocorreu com o investimento em formação de professores e em alocação de materiais e analisar as condições sociais para o desenvolvimento de políticas que apóiem a educação; os pesquisadores se posicionam favoravelmente a realização da avaliação.

Entretanto, quando a avaliação se presta, com maior ênfase, à responsabilização de professores e escolas pelo desempenho dos alunos, gerando premiação, punição e competição pela publicização dos resultados e ranqueamento das escolas, inúmeras críticas são manifestadas pelos pesquisadores.

Afonso (2005) ao tratar da questão da avaliação e modelos de responsabilização em educação, evidencia que:

A avaliação de sistemas educativos aparece doravante associada à responsabilização pelos resultados escolares dos alunos, sendo estes obtidos, sobretudo, pela utilização de teses estandardizados. Esta prática acaba assim, por contribuir para a divulgação de uma associação entre conceitos que são diferenciados: se a prestação de contas pelos resultados obtidos pressupõe a avaliação, esta última não implica necessariamente a prestação de contas (p. $44)$.

Portanto, não há uma vinculação necessária entre avaliação e prestação de contas. A questão que se apresenta não é a oposição em relação à avaliação externa, mas sim ao uso que se faz dos resultados. O que podemos indicar é que a utilização dos resultados pelos sistemas de ensino ainda não se delineou em uma direção mais definida. Ao mesmo tempo em que se anuncia como elemento de gestão das políticas públicas para a melhoria 
da qualidade do ensino, também está presente, cada vez mais, seu uso como prestação de contas, premiação e punição.

O certo é que os dados gerados pelas avaliações externas no Brasil e nas unidades federadas são pouco utilizados pelos gestores do sistema para delineamento de políticas e pelas escolas no planejamento escolar. Em 2001, Barretto já alertava que "os sistemas nacionais de avaliação vêm demonstrando insuficiente aproveitamento de informações produzidas, do que decorre o pequeno impacto nas redes escolares" (p.61).

A situação, até o presente momento, parece não ter se modificado, como evidencia Sousa (2008):

Embora a avaliação de sistemas educacionais venha se apresentando como importante instrumento de gestão da educação no âmbito nacional das unidades federadas, capaz de contribuir para a promoção da qualidade do ensino, poucas informações se tem sobre como seus resultados vêm sendo utilizados para a formulação e implementação de políticas educacionais (p. 08)

Dessa forma, existem muitos aspectos relacionados à avaliação externa não consolidados. Escolas e sistemas de ensino ainda não se apropriaram de modo sistematizado dos resultados da avaliação, além de não explorá-los em todas as potencialidades possíveis.

No entanto, as informações produzidas com a presente pesquisa permitem supor que o SARESP tende, gradativamente, a incidir com maior intensidade nos encaminhamentos de políticas educacionais e de propostas de ensino. Dentre as iniciativas que apóiam esta interpretação, tem-se a reestruturação do SARESP na edição de 2007, incluindo-se a aplicação de provas de outras disciplinas, a criação do IDESP e a introdução de uma nova proposta curricular para o Estado de São Paulo, que será tomada como referência para a elaboração das provas do SARESP. Além disso, há que se considerar que ações de formação de professores e organização centralizada de materiais didático-pedagógicos para as escolas, são balizadas por indicadores fornecidos pelos resultados da avaliação externa.

Quanto às escolas, possivelmente, venham a se intensificar o uso dos resultados do SARESP no delineamento das formas e conteúdos das avaliações, como poderemos notar nos dados coletados na pesquisa e apresentados no capítulo seguinte. 


\section{CAPÍTULO III - PROGRESSÃO CONTINUADA, SARESP E AVALIAÇÃO ESCOLAR: O QUE DIZEM OS PROFESSORES COORDENADORES?}

Neste capítulo são apresentados os elementos que caracterizam a pesquisa de campo e os dados que foram coletados. A coleta de dados ocorreu em dois momentos, primeiro por meio de um questionário aplicado aos professores coordenadores que atuam nas escolas de Ensino Fundamental e depois por meio de entrevistas com 11 professores coordenadores.

Os procedimentos utilizados na coleta de dados foram apresentados na introdução deste estudo. Retomaremos aqui alguns elementos que são importantes para situarmos o contexto em que se desenvolveu essa pesquisa.

Ao pensar em como obter respostas para as questões propostas nesta pesquisa, vimos nos professores coordenadores os profissionais que, por sua função na escola, seriam os mais indicados para dar pistas de como a progressão continuada e o SARESP vêm incidindo sobre a avaliação. Os professores coordenadores são os profissionais que têm por função acompanhar e orientar o trabalho pedagógico e proporcionar aos professores formação para atuarem frente às inovações pedagógicas e as mudanças propostas pela política educacional.

Nesse sentido, cabe a eles estabelecer o vínculo entre a sala de aula, por meio de sua atuação junto aos professores e alunos, e os órgãos gestores do sistema. Apesar do diretor da escola ser o responsável pela implementação da política educacional, ainda recai sobre ele muito mais questões administrativas que pedagógicas. As questões de caráter pedagógico ficam ao encargo do professor coordenador, tornando, esse profissional, importante figura na organização do trabalho escolar.

$\mathrm{Na}$ rede estadual o professor coordenador não é considerado cargo, não integrando a estrutura da carreira. Vale lembrar que na rede estadual são cargos apenas os de professor, diretor de escola e supervisor de ensino. As demais atividades realizadas por profissionais da educação são consideradas como funções e são exercidas por pessoas que ocupam um dos três cargos da carreira.

É na condição de função que atuam os professores coordenadores. Portanto, quem ocupa a função de professor coordenador é um docente. Para ter o direito de exercer a função 
de professor coordenador a Secretaria de Estado da Educação de São Paulo estabeleceu um processo seletivo, por meio do qual os professores ganham o direito de pleitear uma coordenação.

Historicamente, a necessidade de um profissional que estivesse fora da sala de aula, acompanhando e orientando o trabalho pedagógico, foi vista como forma de possibilitar a melhoria da qualidade do ensino. Esse profissional faria a articulação do trabalho pedagógico e apoiaria os professores nas ações desenvolvidas no cotidiano escolar. Além disso, seria responsável pela busca de informações, teorias, propostas que, apresentadas aos professores, poderiam auxiliá-los no encaminhamento das dificuldades de aprendizagem dos alunos. Orsolon (2001) ressalta a importância do trabalho do professor coordenador articulando o coletivo da escola:

O coordenador é apenas um dos atores que compõem o coletivo da escola. Para coordenar, direcionando suas ações para a transformação, precisa estar consciente de que seu trabalho não se dá isoladamente, mas nesse coletivo, mediante a articulação dos diferentes atores escolares, no sentido da construção de um projeto político-pedagógico transformador (p.19).

Na rede estadual a figura do professor coordenador surgiu na década de 1980 para atuar junto ao ciclo básico de alfabetização e depois, na década de 1990, para atuar na Escola Padrão $^{19}$. Na primeira gestão de Rose Neubauer (1995-1998) houve a extinção da Escola Padrão e a figura do professor coordenador, a partir de 1996, passou a compor o quadro de todas as escolas da rede. Naquela ocasião a escola poderia contar com um professor coordenador por período, atuando o do diurno por 40 horas/semanais e o do noturno por 24

\footnotetext{
${ }^{19}$ Segundo Garita, a Escola-Padrão foi um dos fatores marcantes do Governo Fleury (1991-1995). Tinha como objetivos a recuperação da qualidade do ensino público, a ampliação da participação da sociedade e a melhoria da utilização dos recursos. A Escola-Padrão pareceu ser um avanço na política educacional, pois ofereceu a estas escolas uma autonomia administrativa e pedagógica. A equipe escolar poderia participar da construção de sua própria história e, conseqüentemente, de sua própria escola. O planejamento nas escolas-padrão deveria ser o ponto principal para as decisões coletivas, ou seja, delinear o ideal a ser atingido e tomar decisões para a proximidade desse ideal. A proposta pedagógica implicaria a necessidade de se rever o conceito de currículo e nesta proposta, os objetivos, a seleção dos conteúdos e a metodologia usadas não poderiam ser pensados separadamente da avaliação. As Escolas-Padrão foram extintas na gestão Rose Neubauer em 1995-96. Disponível em: http://www.ime.unicamp.br/erpm2005/anais/c9.pdf. Acesso em: 03 de novembro de 2008.
} 
horas/semanais ${ }^{20}$. Apenas o professor coordenador do noturno, devido a uma carga horária menor de trabalho na coordenação, poderia, em outro período, continuar exercer a docência.

Conforme a Resolução SE n ${ }^{\circ} 35 / 00$, no seu artigo $2^{\circ}$, o docente designado para atuar como professor coordenador deveria:

I- $\quad$ Assessorar a direção da escola na articulação das ações pedagógicas desenvolvidas pela unidade [...];

II- Auxiliar a direção da escola na articulação dos diferentes projetos, inclusive os de reforço da aprendizagem;

III- Assessorar a direção da escola na relação escola/comunidade;

IV- Subsidiar os professores no desenvolvimento de suas atividades docentes;

V- Potencializar e garantir o trabalho coletivo na escola, organizando e participando das HTPCs;

VI- Executar, acompanhar e avaliar as ações previstas no projeto pedagógico da escola.

De acordo com os itens explicitados fica bastante evidente que a função do professor coordenador vinculava-se, diretamente, as ações do ensino e da aprendizagem, apoiando os professores e procurando garantir a aprendizagem de todos os alunos.

Para pleitear uma coordenação de escola, a mesma Resolução SE nº 35/00, em seu artigo $3^{\circ}$, definia os seguintes requisitos: ser portador de licenciatura plena, contar com, no mínimo, três anos de experiência como professor e estar vinculado à rede estadual como docente. Não havia na legislação exigência em relação a uma formação específica para atuar na função, como no caso de redes municipais, como a de São Paulo, onde é exigido que tenha concluído o curso de Pedagogia, sendo a coordenação cargo e não uma função.

Preenchendo os requisitos legais, o candidato a professor coordenador deveria submeter-se a uma prova para credenciamento junto a Diretoria Regional de Ensino. O candidato elaborava uma proposta de atuação e apresentava na escola em que gostaria de exercer a função. A indicação do candidato selecionado era feita pelo Conselho de Escola.

\footnotetext{
${ }^{20}$ O tempo de trabalho do professor coordenador do noturno era contabilizado levando em consideração o período das aulas mais o horário de trabalho pedagógico coletivo (HTPC), ou seja, as reuniões semanais que deveriam ocorrer sob sua coordenação.
} 
Também ficava ao encargo do Conselho de Escola, mediante uma avaliação do trabalho desenvolvido, a cessação da designação do professor coordenador.

Em outubro de 2006, a Secretaria de Educação publicou nova resolução que tratava da designação de professores para atuar na função de professor coordenador. A Resolução SE $n^{\circ}$ 66/06 não alterava as orientações da resolução anterior, apenas detalhava alguns aspectos e orientava nos procedimentos para designação dos interessados. Entretanto, é importante dizer que explicitava, nas considerações iniciais da resolução, a atuação do professor coordenador na formação continuada dos docentes, aspecto que estava apenas subentendido na resolução anterior.

Além de enfatizar o papel de formador do professor coordenador, a resolução, em seu artigo $2^{\circ}$, item VI, explicitava, como atribuição do professor coordenador:

[...] proceder, juntamente com os professores, a análise dos resultados da avaliação do desempenho escolar, através de seus indicadores, registrando e divulgando avanços e estratégias bem sucedidas, bem como identificando as dificuldades a serem superadas e propondo alternativas de otimização dos resultados.

Ao prever essa atribuição ao professor coordenador a Secretaria de Educação revela a importância dada a esse profissional no acompanhamento da avaliação da aprendizagem e na articulação com os resultados da avaliação externa, principalmente o SARESP. De algum modo, essas atribuições do professor coordenador justificam a escolha deste profissional como sujeito da pesquisa que fizemos.

No decorrer da pesquisa a SEE promoveu uma modificação na legislação em relação aos professores coordenadores. Essa modificação foi justificada pela SEE como necessária devido à importância que esse profissional passou a ter para a implementação da política educacional, como explicitado na Resolução SE 88/07: “a coordenação pedagógica se constitui em um dos pilares estruturais da atual política de melhoria da qualidade de ensino e os Professores Coordenadores atuam como gestores implementadores dessa política".

A Resolução $n^{\circ}$ 88/07 trouxe uma mudança, qual seja, a designação dos coordenadores por segmento e não mais por período. Dessa forma, os professores coordenadores passaram a trabalhar com um foco mais direcionado para as questões colocadas por cada segmento de ensino. Além disso, algumas escolas, devido ao número de turmas existentes, passaram a ter direito a mais de um professor coordenador por segmento, diminuindo, mais ainda, a sobrecarga de trabalho antes imposta aos coordenadores. 
Vale ressaltar também outras mudanças realizadas pela SEE. Uma delas foi o pagamento de um adicional pelo exercício da função de coordenação pedagógica, o que antes não ocorria. A outra foi no processo de escolha e seleção, apesar da manutenção da prova de credenciamento, houve a exclusão do Conselho de Escola no processo, ficando a responsabilidade apenas ao diretor e ao supervisor de ensino. Perdeu-se, portanto, com essa medida, a participação de professores, alunos, funcionários e pais na seleção, escolha e avaliação do trabalho do professor coordenador.

Devido às mudanças propostas pela SEE, todos os professores coordenadores que estavam atuando até o final de 2007 foram cessados da função no início de 2008, aqueles que pretendiam voltar para a coordenação deveriam se submeter a novo credenciamento e processo seletivo. Por isso, decidimos estruturar a pesquisa restringindo o recorte temporal ao ano de 2007. Essa decisão foi tomada porque, independente da permanência ou não do entrevistado na coordenação, ele falaria sobre o tempo em que permaneceu na função. Também não faria sentido entrevistar professores coordenadores que estivessem ingressando na função a partir de 2008, pois não teriam a vivência esperada da progressão continuada e do SARESP enquanto coordenadores.

Na Diretoria Regional de Ensino (DRE) onde foi realizada a pesquisa boa parte dos professores coordenadores conseguiu retornar para a função, mas houve mudanças de escolas e aumento no número de coordenadores, o que promoveu o ingresso de vários professores que ainda não apresentavam experiência nessa função.

\subsection{Manifestações registradas no questionário}

Neste item apresentamos e analisamos as manifestações dos professores coordenadores registradas no questionário. Foram aplicados questionários para 57 professores coordenadores pedagógicos que exerciam a coordenação em escolas localizadas em dois municípios da região metropolitana de São Paulo. Essas escolas estão subordinadas a uma mesma DRE.

Foi solicitado aos respondentes que identificassem o nome da escola para que pudéssemos fazer um contato posterior com alguns deles para a realização das entrevistas. 
Apenas um respondente não quis registrar o nome da escola em que exerce a função de professor coordenador.

O questionário foi respondido pelos professores coordenadores no mês de novembro de 2007, durante reunião com os assistentes técnicos pedagógicos, na DRE. A responsável pela reunião informou aos professores coordenadores que eles iriam responder a um questionário ao final da mesma.

Alguns professores coordenadores ficaram relutantes em responder prontamente ao questionário. Vários solicitaram levar o instrumento para responder posteriormente, devolvendo-o para a DRE que faria o encaminhamento do mesmo ao pesquisador. Mas, solicitamos que entregassem naquele momento mesmo, pois queríamos saber o que eles pensavam sobre as questões, sem que precisassem levantar dados na escola ou consultar o diretor.

Após as orientações e esclarecimentos, os professores coordenadores responderam ao questionário. Pudemos perceber que a maioria respondeu com interesse, não havendo problemas durante aplicação.

O questionário (ver Anexo I) é composto de duas partes. A primeira contém um levantamento do perfil dos professores coordenadores, objetivando identificar características pessoais ou profissionais que podem influenciar suas concepções e práticas.

A segunda parte apresenta três questões dissertativas, sendo que a segunda questão se desdobra em dois itens. A opção foi apresentar poucas questões visando deixar o respondente livre para registrar informações que considerasse relevantes e emitir suas opiniões. Além disso, seria mais provável ter sua aceitação para responder a um questionário que não fosse muito longo.

Apresentamos, inicialmente, os dados coletados sobre o perfil dos 57 professores coordenadores que responderam ao questionário. Do total de respondentes, 52 são mulheres e apenas 05 homens, sendo que a faixa etária da maioria varia entre 30 e 45 anos de idade.

Quanto à formação, todos possuem licenciatura, sendo em maior número professores de Língua Portuguesa, seguidos pelos professores de Ciências e Biologia. A quase totalidade dos professores se formou nos anos de 1999 e 2000. Além da licenciatura em área do conhecimento específica, 32 possuem Pedagogia, apesar de não ser uma exigência para o 
exercício da função de professor coordenador. O restante, que não tem Pedagogia, fez complementação pedagógica recentemente, entre 2004 e 2005. Quanto aos cursos de especialização, 14 fizeram algum curso, na maioria dos casos o curso foi relacionado à função de coordenador ou a sua área de formação.

O tempo médio que esses profissionais atuam na rede pública está entre 11 e 15 anos. Dos 57 professores, 30 são contratados e 27 são efetivos. Ressaltamos que a permanência dos profissionais na mesma escola contribui para que ele conheça seus problemas, os professores que nela atuam e tenha maior possibilidade de desenvolver um trabalho a longo prazo.

Entre os professores coordenadores efetivos, dois possuem mais de 11 anos na função e quatro tem 05 anos. Dos contratados apenas cinco estão acima de 05 anos. Identificamos professores coordenadores muito novos na função, com menos de 01 ano foram identificados nove efetivos e dez contratados.

O tempo na coordenação ou de magistério serve para balizarmos o quanto esses professores coordenadores têm convivido com as políticas de ciclo e progressão continuada e também com o SARESP, pois maior vivência pode significar maior experiência no trabalho com essas políticas.

Importante lembrar que os professores coordenadores que responderam aos questionários trabalham em escolas que oferecem o Ensino Fundamental. Não foram consultados os que atuam no Ensino Médio, porque não existe nesta etapa de ensino progressão continuada.

Dos 57 professores coordenadores, 25 coordenam escolas que são exclusivas de Ciclo I, 23 coordenam escolas que oferecem Ciclo II e Ensino Médio e nove coordenadores atuam em escolas que oferecem o Ensino Fundamental completo e o Ensino Médio. Essa situação indica que esses professores coordenadores atuam com uma diversidade muito grande de alunos, professores e turnos, o que pode gerar sobrecarga de trabalho e dificultar o desempenho na função.

O levantamento do perfil dos professores coordenadores que responderam ao questionário objetivava identificar algumas características que pudessem influenciar, de alguma forma, suas interpretações acerca das implicações da progressão continuada e do SARESP na avaliação escolar. Entretanto, os perfis analisados não permitiram essa 
identificação, o que se evidenciou nas respostas dadas pelos professores coordenadores, descritas a seguir, foi uma tendência comum em suas interpretações.

As informações e opiniões expressas pelos professores coordenadores foram tabuladas e registradas, anotando-se as iniciais de professor coordenador (PC) seguidas de um número atribuído a cada respondente. O critério para a numeração foi a ordem alfabética dos nomes das escolas coordenadas pelos PC.

A primeira questão que os professores coordenadores responderam foi: é comum entre professores, alunos e pais o comentário de que a implantação da progressão continuada gerou mudanças no modo como a avaliação é vivenciada na escola. Em sua opinião a progressão continuada trouxe mudanças na escola em que você atua? Relate o que vem ocorrendo.

Para que pudéssemos analisar as repostas dadas pelos professores coordenadores considerou-se, inicialmente, a primeira parte da questão, ou seja, em sua opinião a progressão continuada trouxe mudanças na escola em que você atua? Todas as respostas a essa pergunta foram afirmativas, todos disseram que a progressão continuada provocou mudanças nas escolas.

Os professores coordenadores que responderam ao questionário indicaram ter ocorrido mudanças na escola provocadas pela implantação da progressão continuada. A criação dos dois ciclos e a possibilidade de reprovação por rendimento escolar apenas no final de cada um deles desestabilizou o trabalho escolar na medida em que a implantação dos ciclos passou a ser compreendida por pais, alunos e professores como aprovação automática.

Os professores coordenadores atribuem o comportamento dos alunos e pais, após a adoção da progressão continuada, à falta de compreensão, ao entendimento errado do significado dessa medida.

Ao relatarem o que vem ocorrendo, que mudanças se processaram, tendo seu foco na avaliação, os professores coordenadores destacaram aspectos por eles considerados negativos, polêmicos e/ou contraditórios que essa medida gerou nas escolas. Esses comentários acerca das mudanças tiveram, essencialmente, como foco os professores, os alunos e os pais.

Um dos professores coordenadores afirmou que ocorreram "mudanças boas (positivas) e negativas, que surgiram devido a uma interpretação errônea da progressão continuada", provocadas, segundo ele, devido à "falta de informação para a comunidade". Indicou que a 
solução para esta questão seria "investir em informação" (PC18). Enquanto mudanças positivas ele citou a diminuição da reprovação e a necessidade de se repensar a forma de avaliar.

Esse entendimento "errôneo" da progressão continuada, para utilizar uma expressão dos próprios respondentes, promoveu o desinteresse dos alunos pelo estudo e pela aprendizagem, já que agora "todos passam de ano". O PC28 enfatizou que as mudanças promovidas pela implantação da progressão continuada foram "negativas, alunos estão saindo da escola sem estarem alfabetizados, pais reclamam que os alunos passam sem saber". O PC12 confirma essa opinião dizendo que "ainda há muita polêmica em relação à progressão continuada".

Segundo o relato dos professores coordenadores, os pais, apesar de fazerem severas críticas e reclamações à progressão continuada, pois seus filhos "passam sem saber", não se preocupam em acompanhar a vida escolar dos filhos, em incentivar que estudem, respeitem os professores e se dediquem à escola. Seguem alguns depoimentos que ilustram tal interpretação:

Os pais reclamaram muito, não concordando com a progressão continuada. (PC1)

Os pais, alunos, acham que vão passar de ano de qualquer forma, sabendo ou não. (PC9)

Devido à falta de informações, os pais acreditam que, de qualquer maneira, os filhos irão para a série seguinte e com isso há uma falta de compromisso dos pais com os filhos. Deixam de verificar seus cadernos, atividades, etc. Com esta falta de cobrança os alunos também se deixam levar por esta idéia e acomodam-se, gerando muita falta de compromisso e falta de interesse nas aulas. (PC23)

[...] alguns pais reclamam, não entendem, não aceitam o ciclo e seu processo. Pedem que seus filhos fiquem retidos ou algo similar. Sempre que necessário conversamos e explicamos sobre as mudanças. (PC4)

Em relação aos pais e alunos alguns ainda não conseguiram ter $\mathrm{o}$ entendimento completo, acreditando que sabendo ou não podem ser promovidos. (PC11)

Os pais criticam muito a progressão continuada, alegando que os filhos passam de ano sem saber. (PC20)

Os pais não aceitam a progressão continuada alegando que se estudar passa e se não estudar passa também. (PC5)

Os pais e alunos têm uma imagem de que não há necessidade de estudar, que passa. (PC21) 
O entendimento que os pais têm da progressão continuada, expressos nas opiniões manifestadas pelos professores coordenadores, revelam que essa dificuldade advém da compreensão que as famílias têm do processo de escolarização. Os pais, mesmo aqueles que não tiveram oportunidade de frequentar a escola, têm um entendimento de como ela deve funcionar. Para eles, a escola deve funcionar nos moldes que tradicionalmente funcionou no Brasil, ou seja, adotando uma organização seriada e decidindo no final do ano acerca da aprovação ou não dos estudantes. A aprovação ou reprovação se definiria a partir do rendimento do aluno, verificado pelas notas que o conseguiu nas avaliações realizadas durante o ano letivo.

No contexto da progressão continuada, em que a avaliação não serve mais para essa função, é compreensível que os pais concluam que agora todo mundo passa e que a avaliação não serve para nada. É nesse sentido que alguns professores coordenadores indicaram ações que estão promovendo, objetivando esclarecer os pais acerca da progressão continuada e do papel que a avaliação deve assumir a partir da sua implantação:

\begin{abstract}
Alguns pais ainda não entendem, então, nas reuniões, procuramos explicar para eles que a temporalidade das crianças é diferente, que nem todos os alunos aprendem ao mesmo tempo. Todos precisam aprender, mas as classes têm crianças de todos os tipos e o respeito para com elas tem que ser mantido. (PC7)

Percebo que os pais já estão sendo conscientizados de que as "notas bimestrais" não são mais importantes quanto antes, mas sim os relatos do professor. Mudanças de comportamento dos alunos hoje são os principais meios para esta avaliação. (PC6)

Infelizmente, alguns pais não entendem que a progressão continuada é uma forma de avaliar o aluno dentro de suas habilidades. Ainda persiste a concepção de que o aluno deve ser "dez" em todas as disciplinas. (PC3)
\end{abstract}

A incompreensão de alguns pais se revela também em ações para impedir que seus filhos sejam promovidos pela escola sem efetivamente terem aprendido, conforme relato do PC19:

A progressão continuada, na visão dos pais, é uma aprovação automática, sem uma avaliação apropriada do aluno. Por várias vezes, temos pais querendo a retenção do educando, preferindo até conversar com a Dirigente para que este aceite a retenção do seu filho. Em conversa com os responsáveis, percebemos a insatisfação diante da progressão.

Se por um lado, alguns professores coordenadores relataram avanços dos pais no sentido de compreenderem melhor a idéia contida na progressão continuada e o significado da avaliação nesse contexto, por outro, também se manifesta a idéia de que a 
escola, em muitas situações, não pode contar com a ajuda dos pais para orientarem e apoiarem o trabalho da escola:

[...] a pouca atenção que a família dá aos filhos. Os pais dizem que não concordam com a Progressão continuada, mas não estimulam os filhos a estudarem. (PC49)

[...] percebemos a ausência da família na ajuda aos filhos, deixando a critério da escola todas as funções que cabem aos pais orientar e participar da vida escolar do educando. (PC54)

Os pais estão insatisfeitos, pois até hoje não sabem o que significa a progressão continuada, apenas culpam o professor por seu filho estar "passando de ano sem saber ler e escrever". (PC2)

[...] os pais pouco podem fazer, uma vez que a escola orienta que o filho será aprovado, pois o que não conseguiu assimilar esse ano, no próximo será resolvido, o que não tem acontecido [...] Os pais vêem os problemas e não conseguem resolver nem mesmo os problemas com a educação em casa, quanto mais esta tarefa. (PC27)

Em um dos relatos o professor coordenador fez menção a outras políticas governamentais que interferem na relação da família com a escola, agravando ainda mais o problema:

O que vem ocorrendo em minha U.E., por parte das famílias, (de alguns) é o interesse no dinheiro da Bolsa Família, e não no aprendizado do filho. Muitas só procuram a escola quando a bolsa é interrompida. Mesmo quando mandamos convocação para falar sobre o rendimento ou desempenho do aluno os responsáveis nem aparecem porque sabem que seus filhos vão passar de série. Até mesmo no final do ciclo o interesse é muito pequeno. (PC32)

Portanto, nas respostas dadas pela maioria dos professores coordenadores fica latente a dificuldade em lidar com a tradição escolar, com a cultura da repetência, como bem explicitado por um dos professores coordenadores ao falar das decorrências da implantação da progressão continuada no cotidiano escolar:

A implementação da progressão continuada gerou muitos problemas. Durante muitos anos a cultura da retenção permeou o espaço escolar. E isso fez com que a avaliação se tornasse um instrumento de punição e não ponto de partida para promover a aprendizagem. (PC14)

Essa fala revela que há profissionais da rede que vêm se apropriando das críticas que são feitas às práticas avaliativas tradicionais e à reprovação. Entretanto, apesar disso, não podemos esquecer o desafio que se coloca para os profissionais da educação que busquem fazer mudanças na escola, alterando uma estrutura cuja base, tradicionalmente, se situa na aprovação/retenção do aluno ao final de cada ano letivo. 
A opinião dos professores coordenadores a respeito das mudanças que a progressão continuada provocou nos alunos não é muito animadora. Segundo eles, muitos alunos estão cada vez mais desestimulados, desinteressados e, já que passam de ano mesmo sem estudar, não querem fazer as atividades propostas, como indicam esses depoimentos:

A progressão continuada hoje é vista como promoção automática por muitos alunos, o que acarreta certo descaso aos estudos. Infelizmente, essa visão dos alunos tem dificultado o trabalho do professor em sala de aula, pois percebemos que há uma parcela de jovens saindo da escola com pouco conhecimento. (PC40)

[...] o aluno não quer, muitas vezes, fazer nada, pois acha que não será reprovado, basta estar presente. (PC9)

Os alunos não têm compromisso em estudar. (PC13)

Os nossos alunos não estão culturalmente preparados para essas mudanças. (PC14)

Os alunos acham que não precisa estudar, a cobrança é só a presença. Desta forma, os pais e a sociedade estão muito mal informados. (PC24)

O que se pode observar no comportamento dos alunos é que, na grande maioria, perdeu-se a responsabilidade e o comprometimento com a sua formação. Adquirindo conhecimento ou não ele será promovido. Desta forma gerou o sentimento de que seria praticada a promoção automática. [...] O aluno, a cada ano, vai ficando defasado no seu conhecimento. A escola não tem conseguido trabalhar para resolver a defasagem de aprendizagem. (PC29)

O nosso maior problema é a falta de compromisso dos alunos com o estudo. (PC49)

A progressão continuada, infelizmente, deixou o aluno mais acomodado, faz pouco e obtém resultado positivo sempre. (PC47)

O relato do PC14, citado anteriormente, situa as dificuldades enfrentadas pelos alunos no entendimento da progressão continuada, na cultura escolar, marcada, na maioria das vezes, pelo uso da avaliação como instrumento de controle da sala de aula, da disciplina dos alunos e "mola propulsora" da aprendizagem. Romper com essa cultura é muito difícil, pois, como evidencia Vasconcellos (1998):

Historicamente a função docente foi sendo associada ao controle, à fiscalização, ao disciplinamento, à medida, à verificação, a tal ponto que para muitos professores sua principal tarefa passou a ser transmitir os conteúdos e logo constatar o quanto os alunos assimilaram, indicando claramente, através de notas, conceitos ou menções, quais são os "aptos" ou "inaptos", ou seja, aqueles que não merecem prosseguir nos estudos por "não terem condições" ou por "não saberem aproveitar as iguais oportunidades dadas a todos."(p. 23) 
Ao se alterar a finalidade da avaliação, não visando aprovar ou reprovar o aluno, mexeu-se na viga mestra que estruturou nossa escola durante séculos. Essa lógica se instaurou objetivando atender determinada sociedade em um dado contexto histórico de consolidação de uma sociedade liberal e capitalista. A escola que emergiu nesse contexto criou determinados processos de funcionamento que estão impregnados no modo de se pensar a escola ainda hoje. Segundo Freitas, a escola desvinculou-se do mundo real, criando em seu interior um mundo à parte. Para adequar o alunado a esse mundo estabeleceu mecanismos artificiais de controle:

A necessidade de introduzir mecanismos artificiais de avaliação (prova, testes, etc.) foi motivada pelo fato de a vida ter ficado do lado de fora da escola. Com isso, ficaram lá também os motivadores naturais para a aprendizagem, obrigando a escola a lançar mão de motivadores artificiais foi desenvolvido um sistema de avaliação com notas como forma de estimular a aprendizagem e de controlar o comportamento de contingentes cada vez maiores de crianças que acudiam à escola e tinham de ficar dentro delas, imobilizadas, ouvindo o professor. $\mathrm{O}$ isolamento e o artificialismo da escola levaram a uma avaliação igualmente artificial. (FREITAS, 2003, p.27-28)

A implantação da progressão continuada, consistindo na retirada de elementos desse artificialismo da escola, incidiria de alguma maneira no comportamento dos alunos, como demonstraram os relatos dos professores coordenadores. Além dessa ruptura com a tradição escolar, marcada pela cultura da repetência, também nos deparamos com um aluno que, independente das mudanças promovidas no interior das escolas em relação às formas de progressão, é diferente, bombardeado por um mundo tecnologicamente ágil, que lhe proporciona outros atrativos, por questões familiares, sociais e sem muitas perspectivas de um futuro promissor, conquistado graças à escola, como explicitado por alguns professores coordenadores:

Quanto aos alunos, no meu ponto de vista, dentro da realidade escolar, estão na média de $60 \%$ despreparados, deseducados e carentes; praticamente sem base familiar e sem compromisso escolar, acreditando que o ano letivo passa e eles estudando ou não passarão também. (PC54)

O aluno, esse não está nem aí, apenas estão preocupados com o computador, o MP 3 e seus direitos, pois esses sim foram bem divulgados para pais e alunos. (PC2)

Esse contexto mais geral, aliado a progressão continuada, faz "com que o aluno se acomode e não se preocupe com as avaliações, não levando a sério o trabalho dos professores e os estudos de forma geral". (PC46) Entretanto, se "a maioria gostou dizendo que é só não faltar, existe uma minoria que já não concorda e se preocupa com sua formação e seu aprendizado". (PC1) Sendo assim, a progressão continuada coloca as escolas numa situação 
de desestruturação, de desestímulo, diante da necessidade de repensar sua função, seu papel, num contexto, na maioria dos casos adverso, como enfatizado por dois coordenadores:

A quantidade de alunos na sala de aula dificulta o atendimento individual do aluno para suas intervenções, às vezes não é um problema de aprendizagem, mas sim clínico; deveria ter nas escolas especialistas (psicopedagogo) para atender as dificuldades do aprendizado dos alunos. (PC12).

Apesar do esforço da Secretaria de Educação em maquiar o sistema, os alunos passam sem saber ler e escrever e temos alunos descompromissados e o rendimento caiu demais. Apesar dos esforços para reverter esse problema, os professores estão desmotivados por essa política educacional e os baixos salários. (PC57)

Portanto, há a necessidade não apenas de informar, orientar, compreender, mas de criar condições estruturais, como, por exemplo, o apoio de outros profissionais que possam auxiliar os profissionais da escola no trabalho pedagógico com todos os estudantes.

Se a reprovação explicitava o fracasso escolar, a progressão continuada, de acordo com o relato de um professor coordenador, permite que o fracasso ocorra em outros moldes, escamoteado pela progressão dos alunos na trajetória escolar. Assim se expressou o professor:

Existem vários casos de alunos que passam para a série posterior sem possuírem habilidades e competências necessárias para um bom acompanhamento da mesma. Isso acarreta algumas outras dificuldades neste ano posterior e assim sucessivamente. É como se ele tivesse perdido o fio da meada e, sempre, embora aparentemente acompanhe as séries, carregam com eles a sensação de "aluno com dificuldade". (PC31)

Os relatos dos professores coordenadores, em sua maioria, acerca do desinteresse e desestímulo dos alunos em função da progressão continuada, de certa forma, não colocam o problema na progressão continuada, mas na reação dos alunos frente a não reprovação em determinadas séries. Esse desinteresse dos alunos gera, inclusive, a desmotivação dos professores, como aponta o PC32: "o interesse por parte dos alunos no aprendizado diminuiu muito e até mesmo o estímulo de alguns professores".

Esses depoimentos revelam, a princípio, uma culpabilização dos alunos pelo seu desinteresse, mesmo que ele seja proveniente da implantação da progressão continuada, o que indica a manutenção de uma situação que já se verificava tradicionalmente na cultura escolar, marcada pela repetência. Nesse sentido, Freitas (2003, p. 82) alerta que "essa forma de operar faz com que a exclusão se faça, de fato, segundo a bagagem cultural do aluno, permitindo que ela ocorra no próprio interior da escola e de forma mais sutil [...] responsabilizando o aluno por seus próprios fracassos.” Essa situação se evidenciou nos seguintes relatos: 
[...] temos alunos que chegam ao Ensino Médio com muita dificuldade de leitura/interpretação e sem noção da base em matemática. Mesmo os alunos que participaram da RA (Recuperação da Aprendizagem) não demonstram progressos. O fator "passa de ano sem saber nada", fez com que o aluno se acomodasse, não tem mais a vontade de tirar uma boa nota, vencer. (PC21)

Efetivamos diversos desdobramentos para que ela ocorra, entretanto a falta de compromisso do aluno com a aprendizagem e da família não consegue mudar a postura do filho, tem acarretado muitas indignações por parte do professorado. Sinto que este sistema educacional criou uma geração acostumada a passar por um processo de recuperação e que a anestesiou, afinal uma parcela do alunado não tem responsabilidade com os estudos. (PC14)

A maioria dos relatos dos professores coordenadores revela uma desmotivação dos professores gerada pela implantação da progressão continuada e pelo desinteresse dos alunos pela aprendizagem. Segundo o PC2 os "professores (as) estão descontentes com o sistema devido ao fato de que não foram consultados, orientados, capacitados ou ainda estruturados para exercer e trabalhar com essa mudança".

Alguns professores coordenadores fizeram os seguintes relatos:

PC9- Trouxe muitas mudanças na escola sim, principalmente entre alguns professores que não sabem como trabalhar isso [...].

PC10- As mudanças que tivemos na escola é que não existe mais retenção. Porém, o trabalho e a forma que deveria ser trabalhado segundo a concepção da progressão continuada não vêm acontecendo por vários fatores.

PC19- Na opinião dos educadores a progressão veio piorar a indisciplina e na falta de respeito com o educador.

PC25- A progressão continuada trouxe mudanças na escola em que atuo. Infelizmente, entre a maioria dos professores ainda há uma visão negativa em relação a essas mudanças. A principal elencada pelos professores é a falta de interesse e comprometimento de muitos alunos com o processo de ensino-aprendizagem, devido à persistente concepção da progressão continuada tratar-se de uma "aprovação automática" (na visão de muitos pais e alunos).

PC31- Por várias vezes esse assunto foi colocado em pauta, principalmente nas reuniões de HTPC, onde o professor coloca a culpa da indisciplina, da falta de interesse dos alunos na progressão continuada.

PC36- Quanto aos professores, o envolvimento também não é fácil. Apesar do empenho durante os HTPCs, formação continuada, ainda existem resistências, mas sem que ao menos reflitam sobre a importância da progressão continuada.

PC43- Percebo que muitos educadores se descomprometem com a qualidade do ensino, argumentando que de um jeito ou de outro a criança será aprovada. Isso surte um efeito negativo no aprendizado. 
PC47- O professor é muito resistente e por conta de " $n$ " dificuldades rejeita a progressão continuada que poderia ser boa.

PC54- Os professores ainda sentem dificuldades e falta de segurança com relação a vários aspectos da progressão.

De acordo com as manifestações mencionadas, existem muitos problemas que foram gerados a partir da implantação da progressão continuada. Segundo esses relatos os professores que se posicionam contrariamente a progressão continuada o fazem por vários motivos. Um motivo explicitado pelos professores coordenadores foi o modo de implantação da progressão continuada, de forma impositiva pela Secretaria de Educação, sem orientação e discussão prévia com o professorado, gerando incompreensão e resistência à medida adotada. Essa situação, mencionada pelos professores coordenadores, foi identificada em várias pesquisas feitas sobre o tema, como mencionadas no capítulo anterior. Seguem-se depoimentos dos professores coordenadores sobre este ponto:

Desde a implantação da progressão continuada, desconheço momentos ou encontros com a comunidade escolar para pontuar seus benefícios, principalmente no item avaliação, no qual particularmente acredito ser valioso, pois se rompeu a barreira da discriminação da repetência. (PC36)

A progressão continuada deveria ter sido trabalhada com pais, alunos e professores antes de ser implantada, pois, da forma que foi feita, esta implantação gerou certa irresponsabilidade nos alunos, pais e, conseqüentemente, professores ficaram desmotivados, pois não sentiram mais interesse por parte dos alunos em estudar. (PC37)

A resistência, a incompreensão ou a dificuldade de entender a progressão continuada não se restringem somente a isso, como o relatado anteriormente, mas a sensação da perda de poder, de dificuldade de controlar a disciplina dos alunos e gerar motivação para o estudo e para a aprendizagem. A progressão continuada afetou diretamente os professores. Ao perderem a moeda de troca, de controle, de motivação, ou seja, o temor da reprovação, muitos professores ficaram sem norte para o desenvolvimento de seu trabalho, como enfatiza o PC29: "estamos perdendo o rumo da situação e ficaremos sem prumo".

Entretanto, a busca por algum "rumo" e a tentativa de colocar um "prumo" nessa situação de "desencanto", "desestímulo" e "desmotivação" também foi revelada em respostas dos professores coordenadores. Essa busca pela compreensão da medida, por cursos e capacitações, por alternativas metodológicas, por estratégias de recuperação ou pela revisão dos conteúdos trabalhados, por mudanças mais positivas, tentando encontrar algum modo de enfrentar os desafios postos pela progressão continuada, pode ser evidenciada nos depoimentos a seguir: 
Através de aulas diversificadas [...] a ida a sala de computação tem ajudado bastante, mas ainda não conseguimos sanar todos os problemas. (PC7)

[...] quando ali cheguei já havia uma estruturação e o entendimento do que é a progressão continuada, para que veio, pois é uma escola onde os educadores do Ciclo I são todos efetivos, fizeram o curso Letra e Vida, portanto, têm uma visão ampla de como trabalhar. Em relação ao Ciclo II, os professores procuram, a todo instante, estar se capacitando durante os HTPCs, nos cursos e leituras em particular. (PC11)

[...] houve mudança significativa, levando o professor a refletir sobre sua postura profissional. (PC12)

Os professores mudaram sua maneira de pensar e agir, estão buscando novos conhecimentos para melhorar a qualidade do ensino. (PC22)

Os professores hoje encaram a progressão continuada de uma forma mais harmoniosa fazendo adequações no seu sistema de ensino, porém verifica-se ainda a necessidade de mudança. (PC27)

Alguns professores coordenadores explicitaram alterações que são promovidas na escola e que estão, mesmo que lentamente, possibilitando que se superem as dificuldades na implantação da progressão continuada. Para isso os professores têm aproveitado os poucos espaços coletivos de discussão para trocar experiências, estudar, buscar informações, procurando minorar os efeitos negativos da progressão continuada e valorizar pontos considerados positivos. Dentre esses pontos, houve destaque às discussões feitas pelos professores acerca das consequências negativas da reprovação escolar, como ilustram os seguintes depoimentos:

Apesar de não ter experiências anteriores a progressão continuada, percebo que trouxe mudanças pela fala de professores mais antigos na rede. $\mathrm{O}$ que ocorre é que muitos reclamam da suposta ausência da avaliação tradicional que leva a suposta idéia de que não há mais repetência. No entanto, outros estão tomando consciência, estudando e se adequando a esse "novo" contexto, isso fica claro quando nos HTPCs discutimos avaliação; a resistência está sempre nos professores que fazem parte do $1^{\circ}$ grupo que descrevi. (PC41)

Antes da progressão continuada os alunos ficavam retidos por vários anos. Hoje eles contam com a RC (Recuperação de Ciclo) um tipo de recuperação e são avaliados durante todo o ano letivo e não apenas ao final de cada bimestre como era antes com provas bimestrais. Na maioria dos casos os alunos ficavam com 12 até 13 anos na $1^{\text {a }}$ série e acabavam desistindo da escola. Com a avaliação diária, eles são acompanhados no ano seguinte e partem de onde eles precisam. (PC48)

Com a progressão continuada, na minha escola, a visão do professor em relação ao desenvolvimento da aprendizagem do aluno tem um foco em avanços, pois o mesmo precisa ter claro o que o seu aluno sabe, qual conhecimento ele já construiu, suas idéias, para que ele faça um planejamento de conteúdos e estratégias de acordo, para que esse aluno 
avance em seus saberes e com a aprendizagem eficaz. Assim, os alunos que eram retidos ou evadidos se sentem motivados a frequentar a escola, pois percebem que são capazes e podem aprender quando o trabalho da escola propõe um currículo com atividades desafiadoras, porém possíveis de serem realizadas proporcionando o avanço de todos. (PC55)

Alguns professores coordenadores procuraram evidenciar mudanças nas práticas avaliativas de forma mais específica, demonstrando que pequenas mudanças são desencadeadas e, com o tempo, podem tornar-se significativas. Os relatos que se seguem evidenciaram que, muitas vezes, existe uma dificuldade dos professores pensarem sobre o papel da avaliação no contexto da progressão continuada e, mais do que isso, de por em prática uma avaliação formativa:

Os professores ainda não estão preparados para trabalhar o global e avaliar continuamente os educandos. (PC15)

Na visão dos professores a progressão continuada não é de todo ruim, apenas deveria ter algumas modificações e dar mais autonomia para o professor que acompanha o aprendizado dos alunos, em relação à avaliação final do mesmo. (PC20)

Percebo que os professores não focam o que o aluno não adquiriu e sim o que os alunos já adquiriram; que esta avaliação agora serve de diretriz para planejar as ações seguintes. (PC6)

Apesar das dificuldades serem grandes, o empenho no sentido de repensar as práticas avaliativas pode, lentamente, minimizar os impactos negativos da progressão continuada, conscientizar professores, alunos e pais dos problemas que a reprovação acarreta para o aluno, a escola e a sociedade. Esse movimento se revelou nos depoimentos de alguns professores coordenadores:

Percebo que os pais já estão sendo conscientizados de que as "notas bimestrais" não são mais importantes quanto antes, mas sim os relatos do professor, mudanças de comportamento dos alunos hoje são os principais meios para esta avaliação. (PC6)

Temos percebido mudanças gradativas no desempenho dos alunos através das avaliações diagnósticas realizadas no cotidiano escolar. (PC35)

[...] são avaliados durante todo o ano letivo e não apenas ao final de cada bimestre como era antes com provas bimestrais. Com a avaliação diária, eles são acompanhados no ano seguinte e partem de onde eles precisam. (PC48)

As atividades desenvolvidas passaram a ser feitas em duplas ou grupos e com isso os alunos perderam o sentido da necessidade de se avaliar através de provas. Acredito que as avaliações são importantes para a melhoria da qualidade do ensino. (PC50) 
O PC16 fez um relato de uma mudança na avaliação que, na verdade, revela que, às vezes, o que se procura é dar respostas aos anseios dos pais e alunos, inclusive dos professores, por meio do fortalecimento de práticas antigas, mas com uma "roupagem" nova:

Conseguimos ouvir diversas opiniões em relação à progressão continuada; pais que dizem que os professores não aplicam provas, professores que dizem que a prova não é mais necessária, pois os alunos irão ser promovidos para a série seguinte. A escola pedagogicamente assumiu e acolheu estas opiniões em forma de questionários para a comunidade e professores. Uma de nossas ações para que a avaliação cumpra o papel de ser norteadora do nosso trabalho foi termos calendários para as nossas avaliações e enviarmos aos pais, criamos também a avaliação unificada ( 2 questões dissertativas de cada disciplina). (PC16)

Esse relato indica a criação de estratégias para demonstrar aos pais e alunos a necessidade e a existência das provas. Não podemos dizer que a criação dessa estratégia represente um avanço em direção a uma prática formativa de avaliação, pois o relato não explicita o uso dos resultados dessa avaliação unificada, apenas sua existência e a tentativa de responder aos anseios da comunidade escolar. Por outro lado, também não podemos simplesmente desqualificar a iniciativa, já que ela aponta para a busca de solução e encaminhamentos às dificuldades geradas pela implantação da progressão continuada.

Um relato aproximou a avaliação da aprendizagem da avaliação externa. Observamos que essa aproximação deu-se mais no sentido de mostrar que as avaliações externas mantêm uma credibilidade maior perante os alunos do que os processos de avaliação realizados pela escola. Talvez isso ocorra porque os primeiros se centrem em provas e testes, enquanto a avaliação nas escolas se utilize de uma variedade maior de instrumentos e, em alguns casos, como foi relatado, as provas são deixadas de lado:

É importante ressaltar que o interesse pela avaliação por parte dos alunos, caiu muito e isso eu percebo na minha escola; eles têm muita preocupação quando a avaliação vem de fora, como: Olimpíada de Matemática, SARESP, ENEM, entre outras. (PC31)

Pode ser que a situação explicitada anteriormente tenha explicação nas práticas avaliativas tradicionais, que atribuíram centralidade às provas, o que faz com que os alunos, mesmo após tantos anos de progressão continuada, se sintam em situação de avaliação quando fazem provas.

Outro aspecto a ser ressaltado nos relatos é a posição do professor coordenador em relação à progressão continuada. Nenhum deles explicitou ser favorável ou não a introdução dessa medida na rede de ensino estadual e sempre, quando se referiram às resistências, a falta 
de entendimento, ao desestímulo ou a falta de compromisso, tomaram como referência reações de pais, alunos e professores.

Além disso, apenas dois professores coordenadores explicitaram seu papel na escola, coordenando o trabalho pedagógico e, portanto, assumindo a responsabilidade de promover ações para orientar professores, alunos e pais em relação a essa medida:

Nós, da equipe de gestão e eu, em particular, vamos orientando e tirando esse rótulo tão negativo. (PC31)

Estamos trabalhando, ainda, para desvincular o termo progressão continuada de promoção automática. [...] Embora tais mudanças já estejam, há algum tempo, sendo trabalhadas, ainda há muito trabalho de conscientização que precisamos desenvolver com os alunos (sala de aula), professores (HTPC), pais (reuniões de pais e mestres) sobre o assunto. (PC39)

No tocante às ações dos órgãos superiores não há referências a iniciativas que tenham ocorrido no sentido de apoiar a escola e o trabalho do professor coordenador na condução de ações que orientem as práticas avaliativas no contexto da progressão continuada. Apenas um professor coordenador explicitou o apoio da Diretoria Regional de Ensino, na figura dos assistentes técnicos pedagógicos (ATP), relatando que "as ATPs têm nos ajudado bastante nos orientando, dizendo que nós não estamos sozinhos" (PC7).

As respostas dadas pelos professores coordenadores para a primeira questão do questionário revelam que há ainda muitas dificuldades oriundas da implantação da progressão continuada. Algumas mudanças vêm se processando de maneira incipiente, principalmente nas práticas avaliativas, o que nos permite inferir que, após mais de uma década de adoção dessa medida existe certa acomodação, caracterizando a resistência como algo passivo, sem reação contrária, pois a SEE não tem dado respostas ao descontentamento manifestado pela rede.

A situação de descontentamento, no interior das escolas, tem provocado um movimento de acomodação, de cristalização de práticas, de renovação de outras e do surgimento de iniciativas de mudanças na avaliação e na aprendizagem. Portanto, após mais de dez anos de progressão continuada, a escola e a avaliação não são as mesmas.

A segunda questão que consta do questionário aplicado aos professores coordenadores se relaciona a avaliação externa, ao SARESP, e se desdobrava em dois itens. O primeiro deles indagava sobre: como a escola vem utilizando os resultados do SARESP? 
Neste item da segunda questão as respostas, majoritariamente, não explicitavam como os resultados do SARESP eram utilizados, mas em que momento isso ocorria. A maioria dos professores coordenadores disse que os resultados do SARESP são utilizados durante os momentos de planejamento, no início do ano, e no replanejamento, no início do segundo semestre letivo. Disseram, também, que os dados servem para orientar os professores na elaboração dos planos de ensino e de aula, identificando as dificuldades que os alunos apresentam e estruturando o trabalho pedagógico para minimizar as dificuldades detectadas por meio do SARESP, como indicam os seguintes depoimentos:

Nos planejamento e replanejamento com a utilização dos dados pelo corpo docente na elaboração das ações e planos de ensino para a melhoria do processo do ensino-aprendizagem. (PC15)

Durante o planejamento são colocados em pauta os resultados e planejado para durante o ano trabalhar as dificuldades apresentadas. (PC34)

Os resultados servem como eixo para o planejamento e ao mesmo tempo mostram como está o ensino-aprendizado na U.E. (PC42)

Através dos resultados são traçadas metas para sanar as dificuldades (no planejamento). (PC10)

Utilizamos os resultados do SARESP em nosso planejamento como ponto de partida para a elaboração de plano de ensino e de como estarmos trabalhando durante o ano com nossos alunos, com o objetivo de alcançarmos um resultado melhor no próximo ano, tanto no SARESP como no seu aprendizado durante o ano. (PC1)

Utilizamos os resultados todos os anos no planejamento anual. Os dados trabalhados servem de parâmetro para detectar onde os alunos encontram dificuldades. (PC3)

Apesar de não explicitarem como os resultados são utilizados durante o planejamento ou replanejamento, a maioria dos professores coordenadores respondeu de modo afirmativo, indicando que os dados coletados no SARESP permeiam o trabalho escolar.

Alguns professores coordenadores foram mais explícitos nas respostas dadas, revelando uma maior influência do SARESP como indicador para ações de planejamento, estabelecimento de metas, objetivos e orientação do trabalho pedagógico, identificando-se as habilidades que precisam ser mais desenvolvidas. Os depoimentos que se seguem são reveladores dessa tendência:

São utilizados como indicadores durante o ano letivo, para referência a cada bimestre. Durante o planejamento e o replanejamento serve como indicador para rever as ações da escola para que possamos alcançar as metas traçadas, 
para alcançar os objetivos do grupo quanto ao processo de ensinoaprendizagem. (PC2)

Procuramos novas ações para desenvolver as habilidades que os alunos encontram dificuldade (nem todos os educadores executam esse recurso, resultados ou provas anteriores). (PC6)

São utilizados como um norteador a mais na análise da prática docente. (PC43)

Nós utilizamos, é mais um instrumento para nortearmos nosso trabalho. Temos uma grande troca anual do corpo docente, então, no planejamento, os novos docentes já têm uma prévia noção do que priorizar em seus planos. (PC16)

O último relato, do PC16, revela que o SARESP, no caso desta escola, tem uma importância grande no sentido de ser referência para a organização do planejamento no início do ano letivo. Devido à troca de professores de um ano para outro o SARESP cumpre a função de informar os professores novos da escola sobre as dificuldades dos alunos, ao menos na avaliação externa. Portanto, dependendo da realidade de cada unidade escolar e de como a escola lida com os resultados, a avaliação externa pode assumir maior ou menor importância.

Poucos foram os professores coordenadores que procuraram indicar como os dados são utilizados. Os que o fizeram também não aprofundaram muito em relação a procedimentos, mas podemos deduzir que, na maioria das vezes, as análises são feitas de modo mais global, fazendo o uso de gráficos e tabelas. Revelam, ainda, a intervenção na prática, principalmente através do uso das questões que são utilizadas nas provas do SARESP e do desenvolvimento das habilidades que são testadas, como indicam os depoimentos:

No planejamento são colocados cartazes com a progressão que as salas tiveram e o que ainda precisa ser melhorado no decorrer do ano letivo. (PC7)

Os resultados do SARESP e da avaliação interna são utilizados em reuniões de planejamento e replanejamento. Eles são apresentados em forma de gráfico e, desse modo, são traçados as metas da escola. (PC14)

No planejamento fazemos levantamento das habilidades que obtiveram 50\% abaixo da média. Com isso, formamos grupos de professores por sala, adaptando os exercícios propostos do SARESP, trabalhando as dificuldades nas habilidades propostas no SARESP. (PC53)

Em nossa U.E. a prova vem sendo utilizada e trabalhada em sala de aula. No planejamento o professor analisa os resultados para poder elaborar seu plano de aula. (PC19)

Os depoimentos dos professores coordenadores indicaram que o uso dos resultados do SARESP na escola tem influenciado na conformação das práticas avaliativas, pois tem 
servido de modelo para a criação e utilização de simulados, provões, tanto com o intuito de preparar os alunos para o SARESP, como para melhoria da aprendizagem:

Utilizamos e, além do SARESP, no ano passado que não tivemos esta avaliação fizemos uma avaliação interna nos moldes do SARESP, com todos os dados computados conhecendo as dificuldades dos alunos. Esses dados foram passados em gráficos de todas as séries; manhã, tarde e, por fim, um gráfico geral que foi trabalhado no planejamento de 2007 e elaborado o plano de ensino, contemplando esses dados. (PC9)

Com certeza, inclusive neste ano existe avaliação unificada. (PC11)

Nós avaliamos os resultados no início do ano no planejamento e colocamos metas para serem atingidas durante o ano letivo. Utilizamos as avaliações (SARESP) e trabalhamos com os alunos, colocando os pontos negativos e tentando sanar as dificuldades encontradas, além de fazer durante o ano provas semelhantes. (PC31)

É através das provas SARESP que vem fortalecendo o grupo e servindo de subsídio para o planejamento e replanejamento e estar durante o ano aplicando atividades do SARESP como simulados e analisar no final do ano gráfico para avaliar de onde devemos estar retomando a nossa prática. (PC12)

Os relatos que se seguem indicam que, em algumas escolas, os dados do SARESP são comparados com os anos anteriores e também que há uma preocupação com outras avaliações externas, além do SARESP. Isso revela que as avaliações externas, de algum modo, vêm impactando o trabalho escolar, o que precisamos identificar com maior precisão são as finalidades das iniciativas desencadeadas:

Comparamos os resultados com os anos anteriores. Destacamos quais habilidades/competências precisam ser mais trabalhadas. Inserimos nos planos de ensino as ações e conteúdos necessários para tal fim. Desenvolvemos estudos com alunos desde o início do ano letivo, visando às avaliações externas, incluindo ENEM. (PC20)

Os resultados são analisados e discutidos em reuniões pedagógicas como HTPC. Fazemos várias reflexões e utilizamos as avaliações do SARESP anteriores como base e estudo para os próximos anos letivos e próximos SARESP. (PC54)

Um professor coordenador fez referência à alteração da proposta pedagógica a partir dos resultados da avaliação externa, indicando a dimensão que a avaliação externa vem assumindo na escola. A alteração na proposta pedagógica foi relatada pelo PC23: “os resultados obtidos são utilizados para a análise do nosso trabalho e a partir daí são traçadas novas metas, metodologias diferenciadas e o que precisa ser revisto dentro da proposta pedagógica da escola para que o processo ensino-aprendizagem tenha êxito" (grifo meu). 
Apesar da maioria das respostas a questão 2, item a, indicarem uso dos resultados do SARESP, mencionando, inclusive, alterações na prática, não deixaram de surgir relatos, dos professores coordenadores, que se referissem à resistência ao SARESP. Apenas os relatos que se seguem questionaram o SARESP, afirmando, inclusive, que a avaliação não condiz com a realidade dos estudantes de determinadas escolas e fazendo algumas outras críticas:

Analisamos as habilidades/competências que os alunos tiveram dificuldades e dentro do planejamento anual "tentamos" trabalhar. Digo tentamos porque não retrata a realidade da escola, por mais que a orientação seja dada, os alunos ficam nervosos, muitos "chutam" as respostas, e muitas vezes a própria prova está muito além do que trabalhamos com nossos alunos. (PC21)

O grupo rejeita esses indicadores, pois acredita que não estão inseridos na realidade do aluno. (PC47)

Contrariamente ao depoimento anterior, houve um professor coordenador que enfatizou justamente o fato do resultado revelar a realidade da escola. Esse mesmo professor coordenador foi o único que fez menção ao uso pela escola dos dados dos questionários respondidos pelos alunos, ressaltando a importância de se conhecer o contexto para compreender melhor os resultados, assim se expressando:

Primeiro passo: com os gráficos mostrados no planejamento, passando a realidade da escola para que os professores tenham ciência das adequações no seu planejamento anual. Segundo: em seguida analisar as habilidades mínimas necessárias e o questionário sócio-econômico, sendo importante, pois lá eles expressam o que esperam da escola onde estudam. (PC27)

Outro relato revela resistência dos professores em relação ao SARESP, mas nada de modo muito incisivo:

Sim, porém existe por parte de alguns professores um pouco de resistência. No início do ano ou no meio (planejamento/replanejamento). Os dados são apresentados pela coordenação (noturno/diurno), depois, por área, discutidos os pontos que podemos melhorar e auxiliar os nossos alunos. (PC4)

Foi feita uma crítica pelo PC29 sobre a dificuldade no uso dos resultados em função da demora na divulgação dos mesmos. Realmente, o acesso aos dados, em algumas aplicações do SARESP, demorou muito. Entretanto nas últimas aplicações do SARESP os resultados foram disponibilizados pela Secretaria de Educação com maior agilidade. No início do ano letivo todas as escolas poderiam já estar de posse dos resultados do SARESP, buscando no site os resultados da avaliação. O relatório mais completo e detalhado, geralmente, tem sido enviado posteriormente. Há, também, a possibilidade da própria escola criar meios de apurar os resultados, já que fica ao seu encargo a correção das redações e a permanência do caderno 
de questões nas escolas. Portanto, a dificuldade em utilizar os dados do SARESP em função do atraso na divulgação dos resultados, precisa ser analisada com maior cautela:

Na medida do possível tem sido utilizado. Apesar de que, às vezes, ficamos sabendo do resultado um pouco tarde, depois do planejamento. Muitas vezes vem resumido e a equipe gestora não tem tempo hábil para fazer uma análise cuidadosa, não conseguindo passar de maneira enfática para que se resolvam os problemas. (PC29).

Apenas um professor coordenador admitiu não fazer uso dos dados do SARESP, mas assume a responsabilidade, alegando a falta de planejamento por parte da equipe gestora:

Não, os dados são informados, geralmente, no planejamento, porém não são traçadas ações efetivas para aplicação nos planos de ensino ou em projetos. O motivo da não utilização, creio, é a falta de um planejamento prévio da equipe gestora. (PC41)

Por fim, citamos apenas que os professores coordenadores 17, 18 e 28 não responderam as questões sobre o SARESP, com o argumento de estar há pouco tempo nessas escolas e não puderam identificar, ainda, informações a respeito do seu uso. Porém, supomos que se os dados do SARESP fossem utilizados com alguma relevância por essas escolas, os professores coordenadores, mesmo há pouco tempo na coordenação, saberiam responder qual o uso do SARESP.

O item b da segunda questão solicitava aos professores coordenadores registrarem eventuais mudanças promovidas na escola, a partir dos resultados do SARESP, bem como o relato do que vem ocorrendo.

Algumas mudanças foram apontadas pelos professores coordenadores nos planos de ensino, na metodologia de trabalho adotada, na recuperação da aprendizagem, na adoção de simulados ou de provas unificadas nos moldes do SARESP. A partir dos resultados do SARESP, segundo os professores coordenadores, também ocorreram mudanças em relação aos conteúdos trabalhados, pois de acordo com as dificuldades dos alunos foram introduzidos conteúdos que antes não eram trabalhados:

Mudamos os planos de ensino, metodologia de trabalho, recuperação de aprendizagem, sempre com o objetivo de melhorar a qualidade do ensino. (PC1)

Passamos a adotar um tipo de prova unificada para podermos comparar, a cada bimestre, como está a aprendizagem dos alunos. (PC2)

Os professores passaram a inserir no plano de aula, nos conteúdos programáticos, ações que abordam o cotidiano do aluno. ( PC3) 
Alguns professores estão desenvolvendo seus trabalhos procurando atingir de forma ampla todas as necessidades do aluno para que este possa progredir. (PC6)

Utilizando os manuais anteriores, utilizando no seu dia-a-dia e no HTPC para novas discussões. No planejamento conversamos muito sobre os resultados. (PC13)

Montamos simulados com referência a esses dados. (PC5)

A preocupação dos professores com relação à questão da leitura e do desenvolvimento da competência leitora deu-se, em boa medida, graças às influências do SARESP, segundo opinião do PC4: "no que diz respeito à leitura, ela não deixou de ser um problema só do professor de língua portuguesa, mesmo tendo alguns colegas que não conseguem entender isso".

O PC7 relatou a participação dos pais no planejamento. É neste momento que os pais tomam conhecimento do desempenho da escola e dos alunos. Essa participação dos pais no planejamento favorece o entendimento deles e dos alunos acerca dos resultados do SARESP. Além do SARESP, outras avaliações externas, como a Prova Brasil, têm sido alvo da preocupação dos professores que procuram orientar os alunos para a realização dessas avaliações. Essas preocupações se evidenciam nos depoimentos a seguir:

Os pais que participam do planejamento verificam os resultados e a transparência e com isso participam mais da rotina da escola. Alguns alunos melhoraram e viram que o SARESP mostra o que ele tem que aprender e cobrar do professor. (PC7)

No encerramento de cada bimestre fazemos uma avaliação interna, buscando sanar as dificuldades apresentados nas avaliações anteriores, trabalhando muito com leitura e interpretação. No momento os professores de Português e Matemática estão fazendo um trabalho de reforço nessas disciplinas no terceiro HTPC, preparando-os para a Prova Brasil e SARESP. (PC9)

Várias mudanças de postura do professor (plano de aula), análise crítica do que foi trabalhado e o que precisa ser evidenciado. (PC10)

Os relatos dos professores coordenadores indicam que do SARESP derivou uma "avaliação unificada e, em cima destes resultados, fazemos levantamento das atividades apresentadas e os professores resgatam suas dificuldades”. (PC11) O SARESP também foi responsável, de acordo com o PC12, por uma melhoria na postura dos professores em relação ao trabalho pedagógico: "observamos professores mais conscientes e levando a sério a sua postura como profissional”. 
Os relatos também evidenciaram o uso dos resultados do SARESP na definição dos alunos que farão parte do grupo em recuperação. Evidenciamos que a avaliação externa vem servindo até para definir encaminhamentos que deveriam ter como referência os dados das avaliações internas, como a decisão de quem deve participar de turmas específicas de recuperação. Essa questão foi apontada pelo PC14: “os resultados foram preponderantes para estabelecer critérios para a formação de turmas de recuperação de aprendizagem”.

Também foi indicado pelos professores coordenadores o uso de materiais do SARESP na sala de aula, reproduzindo o seu modelo para a realização de avaliações similares. Isso demonstra que o SARESP tem influência sobre o trabalho na sala de aula, inclusive na avaliação, pois, devido a ele, a escola introduziu as provas com questões fechadas e alternativas de resposta, já que os alunos demonstraram dificuldade com esse tipo de questão, como ilustram os depoimentos:

Os cadernos do SARESP são utilizados pelos professores em sala de aula, para a melhoria da qualidade e aproveitamento de resultados das aprendizagens significativas dos alunos. (PC15)

Percebemos que um dos problemas é trabalhar com alternativas, por este motivo muitos professores mudaram a forma de elaboração das avaliações e trabalham mais a leitura/interpretação. (PC21)

O SARESP também se reflete nos conteúdos e habilidades na sala de aula, definindo ou redefinindo, de alguma maneira, o currículo escolar. Como relata um professor coordenador, a partir dos resultados são identificadas as dificuldades dos alunos e construídos projetos pedagógicos que visam saná-las. Outras manifestações acerca dessa situação são descritas a seguir:

Optamos por formas de avaliações diversificadas, em algumas séries priorizamos a leitura, em outras as operações matemáticas e, a partir daí, nasceram os projetos pedagógicos. (PC16)

Nas aulas de Língua Portuguesa o trabalho com alguns gêneros que não eram trabalhados tais como: propaganda/publicidade/cartaz/história em quadrinhos/gráficos/gênero científico/jornalístico, pois notamos que a maioria dos nossos alunos errava as questões relacionadas a esses gêneros citados acima, mas principalmente pela necessidade de desenvolver/reforçar nos alunos as competências leitoras. (PC20)

A partir do resultado do SARESP sentimos a necessidade de um trabalho mais direcionado à Matemática. Elaboramos projetos voltados para esta área, começamos a utilizar materiais como sólidos geométricos, ábaco no trabalho em sala de aula. (PC23) 
Uma das principais ações decorrentes dos resultados do SARESP é a avaliação estruturada pela escola e pensada a partir da avaliação externa, como revelam os seguintes relatos:

Aplicando provas semelhantes para que o aluno possa ter o hábito de ter uma prova como a do SARESP, além de promover projetos. (PC31)

Adotou-se uma prova, avaliação interna para todos os alunos e os professores verificarem o desempenho do grupo. (PC34)

Aulas diferenciadas, provão interno e leituras diversificadas. (PC22)

O PC25 registrou que na escola que coordena existem avanços no uso dos resultados do SARESP, mas ainda existe resistência dos professores em relação às habilidades e competências trabalhadas. Segundo ele "[...] os planos de ensino são elaborados a partir das dificuldades encontradas pelos nossos alunos no SARESP. Porém, acredito que ainda falte um maior envolvimento de todas as disciplinas, pois muitos professores ainda defendem a idéia de que as competências de leitura e escrita devem ser exclusivamente trabalhadas pelos professores de Português".

O PC35 menciona mudanças no projeto político pedagógico da escola e que informa os dados do SARESP são utilizados na montagem de projetos que são feitos com o apoio dos professores eventuais da escola: "mudança no planejamento anual, no Projeto Político Pedagógico da escola e o trabalho dos professores eventuais na escola, bem como o interesse dos alunos, professores, pais e comunidade".

O PC39 relatou que o conhecimento dos dados do SARESP faz com que os professores se empenhem, se sintam estimulados a desenvolver o seu trabalho. Enquanto a progressão continuada desestimula os professores, no relato do PC39 parece que ocorre o inverso com o SARESP. Outros professores coordenadores também relataram situações de maior compromisso dos professores com a aprendizagem, a partir do uso dos resultados do SARESP, como segue:

Os professores, já sabendo quais as dificuldades que devem ser mais trabalhadas, se empenham mais na realização de atividades direcionadas a sanar tais dificuldades, melhorando assim a aprendizagem dos alunos. (PC39)

Observamos maior empenho dos professores na utilização de questões do SARESP em sala de aula, já que disponibilizamos os modelos para que sejam trabalhados com os alunos. (PC40) 
Viabilizou uma melhora no comportamento do aluno para a realização das avaliações, os planos de ensino são mais elaborados, concisos e reais, preocupação em alcançar as metas de aprendizagem para o ano letivo, comparar resultados, propor a busca de soluções para os objetivos não alcançados e o professor tem direcionado melhor suas aulas. (PC45)

Apenas o PC48 fez menção ao uso dos critérios de correção das redações como uma mudança na rede, pois os professores estariam adotando essa forma de corrigir os textos dos alunos: "Principalmente nas redações, pois os critérios para correção, não eram os utilizados pelos nossos professores". (PC48)

Pelas respostas dadas pelos professores coordenadores é possível supor que o SARESP tem promovido alterações no trabalho pedagógico, orientando a elaboração de planos de ensino e interferindo diretamente no trabalho em sala de aula. Os relatos que se seguem reiteram alterações induzidas pelo SARESP:

A escola utiliza os dados do SARESP. É feito a análise no planejamento, discutido entre os professores em grupos e depois é feita uma apresentação geral a toda a equipe. Com os dados obtidos, os professores utilizam para elaboração dos planos de curso. Alguns professores usam e aplicam os exercícios do SARESP durante o desenvolvimento das aulas. (PC51)

Os resultados do SARESP sempre geram uma nova visão no enfoque da sala de aula, Aqui nesta U.E. o trabalho dos professores direcionou-se para a leitura de imagens diversas e interpretações matemáticas com conceitos geométricos, além dos reforços [...] com portadores de textos, de modo à oferecer aos alunos a maior diversidade possível.(PC52)

Reflexões, encontros e trocas de atividades entre os professores em HTPC, uso de informática para desenvolver as habilidades de leitura e escrita, entre outros. (PC54)

As mudanças vêm sendo desenvolvidas a cada ano. Baseados nos resultados do SARESP, que tem uma visão externa da escola, elaboraram nossos objetivos, estabelecendo metas para cada série e, a partir daí, conteúdos e estratégias que serão desenvolvidas no plano de ensino e no plano de aula durante o ano letivo, retomados sempre que necessário. (PC55)

$\mathrm{O}$ item $\mathrm{b}$ da questão 2 evidencia que os resultados do SARESP têm influenciado sobremaneira o trabalho escolar. Ao que parece, conta com o apoio dos professores, pois foram poucos os relatos que indicaram haver resistência. Pelo que foi exposto pelos professores coordenadores, parece que há uma maior aceitação do SARESP do que da progressão continuada.

A terceira questão que faz parte do questionário aplicado aos professores coordenadores era a seguinte: você identifica diferença entre os resultados obtidos pelos alunos na avaliação feita pelo professor e os obtidos no SARESP? O objetivo desta questão é 
coletar possíveis evidências de relações entre essas duas formas de avaliar no interior da escola.

Dos 57 professores coordenadores que responderam as questões, 17 disseram que não identificam discrepâncias entre os resultados de ambas as avaliações, enquanto que 40 professores coordenadores disseram identificar alguma discrepância. Entre os que identificaram alguma discrepância entre os resultados da avaliação da aprendizagem e da avaliação externa, metade diz que essa discrepância vem diminuindo com o tempo.

Segundo os professores coordenadores a falta de compromisso dos alunos no momento de realizarem a prova do SARESP (a pressa em terminar a prova) se configura em um dos principais problemas. Há referência a necessidade de se conscientizar os alunos para que tenham responsabilidade no momento da realização da prova, o que consideram de fundamental importância para a melhoria dos resultados do SARESP:

O problema maior que costumamos observar é a falta de comprometimento do aluno. Ele parece que não lê os textos, tem muita pressa para terminar e acaba respondendo qualquer coisa. Isso é o que a maioria dos professores reclama. Também tem professores que trabalham nos moldes do SARESP. (PC9)

Muitos alunos bons se deixam levar pelo nervosismo na hora da avaliação do SARESP e obtém resultados ruins. (PC24)

Normalmente o professor não tinha o hábito de aplicar provas como a do SARESP, porém com a aplicação de provas semelhantes, essas discrepâncias diminuíram, porém ainda existem alguns casos. (PC31)

O aluno ainda precisa ser conscientizado da importância da prova SARESP. (PC35)

Um aspecto explicitado pelos professores coordenadores em relação às avaliações feitas no interior das escolas pelos professores e a avaliação externa é a natureza de cada uma delas, pois se utilizam de procedimentos avaliativos diferentes. Enquanto uma procura utilizar vários instrumentos e de momentos de avaliação diferenciados, a outra se caracteriza como uma prova teste aplicada num momento pontual. Essas avaliações também apresentam, muitas vezes, diferenças no que se avalia, como e para que se avalia, o que podem provocar resultados diferentes nas avaliações. Os depoimentos a seguir retratam essas diferenças:

A avaliação feita pelo professor implica além da aprendizagem de conteúdos e conceitos, aspectos relacionais e atitudinais. (PC14)

O professor avalia o aluno continuamente respeitando o seu avanço crescente e sua mudança de comportamento. Enquanto no SARESP o aluno 
é avaliado individualmente não respeitando essa evolução e muitas vezes mostrando uma aprendizagem falsa e classificatória. (PC37)

Dessa forma, se ocorrerem discrepâncias entre os resultados, podemos encontrar diferentes explicações:

Percebo que no SARESP é cobrado muitas vezes o conteúdo e habilidades que com a progressão continuada são trabalhados, mas os alunos não possuem o compromisso na realização do SARESP, pois dizem que não reprova. $(\mathrm{PC} 1)$

$\mathrm{Na}$ avaliação contínua o professor enxerga o aluno de forma global e analisando o seu desenvolvimento passo a passo, respeitando o ritmo de cada aluno e a realidade de nossa comunidade. O SARESP trouxe um resultado baixo porque a prova desconsidera o aluno como um todo e o processo de aprendizagem, uma forma de nivelar todos. Favorece assim a exclusão e a forma classificatória. (PC2)

Acredito que a situação de avaliação e a linguagem utilizada muitas vezes dificultam o desempenho do aluno, principalmente dos alunos que, mesmo competentes, encontram dificuldades na linguagem escrita e/ou na leitura. (PC6)

Algumas respostas que foram dadas responsabilizam as discrepâncias nos resultados das avaliações a falta de compromisso dos alunos quando respondem ao teste ou ao descaso do professor que não procura trabalhar de acordo com a proposta da escola, preparando os alunos para o SARESP, como já evidenciado anteriormente. Alguns depoimentos reforçam essa situação:

Alguns professores ainda não trabalham de acordo com a proposta pedagógica da escola, mesmo sendo discutida em reuniões de planejamento, replanejamento e HTPC. Isto leva a um trabalho individual e onde não se alcança os objetivos propostos, levando assim a discrepância na avaliação. (PC23)

Percebo que muitos alunos parecem não dar a devida importância para esta avaliação, desta forma não lêem os textos e questões do SARESP cuidadosamente. Além disso, acredito que, muitas vezes, a avaliação feita pelo professor seja sempre com os mesmos critérios, desta forma os alunos habituam, isto é, acabam desenvolvendo em todas as avaliações do professor sempre as mesmas habilidades ao passo que no SARESP são várias as habilidades contempladas. (PC25)

Ainda há falta de compromisso do aluno na hora da prova; também há alunos que não conseguem realizar a prova por nervosismo. Mas, os professores estão conversando com os alunos, há uma conscientização da importância da avaliação. (PC51)

Alguns poucos professores coordenadores relataram que o fato das avaliações terem características muito peculiares possibilita que se chegue a resultados diferentes entre elas. 
Além disso, comentam que os professores deveriam preparar os alunos para a avaliação, pois não estão acostumados com a avaliação que se utiliza de testes:

Ocorrem muitas discrepâncias devido ao tipo de avaliação em sala de aula, as questões de alternativas nos moldes do SARESP são trabalhadas com pouca freqüência, até o professor passar um texto na lousa, passar as questões... Os alunos já colaram, é caro reproduzir provas e fazer um bom trabalho. (PC47)

$\mathrm{Na}$ avaliação interna, feita pelo professor, o aluno, muitas vezes, se sente seguro em realizar esta avaliação e o professor tem um olhar mais completo, pois este fez o acompanhamento de todo processo de aprendizagem de seu aluno. Por outro lado, os alunos que têm segurança do seu conhecimento no que aprenderam, já têm autonomia para realizar a avaliação. (PC55)

Dos 17 professores coordenadores que disseram não haver discrepância, apenas um procurou esclarecer o motivo de sua resposta. Segundo ele o resultado é previsível e o importante é valorizar o trabalho cotidiano na escola: "Geralmente o resultado já é previsível. O trabalho na sala de aula é fundamental para que o aluno consiga fazer a avaliação de forma clara e objetiva”. (PC10)

Percebemos que as relações que os professores coordenadores estabeleceram entre a avaliação feita no interior da escola, aprendizagem, com a avaliação do desempenho recaem, mais uma vez, sobre o comprometimento do aluno e/ou envolvimento do professor. Os professores coordenadores não fizeram críticas ao SARESP, apenas deixaram implícito não serem contrários a essa política.

A partir das respostas dadas no questionário procuramos levantar alguns pontos para aprofundamento na realização das entrevistas. Um aspecto que procuramos explorar nas entrevistas foi de como se processa a avaliação da aprendizagem, como ela é entendida e praticada pelos professores. Quanto aos usos dos resultados do SARESP procuramos compreender como são utilizados, que ações são desenvolvidas pelos professores a partir desses resultados. Também exploramos nas entrevistas as relações que se estabelecem entre a avaliação da aprendizagem e a avaliação do desempenho, pois não foi possível perceber pelas respostas dadas no questionário. 


\subsection{Depoimentos relatados em entrevistas}

Neste item apresentaremos a descrição e análise dos dados coletados nas entrevistas realizadas com os professores coordenadores.

As opiniões foram coletadas por meio de entrevistas (ver Anexo II) realizadas com onze professores coordenadores durante o ano de 2008. Os entrevistados foram escolhidos levando em consideração terem respondido ao questionário e terem atuado até 2007 como professores coordenadores de escolas que atendiam ao Ciclo I e ao Ciclo II, pois é o Ensino Fundamental que adota o regime de progressão continuada. Além disso, o grupo de entrevistados deveria contemplar professores coordenadores que atuam em escolas exclusivas de Ciclo I, professores coordenadores de Ciclo II e professores que não retornaram para a coordenação em 2008.

O objetivo de entrevistar professores coordenadores que trabalham com escolas que atendem somente o Ciclo I e ou o Ciclo II deve-se as especificidades que envolvem cada segmento, particularmente no que se refere ao trabalho pedagógico. Enquanto nos anos iniciais do Ensino Fundamental tem-se um professor responsável por um grupo de alunos, nas séries finais conta-se com professores especialistas que atendem a diferentes séries, atuando, por vezes, em mais de uma escola.

Importante retomarmos algumas informações já apresentadas no capítulo anterior acerca de mudanças que se processaram na função de professor coordenador no final de 2007.

Por conta dessa mudança todos os professores coordenadores que atuavam em escolas que atendiam Ciclo II e Ensino Médio tiveram suas designações cessadas no início do ano letivo de 2008. Foi realizado no mês de março um novo concurso para credenciamento dos docentes que concorreriam a ocupar a função de professor coordenador. Os credenciados, após processo seletivo realizado em cada unidade escolar, foram designados a partir de abril. A exceção foram os professores coordenadores que atuavam em escolas de Ciclo I, pois estes não foram cessados no início do ano letivo, mas passaram por processo de credenciamento e seleção, ocorrendo à mudança de designação no final de junho e começo de julho de 2008.

Vale frisar que quatro mudanças proporcionadas pela alteração na legislação favoreceram o desenvolvimento da função: 
- Designação do professor coordenador para cada segmento de ensino: Ciclo I, Ciclo II e Ensino Médio. Anteriormente a designação era feita por turno, diurno ou noturno, o que, em muitos casos, fazia com o os coordenadores do diurno atuassem com dois ou até três segmentos, dificultando seu trabalho.

- Dependendo da quantidade de turmas que o segmento possui pode ser designado mais de um professor coordenador para o mesmo segmento, possibilitando uma melhoria nas condições de trabalho.

- A legislação, ao explicitar o professor coordenador como implementador da política, promoveu uma gratificação para a função, o que não existia até 2007.

- Devido à importância dada pela Secretaria de Educação ao papel do professor coordenador houve, a partir de 2008, a publicação de orientações para sua atuação cotidiana no chamado Caderno do Gestor.

Em relação a essas mudanças, apesar de serem recentes e considerando as opiniões manifestadas durante as entrevistas, alguns dos entrevistados afirmaram que elas explicitaram o papel do coordenador e tornaram melhores as condições de desenvolvimento do seu trabalho:

Realmente é estar auxiliando o professor em sala, o professor na capacitação, nessa nova formação, bem claro o papel do professor coordenador. É claro que nós continuamos a ser mediadores entre direção e professores, direção e comunidade, professores e comunidade. Mas é muito importante, ficou bem clara na proposta do governo essa formação, o papel que o coordenador exerce nessa formação do professor. (PCII) (grifos meus)

O problema é que a função do professor coordenador não era bem clara. $\mathrm{O}$ papel do professor coordenador hoje na escola está ligado realmente ao pedagógico. Temos uma proposta e essa proposta já traz bem claro a função do professor coordenador. Até então o coordenador só passava recado, tinha coordenador que fazia serviço de secretaria e essa não é a função. Coordenador tem que cuidar do pedagógico. (PCIX) (grifos meus)

Entretanto, também houve manifestação de insatisfação quanto à maneira como a mudança estava se processando, afirmando um dos entrevistados:

Acho que é válida essa mudança, mas não acho que só isso basta. O novo plano que a Secretaria está desenvolvendo, esse caderno, acho que vem auxiliar, é um caminho que você tem e fica mais fácil acompanhar e auxiliar o professor. Pego os cadernos, olho, quando vou conversar com o professor discuto porque ele está trabalhando daquele jeito. Caderno do gestor ${ }^{21}$

${ }^{21} \mathrm{O}$ caderno do gestor a que o entrevistado faz referência foi elaborado pela Secretaria de Educação com o objetivo de orientar os professores coordenadores na implantação da nova proposta curricular que se processou 
precisaria ser melhor discutido. A equipe gestora da escola falha em não sentar para discutir. Também teria que haver um acompanhamento. Tem uma orientação assim, básica. O caderno do gestor tem isso e isso, precisa fazer isso. Só que eu não vejo respostas, fica uma coisa perdida. (PCV)

Com o objetivo de sistematizar algumas informações sobre os entrevistados esboçamos um perfil do grupo, apresentado na tabela 3:

Tabela 3 - Dados gerais dos professores coordenadores entrevistados

\begin{tabular}{|c|c|c|c|}
\hline PC & $\begin{array}{c}\text { Segmento em } \\
\text { que atua em } \\
\mathbf{2 0 0 8}\end{array}$ & Formação & $\begin{array}{c}\text { Tempo na coordenação } \\
\text { até 2007 }\end{array}$ \\
\hline I & Ciclo I & PEB I $^{22}$ & 04 anos \\
\hline II & Ciclo II & PEB II - Língua Portuguesa & 04 anos \\
\hline III & Não & PEB II - Arte & 11 anos \\
\hline IV & Ciclo I & $\begin{array}{c}\text { PEB I, PEB II - Ciências, } \\
\text { Biologia e Matemática. }\end{array}$ & 08 anos \\
\hline V & Ciclo II & PEB II & 08 anos \\
\hline VI & Deixou a função* & PEB II - Língua Portuguesa & 03 anos \\
\hline VII & Deixou a função & PEB I & 2,5 anos \\
\hline VIII & Deixou a função & PEB II - Ciências e Biologia & 03 anos \\
\hline IX & Ensino Médio & PEB II - Língua Portuguesa & 05 anos \\
\hline X & Ciclo I & PEB I e PEB II - Educação & 14 anos \\
\hline XI & Ciclo II & Física & 05 anos \\
\hline
\end{tabular}

(*) Professor atuou como coordenador até 2007 e não foi designado para a coordenação em 2008.

Para melhor compreensão dos dados apresentados na tabela, é importante que se façam alguns esclarecimentos, pois dos 11 entrevistados, quatro não retornaram para atuar como professores coordenadores em 2008. Dos quatro, apenas a PCVI não retornou por optar atuar como vice-diretora, as outras três participaram do credenciamento e da seleção nas mesmas

no ano de 2008 e se consolida em 2009. Esse caderno serve para orientar o trabalho do professor coordenador em relação ao planejamento escolar e a avaliação escolar.

Como o recorte deste estudo é a atuação do professor coordenador até 2007, não entraremos no mérito da mudança. Consideramos, entretanto, a importância de alertar a necessidade de estudos que acompanhem esse processo, na medida em que a própria Secretaria de Educação anuncia sua relevância para a implementação da política educacional, que tem, entre outros, foco na mudança curricular e na consolidação do SARESP como meios de promoção da melhoria do ensino.

${ }^{22}$ PEB I significa Professor de Educação Básica I, são professores que lecionam no Ciclo I, $1^{\mathrm{a}}$ a $4^{\mathrm{a}}$ série; e PEB II significa Professor de Educação Básica II, são professores especialistas em uma disciplina e que atuam no Ciclo II ( $5^{\mathrm{a}}$ a $8^{\mathrm{a}}$ série $)$ e Ensino Médio.

${ }^{23}$ Este entrevistado, em 2008, passou a coordenar exclusivamente o Ensino Médio, mas até o ano de 2007 atuava como coordenador de Ciclo II e Ensino Médio. 
escolas em que atuavam, mas não foram aceitas para continuar na função. Quando perguntado o motivo de não terem sido aceitas, um dos motivos explicitados foi à mudança da legislação que tirou do Conselho de Escola o processo seletivo de escolha do professor coordenador, atribuindo essa tarefa ao diretor e supervisores de ensino. As impressões dessas entrevistadas denotam essa situação:

Nessa nova legislação do coordenador, que eu discordei, é a questão do diretor e supervisores escolherem o coordenador. Muita gente boa ficou de fora. Tinha uma gama de coordenadores excelentes, que estavam desenvolvendo trabalhos maravilhosos na escola. Aqui mesmo tinha uma coordenadora $^{24}$ maravilhosa e, por uma questão de legislação, não pode ficar. Era uma coordenadora que na Diretoria de Ensino era muito bem vista, mas a própria legislação podou, tirou isso dela. No caso de outras escolas também. A escolha foi feita considerando quem eu gosto ou porque esse é meu amigo. Agora coordenador virou uma função de confiança do diretor. Não é mais o Conselho que escolhe quem é mais adequado pra escola. Não, é o que é adequado para o diretor. Pouquíssimos diretores estão tendo a visão de que o coordenador tem que estar bem com professores, comunidade e, principalmente, com os alunos. E assim, por essa nova legislação o coordenador sempre tem que estar de bem com a direção, não é por aí. (PCVII)

Estou inconformada com essa situação. Fiquei três anos na coordenação e não apresentei proposta em nenhuma outra escola, tinha certeza que iria continuar lá. Fiz a proposta e fui para a entrevista, acho que me saí bem. Falei para a supervisora que meu trabalho de três anos não dá para ser medido, é um trabalho a longo prazo. Quando saiu o resultado disseram num primeiro momento que não fui escolhida por não ser efetiva. Não me explicaram e ficou um disse me disse na escola. Sair da coordenação, tudo bem, mas tinha o direito de saber onde foi que eu errei. Com o passar do tempo, como continuei na escola, começaram as provocações, que a escola estava no grupo das piores da diretoria de ensino. $\mathrm{O}$ ano de 2007 foi muito difícil de trabalhar, houve a reforma, a mudança da direção, o noturno se rebelou pelo enfrentamento entre a diretora e a funcionária que tinha $\mathrm{o}$ controle do noturno, boicotaram o SARESP. A diretora escolheu um professor novo na escola, efetivo que veio na remoção. (PCVIII)

Concordamos que não permitir que o Conselho de Escola participe da escolha do professor coordenador faz com que esse processo seja menos democrático, ficando a responsabilidade nas mãos do diretor e dos supervisores de ensino. Não questionamos com isso a competência ou a lisura dos diretores e supervisores na escolha e manutenção do professor coordenador, mas sim o fato da decisão ficar restrita somente a esses profissionais,

\footnotetext{
${ }^{24}$ Interessante dizer que a professora coordenadora que a entrevistada faz menção é a entrevistada 03.
} 
não possibilitando a participação dos representantes de docentes, discentes, pais e funcionários.

Vale lembrar que, anteriormente, quando a escolha e permanência do professor coordenador eram decididas pelo Conselho de Escola, também existiam problemas, como relatado por este entrevistado:

Até o ano passado o problema é que a função do professor coordenador não
era bem clara. Porque, até então, como era o grupo de professores que
colocava o coordenador na escola, eles achavam que mandavam e o
coordenador fazia. Você ficava a mercê do grupo de professores, querendo
ou não você era eleito pelo Conselho. De um modo ou de outro eram os
professores que te colocavam na função. Com a nova proposta, percebi que
essa visão já mudou. Que o papel do professor coordenador hoje está ligado
realmente ao pedagógico. (PCIX)

Para concluir essas observações acerca dos professores coordenadores que não retornaram para a coordenação em 2008, informamos que das três que passaram pelo processo seletivo e não retornaram, na época em que foram entrevistadas, duas permaneciam em sala de aula, PCIII e PCVIII, e a PCVII estava designada como diretora de escola.

A partir do entendimento que os entrevistados manifestaram acerca da função do professor coordenador identificamos seis características que foram mais enfatizadas. A tarefa de orientar os professores, alunos e as famílias foi a mais citada, mencionada a orientação específica aos professores por cinco entrevistados, enquanto que a orientação aos alunos e as famílias foi atividade a que dois professores fizeram referência. $\mathrm{O}$ acompanhamento do trabalho pedagógico pelo professor coordenador foi mencionado por cinco entrevistados, enquanto que os papéis de mediador na escola entre os diferentes grupos (alunos, professores, direção, famílias, funcionários) e de formador dos professores foram, explicitamente, indicados por quatro entrevistados. A necessidade de realizar tarefas burocráticas, tais como preenchimento de registros, relatórios, fichas de encaminhamento, foi mencionada por dois entrevistados, além disso, um entrevistado fez menção à necessidade de manter os professores informados das "novidades" pedagógicas e da legislação.

Se considerarmos as ações explicitadas de orientação, acompanhamento, mediação, informação e formação, podemos afirmar que os entrevistados anunciaram, em boa medida, o papel apregoado pela legislação que define a função do professor coordenador na escola.

Por outro lado, o que foi explicitado na fala dos entrevistados, também manifesta o que eles consideram mais importante na sua atuação e essa importância vincula-se, ao menos 
em parte, ao que o contexto em que trabalham deles exige. Sendo assim, os entrevistados que mencionaram a orientação aos pais e alunos, enfatizando esse papel, convivem em contextos em que essa tarefa se faz mais premente, como ilustram estas falas:

Meu objetivo principal era resgatar aqueles alunos que estavam esquecidos, não participavam de nada, não sabiam o que acontecia na diretoria de ensino. Minha preocupação foi de motivá-los a participar das atividades, resgatar a comunidade e mostrar o seu valor. Depois que comecei a trabalhar com a comunidade e com os alunos, comecei a envolver os professores e os funcionários. (PCVIII)

A parte pedagógica é muito importante, mas a parte de você lidar com os pais, com os alunos, aconselhar os pais em como orientar os filhos nos estudos em casa, alguns até não sabem como tratá-los. (PCIII)

O que se evidencia nas opiniões sobre a função do professor coordenador é seu papel de formador do grupo de professores. Essa ênfase, como já mencionado, está presente na legislação mais recente que caracteriza o papel do professor coordenador:

II - atuar no sentido de tornar as ações de coordenação pedagógica espaço coletivo de construção permanente da prática docente;

III - assumir o trabalho de formação continuada, a partir do diagnóstico dos saberes dos professores para garantir situações de estudo e de reflexão sobre a prática pedagógica, estimulando os professores a investirem em seu desenvolvimento profissional. (Artigo $2^{\circ}$, Resolução SE nº 88/07)

O papel do professor coordenador na formação, na orientação, no acompanhamento do trabalho pedagógico, além de ser definido legalmente, também encontra respaldo em estudos que se dedicaram a refletir sobre a função desse profissional no trabalho escolar. Segundo Vasconcellos:

O coordenador, ao mesmo tempo em que acolhe e engendra, deve ser questionador, desequilibrador, provocador, animando e disponibilizando subsídios que permitam o crescimento do grupo; tem, portanto, um papel importante na formação dos educadores [...]. (2008, p. 89).

Quatro das entrevistadas destacaram a importância da atuação do professor coordenador na formação dos professores:

Orientar os professores, alunos, sanar algumas dificuldades que elas têm. [...] Sempre tem uma coisa diferente, a maior parte do trabalho é de orientação mesmo, acompanhamento, divulgar as coisas novas que estão surgindo. (PCI)

Acho que basicamente é acompanhar o desenvolvimento das crianças, estar perto do professor, articular as coisas dentro da escola com o grupo de professores e a direção, fazer um elo entre eles. O foco principal mesmo para mim é isso, ajudar o professor na prática dele em sala de aula. (PCIV) 
A função do coordenador pedagógico é preparar os professores para enfrentar a sala de aula, para o trabalho na sala de aula, desenvolvendo estratégias, técnicas para sanar as dificuldades dos alunos, fazendo realmente o pedagógico da escola. (PCV)

O professor coordenador está sempre estudando para ter uma visão ampliada da melhoria do ensino. Procurava fazer a formação continuada deles da melhor maneira que eu sabia. (PCVI)

A PCIV ainda evidenciou ser a formação dos professores o foco principal da sua prática:

A questão da formação eu procuro garantir nas reuniões de HTPC. Divido as pautas em estudo, planejamento de atividades, de aula juntamente com os professores, baseado no estudo que nós fizemos e de acompanhamento. $\mathrm{O}$ foco principal no HTPC é a formação. No cotidiano da escola acompanho a rotina delas em sala de aula e faço um trabalho de sondagem com os alunos, principalmente com os da $1^{\text {a }}$ série, procurando acompanhar de perto o avanço que eles apresentam. Com esse acompanhamento eu consigo observar e ter um retorno daquilo que a gente combina e trabalha no HTPC.

Ao ser indagada sobre como desenvolveu essa forma de organizar seu trabalho com os professores, ela esclareceu que aprendeu com uma coordenadora que teve na escola, além do apoio e orientação da diretora. Também revelou que as orientações da Diretoria de Ensino e sua participação como formadora no curso Letra e Vida contribuíram na organização da sua ação com os docentes, além de fazer cursos de especialização voltados para a temática da alfabetização:

No começo fui fazendo pela minha prática, pois tive uma experiência quando estava na sala de aula com a minha coordenadora. Depois fui recebendo as orientações da diretoria de ensino, nós tínhamos capacitação do que estar trabalhando com o professor e fui pesquisando outras coisas também, trabalhei no grupo do Letra e Vida como formadora, isso me ajudou bastante a ter embasamento para focar a formação no HTPC. Eu sou PEB I e PEB II, fiz o magistério, depois fiz Biologia, Matemática e Pedagogia para trabalhar com $1^{\mathrm{a}}$ a $4^{\mathrm{a}}$ série. Fiz alguns cursos de especialização dentro da alfabetização. Penso e procuro agir dessa forma, se estou trabalhando com um grupo e o foco é alfabetização, então tenho que buscar coisas para atender a esse grupo. (PCIV)

O que importa ressaltar na fala desta professora coordenadora é a coerência que podemos identificar entre o que pensa sobre a função e como procura atuar na prática. Além disso, demonstra uma busca constante de aperfeiçoamento, revelada desde o início de sua docência, e também o reconhecimento da importância de compartilhar experiências que serviram como exemplo. Quando foi perguntado o motivo de ter optado por deixar a sala de aula e atuar na coordenação pedagógica, ela respondeu que: 
Porque eu gosto do trabalho de formação, gosto de conduzir o grupo, de estar ajudando as professoras na prática da sala de aula. Gosto desse trabalho de formação e de acompanhar o desenvolvimento das crianças. Acho que posso ajudar mais, ampliar mais os meus conhecimentos sobre aquilo que vou buscar, não só na sala de aula. (PCIV)

Essas impressões permitem afirmar a importância do perfil do professor coordenador ao assumir a função, os motivos que o levaram a buscar a coordenação pedagógica e também seu interesse em atuar como formador dos professores. Em relação a essa questão, os dados coletados dos entrevistados permitiram identificar que os motivos mais apontados são o desafio e o crescimento profissional; seguidos de "gostar do trabalho da coordenação pedagógica" e "ter vontade"; o fato de já agir como coordenador no grupo de professores; por gostar de lidar com pessoas; ter experiências profissionais de coordenação anteriores.

Essas informações evidenciam que a maioria dos entrevistados apresentou como motivos para deixar a sala de aula e assumir a função de professor coordenador o desafio e crescimento profissional. Das opiniões emitidas, selecionamos as que seguem como ilustrativas:

Buscar uma coisa nova, ver o outro lado (PCI)

Eu acabei aceitando o desafio e iniciei como coordenador. (PCV)

Todos os lugares que eu trabalho, escuto sempre a mesma coisa - você tem que estar do lado de lá, como coordenadora, como vice-diretora, diretora [...] pra você entender melhor e saber tomar atitudes melhores e crescer como ser humano e como indivíduo. (PCVI)

Havia feito uma pós-graduação em administração escolar e coordenação pedagógica e gostei muito do que estudava, da situação que seria vivenciada pelo coordenador e queria me desafiar para novas situações e resolvi aceitar. (PCVIII)

Sair da sala de aula foi um desafio, naquele tempo tudo era novo. O diretor da escola na época perguntou se eu gostaria de ser professora coordenadora e eu aceitei. (PCX)

Na verdade estava meio cansada da rotina de sala de aula. Já tinha mais de dez anos de magistério e minha área não me oferecia muitas opções de avanço. Não tinha cursos para a área de Arte, só ficava na sala de aula e senti que estava ficando para trás, não estava evoluindo. (PCXI)

Apesar de considerarmos que colocar-se diante de desafios e desejar o crescimento profissional são elementos fundamentais para o comprometimento profissional com o trabalho que realiza, parece que gostar daquela função e ter vontade de realizá-la assume um caráter mais relevante, quando se pensa no papel do professor coordenador. Obviamente que, de acordo com o que se espera dessa função, principalmente pelo que está explicitado na 
legislação, atuar como professor coordenador deve representar, também, vontade de trabalhar com a formação dos professores como manifestado pela PCIV:

Porque eu gosto do trabalho de formação, gosto de conduzir o grupo, de estar ajudando as professoras na prática da sala de aula. Gosto desse trabalho de formação e de acompanhar o desenvolvimento das crianças. Acho que posso ajudar mais, ampliar mais os meus conhecimentos sobre aquilo que vou buscar, não só na sala de aula.

É importante para o profissional que decide assumir essa função ter clareza do papel que deverá desempenhar e da capacidade e competência necessárias para o exercício desse trabalho. É essa clareza que possibilita ao profissional mensurar o desafio que terá pela frente; as dificuldades que deverá superar e que são inerentes à função, além daquelas que são específicas da escola ou segmento que coordena.

Nesse sentido, a indagação feita aos entrevistados dizia respeito às dificuldades ou resistências que enfrentam no desempenho da sua função. As dificuldades e resistências elencadas vão desde problemas cotidianos da escola que sobrecarregam o professor coordenador no atendimento a professores, alunos e pais, passando por problemas e falta de funcionários que obrigam os coordenadores a abrir e fechar portões, ajudar na merenda, cuidar de indisciplina, situações que eles designaram como desvio de função. Os depoimentos a seguir são ilustrativos dessa situação:

O que ocorria era que às vezes, não era o meu caso, mas muitos colegas o diretor pedia para atender questões de indisciplina, para abrir o portão. A função do coordenador não era muito definida, o coordenador era uma espécie de bombril. Em alguns momentos aqui na escola, como ainda hoje se for necessário, se não houver ninguém da direção e da vice-direção, se eu estiver mais perto do "incêndio" vou atuar. (PCII)

As orientações que vem para a gente são muito bonitas no papel, mas não são praticadas na escola. Por exemplo, eles falam que eu não posso fugir da minha função, que devo cuidar da parte pedagógica somente. A legislação diz mais ou menos isto. Mas é preciso ver a família, às vezes até abrir o portão é preciso fazer sim.

Quando se coloca no papel qual é a função do professor coordenador, é importante saber o que é de responsabilidade do professor coordenador, mas o que está escrito não é muito praticável não. A parte pedagógica sim está correta. Mas a gente acaba fazendo muitas outras coisas também. Isso faz com que eu tenha menos tempo para me dedicar a parte pedagógica e sou criticada por isso. (PCIII)

Foge ao que foi proposto, ele deveria estar o tempo dentro da escola, da sala de aula, mas não consegue, não porque não queira, porque tudo é atrás dele. É problema com aluno, vai atrás dele, os pais vêm, vão atrás dele. (PCVII) 
Alertaram que há um distanciamento entre o que se espera e anuncia na legislação como sendo a função do professor coordenador e o que, na prática, eles realizam, havendo um fosso entre o legal e o real. Parte desse distanciamento deve-se as condições de trabalho, a desarticulação da equipe gestora, ao excesso de burocracia e as dinâmicas da rede de ensino que promovem mudanças periódicas no corpo docente ou equipe de gestão, devido aos processos de remoção, como ilustram os depoimentos:

A equipe gestora da escola falha em não sentar para discutir. Também teria que haver um acompanhamento. O que me entristece muito é você desenvolver, desenvolver e quando vem são cobranças somente. [...] No estado você não tem uma resposta das ações que você faz. Você envia relatório e fica perdido, não tem uma devolutiva. (PCV)

Quando se atribui ao coordenador que preencha isso, preenche aquilo, registra, registra, vira um serviço burocrático. Infelizmente existe uma cobrança de cima de registro e essa cobrança, de cima para baixo, o coordenador perde muito tempo preenchendo papéis. Se eles tivessem a disponibilidade de o tempo todo estar no corpo a corpo com professor e aluno, envolto em outro tipo de atividade, com a comunidade, acredito que as escolas seriam muito melhores pedagogicamente falando. (PCVII)

Reclamação dos pais, dos professores, esse trabalho ficou todo para mim, porque houve mudança de diretor no meio do ano por causa da remoção. (PCVIII)

O acúmulo dos papéis acaba fazendo com que você cuide só do burocrático, deixando o pedagógico de lado, o que não poderia acontecer. Você tem que trabalhar com o pedagógico. Agora isso não significa dizer que o pedagógico não tenha um lado burocrático, mas um burocrático voltado para as questões pedagógicas, não só para o administrativo. (PCIX)

Como os principais objetivos do trabalho do professor coordenador são orientar e acompanhar o trabalho pedagógico, este profissional deve atuar diretamente ao lado dos professores. Sendo assim, a resistência dos professores, seja em relação às orientações oficiais que ficam ao encargo do professor coordenador implementar na prática pedagógica, quanto às mudanças e transformações que norteiam a educação, as novas teorias e conhecimentos difundidos pela literatura, pelas pesquisas e que, em alguns casos, fundamentam aspectos da política educacional, não deixaram de ser apontados como obstáculos ao trabalho do professor coordenador:

Numa escola, para você dar conta do pedagógico, teria que ficar trancado numa sala o período todo estudando, sentando com o professor. Os horários de HTPC nem sempre são para sanar as dúvidas. Você precisaria ter mais acompanhamento. Acho que falta acompanhamento da oficina pedagógica. Mais acompanhamento de outros locais que possam te auxiliar, porque é difícil chegar e mudar a visão do professor que ele, principalmente os mais antigos. (PCV) 
A dificuldade que eu encontro é devido à falta de comprometimento de alguns professores. (PCIX)

Você tem que trazer o grupo junto com você [...], tem que agir junto com eles, ver as necessidades dos professores. Os problemas que eles enfrentam é seu também. Agora se o grupo não gosta de você complica. (PCX)

Falta de tempo mesmo, falta de tempo para estudar. O estudo, a leitura exige concentração [...]. Tinha um pouco de frustração também pelo que era combinado nos HTPCs. Você combina, faz um acordo, mas chega na sala de aula meia dúzia trabalha e meia dúzia não. Quando você está na coordenação você tem uma visão muito ampla do que acontece, mais do que na sala de aula. Você percebe muito bem o trabalho de cada professor. Às vezes dava um pouco de frustração em ver que havia um grupo de professores falava uma coisa e fazia outra. (PCXI)

A PCIV também indicou como a principal dificuldade que enfrenta na sua atuação como professora coordenadora a resistência dos professores, o interessante é notar que ela faz uma análise dessa situação diferente dos demais entrevistados. Entende essa resistência não como simples não aceitação da política educacional ou desinteresse ou falta de compromisso, mas como medo à inovação, como dificuldades em alterar modelos em relação aos quais está habituado e enfrentar o desafio de mudar a prática. Ela analisa a situação de seu grupo e essa análise torna-se motor para que busque soluções, apóie o professor e dê segurança para que eles se "aventurem" nas mudanças que procura estimular:

Não é resistência, acho que é o medo de inovar, principalmente no ciclo I. Agora nós temos uma proposta de trabalho totalmente diferente daquilo que vem sendo trabalhado no ensino de $1^{\mathrm{a}}$ a $4^{\mathrm{a}}$, na questão do ensino tradicional, sinto que as professoras têm muito medo. Esse medo é um dos pontos que me fez continuar trabalhando com o ciclo I, porque acho que quando cobro alguma coisa do meu professor tenho que dar respaldo para aquilo. É aí que entra essa questão da formação, se elas precisam trabalhar dentro de uma proposta, seja a que o governo coloca ou que a sociedade está pedindo, e não conhecem, não vou ter um bom resultado, não vou poder cobrar nada delas. Meu foco é ensinar, passar as orientações dentro da proposta, dou condições para elas aplicarem na sala e depois darem um retorno. Tenho que estar lado a lado, falo para as professoras que assim como elas têm os alunos que acompanham passo a passo, eu as tenho como minhas alunas também. A dificuldade que enfrento é essa, o medo, a resistência a mudança. (PCIV)

Essa clareza revelada pela entrevistada sobre as resistências das professoras que coordena fica explicitada quando ela nos relata como procura orientá-las e alcançar os objetivos e metas que se estabelecem na escola:

Ao mostrar os resultados, que pode dar certo, oriento o caminho que elas têm que seguir mesmo. O planejamento das aulas, o acompanhamento das avaliações que são feitas com os alunos. Isso tem ajudado muito, senti que elas estão com mais confiança. Você cobra, mas orienta. Isso faz com que eu 
também tenha que buscar, que estudar junto com elas. É uma dificuldade, medo da mudança, mas não impede que realize o meu trabalho. (PCIV)

A postura do coordenador de formador, de orientador, de quem acompanha é descrita pela entrevistada como de parceria, diálogo, acolhimento e não de cobrança e punição. A preocupação com coisas simples como o planejamento das aulas, a organização da rotina escolar, a compreensão dos processos de aprendizagem podem favorecer um melhor relacionamento do professor coordenador com os docentes, diminuindo resistências e estabelecendo um clima de confiança.

A partir dos relatos e opiniões sobre a função do professor coordenador fica evidente a importância desse profissional na condução do trabalho pedagógico e na implementação da política educacional.

As opiniões dos entrevistados permitem concluir que, apesar da mudança realizada de 2007 para 2008, o professor coordenador está vulnerável diante da gama de problemas que afetam a escola. Essa vulnerabilidade se materializa pelo fato da legislação ter colocado o professor coordenador na dependência da direção ou da supervisão, podendo gerar situações de certo "compadrio" que pode, em alguns lugares, definir quem exercerá a coordenação, como pudemos constatar em relatos já indicados.

Outras situações relacionadas às condições de trabalho, rotatividade do corpo docente, falta de funcionários e atropelos burocráticos interferem na prática do professor coordenador, promovendo desvio de função e um distanciamento entre o que se espera e o que é possível fazer. Outro aspecto enfatizado como dificuldade para o exercício da função é a indisciplina dos alunos que acaba sobrecarregando muitos professores coordenadores ao serem solicitados a resolver este tipo de questão.

Sendo assim, os relatos nos permitem afirmar que ainda são necessárias muitas mudanças na organização e estrutura da escola para que a função do professor coordenador seja desenvolvida com maior adequação e qualidade. Essas limitações no desempenho da função do professor coordenador podem, de alguma forma, interferir no desenvolvimento de políticas que tenham no trabalho desse profissional um dos pilares de sua execução.

Passaremos, a partir de agora, a apresentar e analisar os dados coletados nas entrevistas. A fim de organizar a apresentação, iniciaremos com os depoimentos relativos à progressão continuada e, na sequência, apresentaremos os que se relacionam ao SARESP. 
Uma das partes da entrevista feita com os professores coordenadores tinha como objetivo levantar as opiniões dos entrevistados acerca da implantação da progressão continuada. Algumas perguntas procuravam as impressões que o profissional teve da progressão continuada na época da sua implantação, ou seja, nos primeiros anos de vigência da medida e sua visão sobre ela a partir da sua atuação na coordenação pedagógica. Outras perguntas procuraram explorar questões relativas às orientações e formação que os entrevistados tiveram para trabalhar no regime de progressão continuada e como deveriam avaliar os alunos nesse contexto. Também essas questões procuravam obter informações da época em que estavam como professores na sala de aula e após a entrada para a coordenação.

Dos onze entrevistados, apenas dois já atuavam na coordenação pedagógica quando da adoção do regime de progressão continuada, as professoras coordenadoras PCIII e PCX. Os demais atuavam como professores e estavam ingressando na rede de ensino estadual ou ingressariam alguns anos depois.

As respostas dadas pelos entrevistados que atuavam nas séries iniciais do Ensino Fundamental revelaram uma impressão favorável à progressão continuada, considerando-a uma medida importante e que veio para enfrentar a questão da reprovação. Uma das entrevistadas ressaltou a importância da medida por trabalhar no ciclo básico e observou que durante a vigência deste a reprovação simplesmente se deslocava do final da $1^{\mathrm{a}}$ para o final da $2^{\mathrm{a}}$ série. A mesma entrevistada disse não ter sentido dificuldades com a adoção da progressão continuada, pois sua experiência no ciclo básico possibilitava a ela uma boa compreensão da medida adotada, tanto na teoria como na prática:

Só que o que acontecia é que esbarrava na $2^{\mathrm{a}}$ série, alguns ficavam ali até desistir da escola. Era o que acontecia dependendo da escola [...]. Quando veio a progressão continuada achei bom, só o ciclo básico não adiantava. Já tinha aluno na $2^{\mathrm{a}}$ série com 17 anos, ele acabava desestimulado. O aluno tinha uma ficha enorme, de tantas reprovações. Você ia preenchendo aquela ficha e a desse aluno era bem extensa. (PCI)

Os professores coordenadores que atuavam como professores a partir da $5^{\mathrm{a}}$ série revelaram que a primeira impressão que tiveram foi que era uma proposta inovadora, interessante, mas difícil de compreender e de se realizar na prática:

Se fosse bem compreendida seria muito boa. É válida, mas acho que foi compreendida de uma maneira errada pelos professores, pela comunidade e falando claramente, acho que ninguém entendeu muita coisa até hoje. (PCIII) 
Penso que ela funciona, dependendo do olhar que você tem para a coisa. (PCIV)

Acho a idéia válida, porém em algumas escolas os alunos, o próprio professor, acabam tendo uma visão diferenciada do que é a progressão. A progressão continuada deixou de ser aquilo "nós temos que passar todo mundo". Na realidade, para quem conhece a progressão continuada, não falaria desse jeito. Para você colocar na cabeça das pessoas o que realmente é, é muito difícil. (PCV)

Achei inovadora. Mas têm pessoas que acharam que a progressão continuada seria uma progressão automática. Que o aluno passaria sem saber nada, e não é assim. (PCVI)

Da maneira que chegou para os professores, como tudo chega, foi jogado. Num primeiro momento a palavra certa é essa, tudo chega muito jogado. Então a gente já vem projetando determinadas propostas. Só que da maneira como foi passado para os professores é muito difícil. (PCVII)

A fala dos entrevistados permite-nos confirmar o que pesquisas sobre a implantação da progressão continuada concluíram, ou seja, a medida é vista como inovadora, importante, enfrenta a questão da reprovação, mas a grande dificuldade está nas pessoas, sejam professores, alunos ou pais, compreenderem o significado dessa medida. O que usualmente ocorre é traduzir a progressão continuada como uma medida para que "todo mundo passe de ano", como promoção automática. Essa mesma afirmação havia sido evidenciada nas repostas obtidas nos questionários, como demonstrado no item anterior.

Ao explicitarem que a dificuldade de compreensão da progressão continuada se encontra na maneira como professores, alunos e famílias a vêem, colocam um problema que se refere a sua própria função, pois o que se espera do professor coordenador é ajudar alunos, pais e professores a compreenderem a progressão continuada. Muitos se colocam ou como se essa questão não se constituísse em um desafio para sua atuação ou como se sentissem impotentes para orientar os professores, principalmente a respeito da progressão continuada. Podemos exemplificar essa situação com a fala do PCV: "Só o coordenador dentro de uma escola não consegue pegar o professor e suprir suas defasagens, consegue apenas repassar as informações. O professor precisa de um curso, é difícil quando a pessoa está estagnada."

De um modo geral, as opiniões expressas pelos entrevistados revelam ausência de orientação e formação sobre o que é a progressão continuada e como deve o professor desenvolver o trabalho pedagógico nesse contexto, incluindo-se a questão da avaliação. Essa falta de orientação, apoio e formação também foi objeto de conclusões de teses e dissertações 
que tiveram a progressão continuada como tema de pesquisa e foram explicitados no primeiro capítulo deste estudo. Seguem algumas falas que ilustram a carência de formação:

Não, não me lembro exatamente. Mas do que me lembro a gente não teve. A gente sempre ouvia um texto aqui, um texto lá, mas eles não eram entrelaçados, cada professor ia tentando acertar. Não tinha uma direção, não era claro, ia tentando acertar, tentando fazer o melhor, mas não tínhamos uma organização. Enquanto professora de português se eu achasse que aquele era o momento de dar uma interpretação de texto focada no sujeito, trabalharia assim. Outra professora acharia que o momento era trabalhar objeto direto, ela trabalharia assim. É aí que eu acredito ter perdido o foco. (PCII)

No começo ninguém chega e te explica, ou te dá algum material para ler ou pesquisar. Simplesmente eles dizem que de hoje em diante funciona assim e vamos agir conforme o sistema. (PCIV)

$\mathrm{Na}$ época era tudo tão novo para nós quanto para o pessoal que deu orientação. Ficou meio no ar. Tudo que é início fica meio no ar, deixa a desejar. Nós tivemos a visão de que a progressão era passar todo mundo sem saber, sem controle, sem nada. Depois foi falado que a progressão não era isso, que era um acompanhamento. (PCV)

Como era uma coisa nova, cada um entendia de uma maneira, teve gente que ficou estático, teve gente que procurou saber, teve gente que entendeu que era progressão automática. (PCVI)

[...] tem que respeitar tudo o que o aluno fizer, se ele fizer; na época, depois foi tudo esclarecido, muito bem esclarecido. Grosseiramente dizendo se o aluno fizer um rabisco está certo, se ele conseguir escrever a letra A ele já está um pouco alfabetizado e assim por diante. (PCVII)

Sinceramente, não me lembro. Só que passaram a lei, recordo-me muito pouco. (PCXI)

Se, enquanto professores grande parte dos professores coordenadores relataram que não tiveram orientação ou que a orientação dada não foi suficiente devido à complexidade da medida, ao assumirem a coordenação alegaram receber orientações e formação em relação à progressão continuada, sendo apoiados principalmente pela Oficina Pedagógica:

Quando entrei para a coordenação alguns supervisores e ATPs vieram até a escola, ajudaram no HTPC. Na primeira escola que entrei como coordenador o grupo de professores era muito resistente, eu solicitei auxílio e tive apoio. A supervisora veio várias vezes na escola, no HTPC e ajudou a discutir o resultado dos alunos. Inclusive comecei a perceber que a Oficina Pedagógica começou a ficar mais preocupada, foi uma época que várias escolas tiveram problema com nota vermelha e retenção. Em várias reuniões pedagógicas que eu participei, falou-se sobre progressão, avaliação e tivemos algumas oficinas de como o professor avalia. Apoio para nós não faltou, sempre teve. (PCIX)

Teve, teve, inclusive até materiais que eles disponibilizavam para nós, enviavam, quanto a isso, sem sombra de dúvida. (PCVII) 
Quando eu era coordenadora, nós achamos por bem chamar os ATPs até a escola. Eu marcava com elas, elas vinham e no HTPC elas esclareciam algumas dúvidas que ficaram pendentes na minha explicação. Eu me orientava, pesquisava, lia para eles, mas buscava o respaldo da ATP. Vários ATPs e supervisores vieram aqui, eu ia chamando e elas iam passando as informações para os professores. (PCVI)

Enquanto coordenadora nós recebemos orientação. Fiz o circuito gestão, onde houve um estudo sobre isso, depois teve outro curso da secretaria, o pró-gestão, falou-se do gerenciamento da escola e voltamos a falar da progressão continuada. (PCIV)

$\mathrm{Na}$ fala dos entrevistados também pudemos perceber que houve uma mudança de compreensão do que é a progressão continuada com o tempo e com o exercício da função de professor coordenador:

Hoje entendo a progressão como uma forma de habilidade que o aluno tem. Ele está em defasagem em alguma disciplina não é justo que ele fique retido por um ano. Ele tem todo o ciclo para que ele elimine essa dificuldade. Vejo a progressão desse modo. $\mathrm{O}$ aluno de $5^{\mathrm{a}}$ a $8^{\mathrm{a}}$ série pode ter dificuldade na $5^{\mathrm{a}}$ série, vai ter o mesmo conteúdo na $6^{\mathrm{a}}$, na $7^{\mathrm{a}}$ e na $8^{\mathrm{a}}$ série. Vendo pelo lado de que a progressão continuada é uma forma de avaliar a habilidade que o aluno tem, ela é excelente. (PCVIII)

A progressão continuada deixou de ser aquilo "nós temos que passar todo mundo". Na realidade, para quem conhece a progressão continuada, não falaria desse jeito. Para você colocar na cabeça das pessoas o que realmente é, é muito difícil. (PCV)

Quando estava na sala de aula não havia compreendido isso, só comecei a entender a progressão continuada quando saí da sala de aula. [...] Comecei a entender melhor depois que saí da sala de aula, pensando nisso, o que tenho que trabalhar, o que tenho que garantir para o meu aluno. Quando a gente sai da sala começa a ver a coisa no todo, antes só olhava para minha disciplina, não pensava no todo, então foca numa coisa e fica perdido. Acho que ainda tem muito esse pensamento de deixar o aluno passar por falta de orientação e tentar passar essa credibilidade da progressão. (PCIV)

O que evidenciam os entrevistados é que o lugar da coordenação, as orientações e cursos que são oferecidos aos professores coordenadores pela Secretaria de Educação, por meio da Diretoria de Ensino, possibilitaram outro olhar, outra maneira de compreender o trabalho pedagógico e a progressão continuada. Enquanto atuavam como professores, desenvolvendo seu trabalho em sala de aula, no dia-a-dia com os alunos, não vislumbravam perspectivas e possibilidades que estar na coordenação proporcionou. Como revelado na opinião da PCIV: "só comecei a entender a progressão continuada quando saí da sala de aula”. 
Também pudemos identificar nas respostas dadas pelos professores coordenadores que todos eles propõem discussões acerca da progressão continuada e da avaliação em reuniões pedagógicas com os professores, nos conselhos bimestrais para discutir o rendimento dos estudantes e no acompanhamento cotidiano do trabalho docente. A dificuldade é que ainda enfrentam a resistência e a crítica de alguns professores, como demonstrou a PCVIII:

Todos os cursos de formação continuada de professores que eles iam, pedia o material; estudava com eles para socializar nos HTPCs. Nunca deixei o professor desinformado. Mesmo sabendo que havia resistências, professores que diziam que para mim era fácil por estar fora da sala de aula.

No tocante a avaliação, alguns professores coordenadores explicitaram que, na maioria das vezes, não foram orientados sobre como avaliar na época em que estavam na sala de aula, como podemos perceber na fala da PCIV: "No começo ninguém chega e te explica, ou te dá algum material para ler ou pesquisar. Simplesmente eles dizem que de hoje em diante funciona assim e vamos agir conforme o sistema." Essa fala reforça, também, o que as pesquisas indicadas no primeiro capítulo concluíram, que não houve preparo, orientação, participação dos professores em relação à progressão continuada e, por conseguinte, não foram orientados em como avaliar.

Portanto, as impressões reveladas sobre a progressão continuada e as orientações e formação recebidas neste período de vigência da medida não podem ser consideradas como suficientes na opinião dos professores coordenadores. Apesar das impressões serem bastante favoráveis, mesmo após tantos anos de implantação, ainda os professores coordenadores se ressentem da falta de uma orientação mais ampla por parte da Secretaria da Educação, além de cursos de formação continuada que realmente proporcionem essa discussão, propiciando aos professores uma melhor compreensão sobre a progressão continuada e de como avaliar nesse contexto.

Parte das questões feitas nas entrevistas com os professores coordenadores procurava coletar as opiniões dos entrevistados sobre o SARESP. Compreender como vêem o SARESP e como foram construindo suas opiniões acerca do mesmo permite-nos entender como essa política vem incidindo sobre a avaliação escolar. Iremos nos dedicar, a partir de agora, a explorar essas questões.

Algumas perguntas procuraram saber o que os professores coordenadores pensam sobre o SARESP, as impressões que eles têm dessa medida, que orientações e formação 
tiveram, como utilizam os resultados da avaliação externa e que ações desencadeiam com seus professores a partir dos resultados do desempenho dos alunos.

Como o SARESP foi implantado em 1996, quando realizamos as entrevistas havia 12 anos que a medida estava em vigor. Além disso, outro fator a considerar é que nesse tempo de existência o SARESP passou por mudanças, como abordado no segundo capítulo, o que significa dizer que em diferentes momentos a opinião dos professores coordenadores foi se modificando também.

Vale lembrar que os professores coordenadores entraram em contato com o SARESP, primeiramente, na condição de professores e depois como coordenadores, o que também revelou, pelas opiniões emitidas, que a compreensão sobre esta medida sofreu alterações quando o professor tornava-se professor coordenador.

Nos primeiros anos de vigência do SARESP os entrevistados revelaram preocupação, temor, desconfiança com relação ao SARESP. Segundo eles, não estava claro o que o governo pretendia com essa medida e muitos entenderam que era para avaliar o professor, outros que era para avaliar os alunos e ainda havia a idéia de que o SARESP serviria para aprovação ou reprovação dos estudantes. As falas seguintes são ilustrativas dessas impressões:

No início pensei que pudesse servir para reprovar o aluno, depois que seria para verificar como o professor estava ensinando. Hoje já vejo o SARESP como um modelo para gente avaliar e ver onde precisamos melhorar, não é para reprovar, nem para dizer o que está certo ou errado, mas para contextualizar o aluno dentro das necessidades que a sociedade e a situação profissional pedem. Vejo o SARESP como mais um modelo para gente ver onde é preciso melhorar, a equipe gestora, os alunos e os professores. (PCII)

Todo mundo ficou apavorado com a ideia de que seríamos avaliados como professores. E realmente avalia sim, também, o professor no SARESP. No início era muito complicado e quando os professores viram a prova ficaram com o cabelo em pé, porque era uma coisa que veio do Estado e não era a realidade da escola. (PCX)

Eu fiquei com medo, porque pensei que fosse para avaliar o trabalho do professor. Não tive uma orientação sobre o que seria o SARESP, foi tudo muito novo. Tudo foi muito novo, foi chegando e fui fazendo. Depois sim, houve uma orientação que a avaliação era para diagnosticar aquilo que realmente os alunos haviam aprendido. Mas você começa a se questionar, pois se veio uma prova, o aluno fez e não deu conta é porque minha aula não está funcionando. Essa foi a impressão que eu tive. (PCIII)

Que o SARESP era para avaliar o professor e não o aluno. (PCV)

Primeiro momento [...] eu gostei porque eu falei que é uma maneira de avaliar, esse primeiro, de avaliar como as escolas estão, como os alunos 
estão e como está sendo feito o trabalho. Mas sempre colocando que [...] é difícil você avaliar o trabalho de uma escola inteira com uma prova de um único dia. (PCVII)

No primeiro momento achei o SARESP fantástico, bom, o aluno vai se concentrar, vai ter uma prova e vamos poder trabalhar em cima desse resultado, desse diagnóstico. Mas, depois, comecei a perceber que era tudo isso mesmo, diagnóstico, poderia fazer o trabalho no ano seguinte em cima do resultado, só que o aluno não dava importância para o SARESP. (PCVIII)

Achavam que era para ver como o professor estava trabalhando, de que forma ele trabalhava. Avaliava os professores e não os alunos. Depois eles viram que era para avaliar o aluno mesmo, o que ele era capaz de fazer. (PCXI)

$\mathrm{Se}$, como dissemos, num primeiro momento os entrevistados tiveram preocupações e incertezas em relação ao SARESP, com o tempo e informações houve outro entendimento. Isso pode ser percebido nas falas anteriormente transcritas dos PCII, PCIII e PCXI. Nelas os professores coordenadores entendem o SARESP como um instrumento que avalia professores, alunos, a escola como um todo, tendo um caráter diagnóstico. As opiniões explicitadas pelos professores coordenadores evidenciam que essa compreensão não exclusiva deles, mas também de boa parte dos professores da escola.

Com relação aos alunos, alguns revelaram que, graças a um trabalho de conscientização feito pelos professores, também mudaram sua compreensão sobre o SARESP:

Os alunos são preocupados com a prova, fazem a prova com certa preocupação. Praticamente temos $100 \%$ de participação dos alunos. Isso é fruto de um trabalho que fizemos de conscientização. (PCXI)

O SARESP não vem para punir o aluno, veio como um termômetro para saber qual é o nível da escola, como os alunos estão, se precisam de ajuda, onde o professor tem que trabalhar, quais são as habilidades a serem trabalhadas. (PCIX)

No início nós ficamos preocupados. [...] O aluno também se preocupa, ele sabe que vai passar por uma avaliação, o que facilita o trabalho do professor na sala de aula. (PCIX)

Porém, muitos professores coordenadores identificam que o desinteresse dos alunos pela prova do SARESP é o maior problema, pois, em certos casos, o descompromisso em fazer a prova tem permanecido e essa displicência, na opinião dos entrevistados, pode interferir nos resultados da escola. Essa situação já havia sido anunciada nos relatos feitos nos questionários, sendo reafirmados nas entrevistas. Por isso, todos os entrevistados, mesmo aqueles que disseram não ter problemas com o envolvimento dos alunos, manifestaram preocupação com a necessidade de conscientizá-los da importância em fazer o SARESP: 
Quando o professor tem bem claro qual é a visão do SARESP, nesse sentido de melhoria, ele não tem problema com aluno em sala de aula. Ele não usa o SARESP como uma forma punitiva, porque o aluno, principalmente $o$ adolescente, se sentir punido reage não fazendo a prova. Por isso o aluno também precisa ser orientado, o SARESP vai mostrar o que a escola está realmente precisando. (PCIX)

Os outros professores também trabalharam, eles têm conhecimento da importância do SARESP, mas o aluno não, porque ele não é cobrado. (PCVIII)

[...] só que o aluno não dava importância para o SARESP. Não sabe o quanto a avaliação é importante para ele e para a escola. Por que, porque não tem uma cobrança em cima dele. Se ele não for fazer a prova ou não for bem o que acontece com ele, nada.

Muitos alunos vêm fazer a prova aleatoriamente, sem pensar, sem ter um porque de fazer a prova. Eles dizem que vão fazer a prova e ela não vai resolver nada mesmo. [...]

O aluno não tem mais perspectiva, não tem um mercado de trabalho. Tudo na vida é um toma lá dá cá. (PCV)

Os estudantes, provavelmente habituados a lógica da avaliação tradicional, marcada pelo condicionamento da nota, não vêem sentido em fazer uma prova que não gera uma nota, um conceito. Imbricados de uma lógica tradicional de avaliar, ao perguntar se vale nota ou o que acontecerá se não fizer a prova, obtendo a resposta de que não há nenhuma implicação ou punição, os alunos podem reagir não se envolvendo, com displicência e desinteresse pelo SARESP.

A esse respeito Vasconcellos (1998) comenta, acerca da avaliação da aprendizagem, que "um problema constante do cotidiano escolar diz respeito à grande preocupação dos alunos com a nota. Isto é constatado em qualquer sala de aula, dos menores aos maiores." (p.62). Importante destacar que os entrevistados indicaram que eles, assim como os professores, buscam na conscientização dos alunos um dos caminhos para solucionar este problema.

Uma prática evidenciada em situações vivenciadas em algumas escolas e identificada na fala de um dos entrevistados é a de atribuir uma nota ao SARESP que era utilizada na composição da nota bimestral dos alunos:

Na escola usamos o resultado do SARESP como uma das avaliações do bimestre. Se não sai logo o gabarito, antes do fechamento do bimestre, nós montamos um gabarito e corrigimos os cadernos de questões. Essa nota vai para a avaliação do bimestre. [...] vale para todas as matérias. A gente colocava para eles (alunos) que nós usamos a correção dos professores, pois o resultado oficial não sai a tempo. (PCXI) 
No tocante as orientações e formações que tiveram, os entrevistados responderam que enquanto eram professores e atuavam na sala de aula recebiam poucas orientações sobre o SARESP, geralmente no momento de aplicação da prova. Como professores coordenadores receberam mais orientações e tinham a responsabilidade de transmiti-las aos professores de suas escolas:

A gente sempre recebeu orientação, talvez não fosse a mais adequada. A diretoria de ensino nunca pegou e jogou as informações, nem sempre isso foi feito no momento adequado, da forma mais correta, mas sempre recebemos as informações e orientações. Enquanto professora recebia as orientações da direção. (PCII)

Como coordenadora continuei a receber as orientações sobre o SARESP, também dadas pela Oficina Pedagógica, pelos ATPs. Na escola, durante o HTPC, repassava para os professores as orientações que recebia na Diretoria de Ensino. Passava para todos os professores, independente da disciplina. (PCVI)

Antes da prova eram dadas as orientações, uns momentos antes. Tinham as orientações para aplicação e também para a correção. (PCX)

No começo eram reuniões na Oficina Pedagógica para aplicação. Recebia como coordenador e professor, pois na época era coordenador do noturno. Esse ano, por ter mudado a dinâmica do SARESP tivemos umas duas ou três orientações. Mas geralmente as orientações acontecem antecedendo o SARESP, perto da aplicação da prova, mas algumas orientações são dadas um pouco antes, avisando quando e como serão as provas. (PCV)

Os professores coordenadores que lecionavam Língua Portuguesa, quando estavam na sala de aula, revelaram receber mais orientações na condição de professor desta disciplina, principalmente devido à necessidade de correção da redação do SARESP, como evidenciado na fala da PCVI: "Éramos capacitados pela diretoria de ensino, eles levavam para nós cópias de redações e fazíamos a análise de acordo com os critérios de correção. Analisávamos redações de vários níveis para compreendermos o processo de correção".

Portanto, contrariamente ao que observamos em relação à progressão continuada, a cada aplicação do SARESP professores e professores coordenadores são orientados sobre como atuar, ao menos nos momentos de aplicação.

Ao perguntarmos quando e como utilizam os resultados do SARESP pudemos identificar, pelas falas dos entrevistados, que os resultados do SARESP, de um modo geral, são considerados no planejamento escolar. Fundamentalmente todos mencionaram trabalhar com os resultados nos momentos de planejamento, início do ano letivo, e de replanejamento, no início do $2^{\circ}$ semestre. 
Disseram que retomam os resultados sempre que necessário, principalmente nas reuniões pedagógicas (HTPC). Nos conselhos de classe e série bimestrais procuram cotejar os resultados do SARESP com a avaliação da aprendizagem feita pelo professor, refletindo sobre esses resultados.

Em relação aos usos dos resultados, basicamente identificam e analisam onde os alunos encontraram maior dificuldade, procurando adequar o planejamento curricular e das aulas para solucionar os problemas e melhorar o desempenho dos alunos. Na leitura dos resultados, durante o planejamento no início do ano, observam a posição da escola em relação às demais escolas da diretoria de ensino e do Estado.

Podemos dizer, em síntese, que os resultados do SARESP são utilizados como diagnóstico na orientação do planejamento escolar. Essa conclusão permite-nos afirmar que o SARESP está, cada vez mais, se engendrando no trabalho escolar. Algumas das falas dos entrevistados em relação aos usos dos resultados evidenciam essa situação:

Pegava os resultados do SARESP e também o rendimento de cada bimestre e discutíamos quando havia muita nota vermelha, perguntava o que estava acontecendo e o que podíamos fazer. [...] Cobrava não só o resultado do SARESP, mas também bimestral. Fazia uma ficha de acompanhamento e ia para a sala com o professor, analisava o trabalho dele, elogiava, levava para a direção e o professor lia. (PCVIII)

Pegamos o resultado do SARESP, faço um levantamento de dados para os professores. Observamos o que os alunos mais erraram, que habilidade estava pedindo na questão para saber o que precisamos trabalhar. A todo o momento nós usamos os dados das avaliações na escola, sempre tem um lembrete, uma coisa que lembre a todos os dados e os resultados. Essa é uma prática que temos a algum tempo, de sempre estar atento aos resultados. (PII)

Assim que os recebia. No planejamento levava os dados, discutia, via por que. Procurava identificar em quais questões os alunos tinham ido mal e por quê. Qual era o problema, se era de interpretação de texto. (PCV)

A gente sempre faz no planejamento. A prova é feita em outubro e o resultado chega no começo do ano. Nós mostramos o resultado para os professores e pegamos o resultado de outras escolas para vermos como estávamos em relação elas. Analisamos os níveis de proficiência, deu para elas verem bem a realidade da escola. (PCI)

A PCIV, ao falar sobre a utilização dos resultados do SARESP, demonstra uma preocupação não apenas com o SARESP, mas também com o desempenho dos alunos em outras avaliações, como a Provinha Brasil. Além disso, já indica uma preocupação com o 
Índice de Desenvolvimento da Educação no Estado de São Paulo, IDESP ${ }^{25}$. Introduzido recentemente, além de outros critérios, esse índice está vinculado ao desempenho no SARESP e as taxas de promoção e retenção, definindo as metas que a escola deverá atingir:

Sempre, a gente tem o SARESP no final do ano, os dados chegam e no planejamento a gente trabalha em cima dos resultados para estabelecer as metas e expectativas. O SARESP é uma avaliação externa, falo para as professoras que é a avaliação do SARESP que vai comparar a nossa escola com as outras. A partir daí a gente vai desenvolvendo o trabalho. Vou sempre retomando isto, no final do bimestre garantimos isso, em relação ao SARESP que competências já garantimos com eles. A todo o momento estamos indo e vindo, o IDESP, que está vindo agora, a provinha Brasil, são instrumentos a mais para direcionar o planejamento da proposta da escola. (PCIV)

Em relação a essa temática da premiação dos professores em função dos resultados das avaliações externas, Sousa (2008) evidencia que:

Um dos elementos que tem impulsionado os gestores a incorporar em suas políticas educacionais alternativas de premiação docente e de outros profissionais - ou de escolas por mérito ou produtividade - é a constatação de que escolas, e particularmente, seus profissionais não têm se mobilizado para enfrentar os baixos índices de desempenho que muitos alunos vêm reiteradamente apresentando nos testes que integram as avaliações em larga escala. Ou seja, os baixos desempenhos constatados por meio de testes usualmente não têm estimulado a busca por aprimoramento das políticas e práticas das escolas. (p. 82)

Entretanto, se não podemos generalizar, devido à natureza desta pesquisa, podemos identificar que um movimento, mesmo que incipiente, vem ocorrendo nas escolas no sentido de utilizar os resultados na tentativa de melhoria do desempenho dos alunos. Esse movimento manifesta-se nas falas dos entrevistados ao relatarem quando e como os resultados são utilizados. Há evidências que o desempenho dos alunos no SARESP tem norteado o planejamento escolar, como já indicamos e reafirmamos com os seguintes depoimentos dos entrevistados:

Nós usávamos no início do ano como [...] um indicador para o desenvolvimento de como planejar o trabalho dos professores. [...] nós pegávamos as provas, quais foram às questões que eles tiveram mais acertos e mais erros. Então era pontuado um trabalho específico em cima disso, independente do planejamento, do trabalho curricular do professor, era feito um trabalho em separado, em cima disso. (PCVII)

\footnotetext{
${ }^{25}$ Esclarecimentos sobre o IDESP foram dados no segundo capítulo deste trabalho.
} 
Pegava os resultados do SARESP e também o rendimento de cada bimestre e discutíamos quando havia muita nota vermelha, perguntava o que estava acontecendo e o que podíamos fazer. [...] Cobrava não só o resultado do SARESP, mas também bimestral. Fazia uma ficha de acompanhamento e ia para a sala com o professor, analisava o trabalho dele, elogiava, levava para a direção e o professor lia. (PCVIII)

Nós não esperávamos a chegada do resultado oficial. No ano passado nós já sabíamos que nossos alunos tinham ido mal em matemática. Era feito um trabalho com os professores e tabulávamos os dados. [...] Levava esses dados para o HTPC, no planejamento e no replanejamento. Trabalhávamos com os gráficos, inclusive os de redação. (PCIX)

É difícil para gente utilizar todo aquele material e passar para o professor, mas tinha um livrinho sobre as habilidades e competências. A gente pegava a prova e os resultados e cada professor analisava sua sala, o que precisava avançar e que habilidades desenvolverem. O professor procurava identificar onde os alunos haviam errado mais e trabalhava mais aquelas questões e habilidades. Fazíamos um gráfico e assim íamos trabalhando no dia-a-dia. Geralmente fazíamos a discussão quando chegava o resultado, o relatório, o gráfico, as habilidades, nós trabalhávamos a partir disso. (PCX)

Quando vem o oficial nós retomamos principalmente as questões em que os erros dos alunos foram maiores. Teria que trabalhar aquela questão ou competência que a maioria não aprendeu ainda. Assim que o resultado chega, quando chega depois do planejamento utilizamos nos HTPCs. Mesmo antes, usamos o resultado da correção que fizemos antes e quando chega o oficial fazemos nossa análise. A gente compara um ano com outro, aluno que está na $7^{\mathrm{a}}$ série, como foi na $6^{\mathrm{a}}$; o que precisa ser trabalhado novamente. (PCXI)

Perguntamos aos professores coordenadores que ações desencadeiam com seus professores a partir dos resultados do SARESP. Sousa, na citação anterior, afirma que "os baixos desempenhos constatados por meio de testes usualmente não têm estimulado a busca por aprimoramento das políticas e práticas das escolas". A questão apresentada aos entrevistados objetivava identificar ações que buscassem esse aprimoramento das práticas das escolas e obtivemos os seguintes relatos:

Pesquiso algumas aulas diferentes, aplicações de textos que não sejam comuns, que sejam mais interessantes para os alunos, até mesmo jogos que vão colocando texto no meio. [...] Estou sempre buscando e passo material para o professor e explico: vamos trabalhar assim; vamos tentar diferente; acho que eles vão gostar [...]. A professora de português do ensino fundamental trabalha, tem uma professora de português do ensino médio que é resistente. A professora do ensino fundamental é aberta, preocupada, vem mostrar o que está fazendo. (PCIII)

Percebo um empenho deles em trabalhar o que foi combinado, vejo isso como um aspecto positivo. Não está entrando por um ouvido e saindo pelo outro, os professores estão tentando, errar, erra. Mas o grande mérito é o empenho. Trabalho com profissionais que tem a consciência do seu dever, 
não entram na sala de aula e ficam enrolando. Até porque nós somos cobrados. (PCXI)

Quando você tabula o resultado do SARESP e vê que a sua turma não foi bem. Tem que redirecionar todinho o seu trabalho, pegar o plano de ensino do professor, ver o que foi trabalhado. [...] A gente começa a pensar, a partir dos resultados, como foi a base desses alunos. Aí você começa a fazer levantamento de conteúdo que foi trabalhado, você percebe que o trabalho não foi a contento e isso é prejudicial para o aluno. Não só para o aluno como para a escola também. Quando você percebe que o resultado está dentro da média você tem que trabalhar para que ele melhore cada vez mais. Mas se ele está abaixo da média, o trabalho é dobrado. Aí você tem que reunir o grupo de professores em HTPC, tem que começar a trabalhar o resultado do SARESP, questões do SARESP, analisar o plano de ensino do professor para ver como ele está trabalhando em sala de aula, se está contextualizando a disciplina. O trabalho é dobrado. [...] O professor que trabalha o conteúdo pelo conteúdo seus alunos não irão tão bem, ele vai procurar o colega. Aí que entra o coordenador, pega esses professores que entenderam o verdadeiro objetivo do SARESP e coloca esses professores para serem multiplicadores, para que conversem com os colegas e multiplique como ele está trabalhando na sala de aula. Isso é feito até hoje. (PCIX)

Os depoimentos dos entrevistados indicam uma preocupação em promover práticas pedagógicas que procurem enfrentar as dificuldades diagnosticadas no SARESP. A questão que se coloca é o quanto este movimento resulta da relação do SARESP com o IDESP e, consequentemente, se configure como indício da política de meritocracia que vem sendo, cada vez mais, implantada na rede estadual.

A centralidade da avaliação externa na política educacional do estado de São Paulo é revelada na escola com uma maior preocupação com o SARESP. Uma das críticas feitas às avaliações externas no Brasil é o seu poder de indução do currículo escolar. Sousa (2001) alerta que a avaliação externa não deve conformar o trabalho pedagógico, delimitando qual o conhecimento a escola deve legitimar.

A importância que o SARESP vem adquirindo para o funcionamento da rede estadual pode ser evidenciada em alguns depoimentos dos professores coordenadores:

Acho que o ensino está ficando vinculado ao SARESP. É bom porque a gente tem um rumo, mas, por outro lado, a gente fica vinculado a ele. "Olha, você vai aprender isso, por que senão vai mal no SARESP e aí vão dizer que eu não sou uma boa professora"; "Professora, onde vou usar isso? Não interessa, você tem que estudar porque vai cair no SARESP". Na prática vêm as competências e habilidades que você tem que trabalhar. Eu falei atrelado, mas não assim de um modo ruim. Por outro lado também cerceia. (PCVI) 
O SARESP [...] deu uma reviravolta, [...] Digo isso porque começaram a surgir os simulados nos moldes do SARESP. Isso de certa forma foi mudando a mentalidade do professor. (PCIX)

[...] de repente, virou uma coisa que a gente deveria trabalhar de acordo com o SARESP, tem que fazer o que vai ser no SARESP e não é. Temos que trabalhar habilidades para o aluno ser capaz de fazer uma prova como aquela. Eu senti isso, mudou o foco de que você tem que trabalhar para o SARESP. (PCIV)

Entendemos que essas falas dos entrevistados indicam que pode estar ocorrendo um direcionamento do currículo e do trabalho escolar pela avaliação externa. O SARESP não poderia direcionar o currículo, tornar-se a finalidade do trabalho do professor, deve apenas servir como um dos indicadores para a escola refletir sobre seu trabalho. Mas, como no depoimento do PCVI, pode inclusive tornar-se justificativa de por que o aluno deve estudar determinado conteúdo, ou seja, por "cair" no SARESP.

A PCIV mostrou, em seu depoimento, como o SARESP ganhou centralidade na escola em que trabalhava. Entretanto, em outro momento da entrevista, revelou ter mudado sua opinião, compreendendo o equívoco que seria direcionar o trabalho em função do SARESP:

As orientações que recebi foi sobre o que é o SARESP, que é instrumento de avaliação para ajudar no planejamento do professor, no desenvolvimento da escola, no plano de ensino da escola. Um pouco também da forma como ver a avaliação hoje, com meus professores, não daquela forma sabe ou não sabe. Quando entrei na coordenação pecava nesse sentido, começava a trabalhar em função do SARESP. Depois que estudei, por vários anos vi que você ensina, ensina, chega na prova a criança não consegue fazer e a escola não melhora, é porque tem alguma coisa errada, porque estamos trabalhando em função daquilo e não é isto.

A partir das opiniões coletadas, podemos considerar que, apesar de percebermos uma presença marcante do SARESP no trabalho escolar, ainda há muito que se fazer no sentido da avaliação externa ser utilizada em toda sua potencialidade pelas escolas, sem que estas percam a autonomia pedagógica e didática, mas subsidiando a definição de prioridades e encaminhamentos para aprimorar o trabalho desenvolvido.

Portanto, conclui-se que as impressões dos professores coordenadores entrevistados evidenciam que os professores estão empenhados em compreender o que é o SARESP, em utilizar de modo mais sistemático seus resultados e em promover práticas pedagógicas que favoreçam a melhoria do desempenho dos alunos nas provas.

Lembramos que o foco deste estudo foi o de identificar repercussões da progressão continuada e do SARESP na avaliação escolar. Ao indagarmos os professores coordenadores 
sobre eventuais repercussões da progressão continuada na avaliação escolar, as impressões variaram um pouco, não sendo possível chegar a uma opinião única, mas podemos dizer que de algum modo a progressão continuada vem repercutindo na avaliação da aprendizagem:

Avaliação não está mais como estávamos acostumados naquela época, avaliação no papel, avaliar o aluno no dia-a-dia, o tempo dele de escrever [...] A própria palavra já está dizendo, progressão, observar progressivamente e evolução do aluno na sua aprendizagem, não só da aprendizagem, mas sua desenvoltura na sala de aula, então tudo isso começou a ser avaliação. A avaliação na progressão continuada é isso, é respeitar o tempo do aluno. (PCVII)

Quando o professor entende o que é a progressão continuada o aluno se sente mais à vontade para aprender. E o professor não fica muito preso ao conteúdo. Uma pessoa que estudou a 20 anos atrás se ela voltar hoje na escola e entrar numa sala de aula vai estranhar muito. A aula é mais dinâmica, os alunos conversam mais. $\mathrm{O}$ aluno tem mais liberdade, mais diálogo entre professor e aluno. Não tem mais aquela imposição, só o professor fala, o professor é o dono da verdade. O professor passou a ser mediador entre os alunos. (PCIX)

As falas transcritas revelam que alguns professores procuraram compreender o significado da progressão continuada e buscaram promover mudanças em seu trabalho, incluindo a avaliação. A progressão continuada potencializa mudanças nas práticas escolares, mas o que percebemos é que mesmo nas manifestações que indicaram haver mudanças, explicitar de modo mais detalhado essas mudanças, principalmente na avaliação, foi muito difícil para os entrevistados. O depoimento da PCVI é revelador dessa dificuldade:

Avaliar o aluno cotidianamente, toda lição que você dá todos os dias, o aluno é avaliado. [...] orientei os professores a colocarem no papel quadriculado com o número do aluno e a data. Aí você vai marcando, quem tem o caderno em dia, se ele participou na lousa, se ele fez caça-palavras [...]. A progressão continuada vem daí. A supervisora fez acompanhamento da avaliação, o avaliar é somar tudo que ele fez, é avaliar o aluno por inteiro. [...] Se você avaliar o aluno todos os dias essa avaliação vai ser rica, vai ter mais dados, vai ter mais confiança no seu trabalho, você vê a criança de vários ângulos, então você não erra avaliando assim. Quando um aluno tira uma nota você dá consciente para ele.

O que percebemos por esse relato é que, com a progressão continuada, a idéia de avaliação contínua passou a fazer parte do discurso de professores coordenadores, afinal, está explicitada na legislação a necessidade da avaliação deixar de ser pontual, limitada a um ou dois instrumentos, para avaliar continuamente a evolução da aprendizagem do aluno. Em realidade, a proposição de uma avaliação com fins formativos não é nova na legislação federal e do estado de São Paulo. No entanto, com a implantação da progressão continuada esta visão de avaliação ganha destaque, constituindo-se em uma noção nuclear da organização do ensino. 
A PCVI procurou relatar como orientou os professores na realização dessa avaliação contínua e cotidiana e inclusive sua forma de registro. Mas, pelas informações por ela prestadas, fica difícil perceber uma mudança de concepção na avaliação, de uma perspectiva mais tradicional, para uma avaliação mais formativa. Embora revele a intenção de valorizar todas as atividades desenvolvidas em sala de aula pelos alunos, isso se traduz na multiplicação de instrumentos de avaliação.

Nas orientações feitas aos professores, a professora coordenadora indica que eles devem ir "marcando quem tem o caderno em dia, se ele participou na lousa, se ele fez caçapalavras", direciona para um registro de quem cumpre as tarefas em sala de aula, mas não revela uma análise dessas atividades, apontando as dificuldades apresentadas pelos alunos e, a partir delas, uma reflexão e planejamento das práticas pedagógicas.

Se considerarmos a conhecida questão colocada por Luckesi (1999), qual seja, “verificação ou avaliação: o que pratica a escola?”, podemos afirmar que, no registro da fala da PCVI, predomina a verificação em detrimento de uma perspectiva formativa, o que caracterizaria a idéia de avaliação, como expressa por Luckesi:

A avaliação, diferentemente da verificação, envolve um ato que ultrapassa a obtenção da configuração do objeto, exigindo decisão do que fazer ante ou com ele. A verificação é uma ação que "congela" o objeto; a avaliação, por sua vez, direciona o objeto numa trilha dinâmica de ação. [...] O uso dos resultados tem se encerrado na obtenção e do registro da configuração da aprendizagem do educando, nada decorrendo daí. (p. 93)

Nesse sentido, o relato da PCVI, apesar de indicar uma mudança nas práticas avaliativas, não revela uma ressignificação da avaliação, pois restringe o uso dos dados coletados sobre a aprendizagem ao registro e a atribuição de nota.

O PCIX também relatou ter percebido mudanças na avaliação feita pelos professores:

Percebo é que há mais diálogo entre professores e alunos. Quando eu iniciei, a fala do conselho, na maioria, os professores eram mais rígidos, mais duros. Hoje a mentalidade mudou. A gente ainda tem uma minoria resistente. Mas na forma de avaliação ele está mais flexível. O aluno tirou uma nota vermelha, o professor já da uma recuperação. Conheço professores que depois do horário fica na sala de aula com o aluno, explicando.

Esse relato indica que ocorreu, em função da progressão continuada, mudança na relação do professor com os alunos. Essa mudança pode ser identificada na flexibilidade citada pelo professor coordenador em relação à avaliação. Nesse sentido, o que o professor coordenador explicita é que o professor já considera o processo de recuperação como um 
momento inerente ao processo de aprendizagem e não mais um apêndice ao final do bimestre ou ano. Entretanto, a ênfase na nota vermelha como critério para proporcionar ao aluno recuperação, pode revelar a permanência de recuperação da nota e não, necessariamente, da aprendizagem.

Vasconcellos, quando discute sobre a mudança na avaliação e reflete acerca da recuperação da aprendizagem, evidencia que:

Recuperar a aprendizagem não é "repetir a explicação"; trata-se de conceber e organizar situações que possam favorecer a efetiva construção do conhecimento; é procurar outras formas de abordagem do mesmo assunto/conceito junto ao aluno (e não a mera reiteração do discurso e das estratégias). É trabalhar a partir de onde o aluno está (e não de onde se gostaria que estivesse...); é ajudar o aluno a se reintegrar no processo de aprendizagem, respeitando o seu ritmo e suas experiências de vida adequando os conteúdos e métodos aos seus estágios de desenvolvimento. (grifos do autor) (1998, p. 37)

Por outro lado, ao informar que alguns professores permanecem mais tempo na sala de aula para atender as dificuldades dos alunos e observar que no conselho de classe estão mais flexíveis, dá indicações que pode haver uma tendência, conforme propõe Hadji (2001), de "pôr a avaliação a serviço das aprendizagens o máximo possível” (p.15).

Vale lembrar que o relato do PCIX, anteriormente citado, contém perspectivas de mudança na avaliação de um modo geral, explicitando que uma minoria dos professores mantém uma postura resistente. Já o relato da PCVIII é menos otimista em relação à mudança na avaliação em função da progressão continuada:

Apesar da reprovação e da evasão terem diminuído, na prática dos professores não percebi mudança, principalmente na forma de avaliar. $\mathrm{O}$ professor, no conselho de classe, diz que deu 5 ou 6 atividades e que o aluno não fez nenhuma e por isso ficará com vermelho. Você percebe que o professor só quis aquele papel para ele corrigir. Se o aluno não entregou ou se entregou e está errado o professor não mediu mais nada. A folha escrita para colocar certo e errado, não dá devolutiva para o aluno, retomar as dificuldades, isso não existe e deveria fazer parte. Você tem que ver onde o aluno está com dificuldade. Se você não observa se ele está com dificuldade como saber se ele avançou? O professor não se preocupa em dar uma devolutiva. A maioria dos professores não tem essa prática, mesmo os mais antigos.

O depoimento desta professora coordenadora revela a dificuldade em se realizar mudanças na avaliação. Apesar dos professores não permanecerem, como tradicionalmente se fazia, aplicando duas provas e dividindo por dois para tirar média, aplicar um número maior 
de instrumentos e não analisar as dificuldades dos alunos não representa avanço em direção a uma avaliação processual, como se espera que aconteça no regime de progressão continuada.

A esse respeito, Vasconcellos nos alerta que:

Para que a avaliação seja um instrumento de ajuda, deve ser reenfocada desde raiz. Muitas vezes, tenta-se inovar, mas não se supera o núcleo do problema; considera-se, por exemplo, que se mudou totalmente só porque, agora, aplicam-se vários instrumentos de avaliação; no entanto, se eles não forem utilizados para captar as necessidades dos alunos e superá-las, continuar-se-á orbitando o "mundo da nota", da lógica classificatória. (1998, p. 20)

Importante ressaltar que as mudanças citadas nos depoimentos dados pelos professores coordenadores em função da progressão continuada, assim como as opiniões que haviam sido expressas nos questionários, não indicam um redirecionamento da finalidade classificatória e excludente da avaliação, revelando o desenvolvimento de uma avaliação formativa.

Quanto às repercussões do SARESP na avaliação escolar, os professores coordenadores demonstraram facilidade em indicar algumas alterações que eles identificam como decorrentes dessa iniciativa. Uma dessas alterações é a aplicação de testes, pois, segundo eles, com progressão continuada os professores pararam de aplicar provas e avaliavam continuamente. Com o SARESP houve a necessidade de retomar a aplicação das provas, principalmente nos moldes da prova do SARESP, para familiarizar os alunos com este tipo de instrumento:

Sim, houve a aplicação de simulado. Nós percebemos que os alunos não estão acostumados com o SARESP. Como passamos a avaliar cotidianamente os alunos, as provas bimestrais ficaram de lado. Eu mesma, na sala de aula, não fazia mais. O aluno, então, ficou sem saber o que é uma prova, então, passamos a fazer os simulados e preparando o aluno para o SARESP mesmo. Tem que preparar a criança, se não no dia da prova fica mais difícil. Nós corrigimos o simulado, seguimos os moldes do SARESP, identificamos onde estão errando mais, mas não damos nota para média do aluno. Só para preparar para o SARESP. O professor trabalha a prova com eles depois, para que entendam o que erraram. Inclusive o professor tenta compreender porque eles erraram. (PCI)

Este relato revela uma mudança na prática da avaliação, ou seja, a aplicação de simulados, tendo como referência a prova do SARESP, mas também evidencia que há uma reflexão sobre as dificuldades do aluno e uma análise dos erros cometidos. Apesar de não ter explicitado ações decorrentes dessa avaliação, no sentido de garantia da aprendizagem, as indicações feitas revelam uma preocupação que poderíamos considerar formativa na aplicação deste instrumento. 
A PCIV não especificou, em seu depoimento, mudança na avaliação, mas nas práticas escolares como um todo, o que possibilita pensarmos que também se processaram mudanças na avaliação:

Todo mundo vem trabalhando com a idéia de que a gente tem que ir bem no SARESP. Comecei a colocar para elas que o SARESP é um instrumento de avaliação que vai ajudar a nortear o trabalho na escola. Para fazer essa avaliação o aluno precisará adquirir algumas habilidades e essas habilidades estão dentro das competências que estão no currículo que eu tenho que garantir. Converso com elas que a gente tem que desenvolver as habilidades de leitura e escrita, então trabalhamos em função disso, porque se garantirmos isso quando vier o SARESP o aluno terá condições de fazer. Não sei se é bem em função do SARESP que fazemos isso, mas norteou um pouco.

O PCV, assim como a PCIV, não explicita mudanças mais efetivas e concretas com exemplos da prática, mas anuncia, em seu depoimento, que o SARESP ocupa um papel central na avaliação escolar:

Tudo é feito em cima do SARESP, todas as nossas avaliações. Tudo o que nós fazemos é pensando no SARESP, projetos de leitura, exercícios. Pegamos a prova e vemos as dificuldades e trabalhamos. Tudo é feito em função do resultado, pois é injusto a gente trabalhar tanto e ter um resultado negativo na escola.

As manifestações acerca da influência do SARESP na avaliação escolar são reveladoras do potencial que essa medida apresenta em reorientar as práticas escolares, pois, os depoimentos demonstram haver uma preocupação dos professores em preparar os alunos para o SARESP, seja com simulados, com análise dos resultados ou com enfoque em habilidades e competências.

Ficou evidente, nas falas dos professores coordenadores, que o SARESP tem o potencial, inclusive, de estimular o trabalho escolar, como demonstra o relato do PCVI:

Agora os professores, alunos e pais estão centrados. Eles já sabem que os filhos têm que estudar, que eles têm que estar aptos. Eles sabem que o SARESP vem atender a demanda que está aí fora. Então, se o aluno for bem no SARESP, vai bem em qualquer teste ou prova que for fazer.

A PCII, em seu relato, exemplificou a mudança na avaliação influenciada pelo SARESP na professora de Matemática:

Mudou sim, tenho especificamente uma professora de matemática. Antes ela via a avaliação de um determinado modo, hoje ela consegue montar uma prova de matemática bem próxima a do SARESP. Ela já contextualiza, ela cresceu muito como profissional. Acompanhei essa professora, ela cresceu 
muito profissionalmente, apesar de não ser efetiva, mudou muito sua forma de avaliar a partir do SARESP.

Considera a PCII que elaborar uma prova como o SARESP implica no desenvolvimento de uma capacidade que antes a professora não tinha e que, ao ser capaz de fazê-lo, há um crescimento profissional. Portanto, isso indica o quanto ela considera o SARESP como referencial para nortear a avaliação e as práticas escolares.

A PCIV evidencia o potencial que o SARESP tem de promover e orientar práticas avaliativas na escola em que atua:

Antes tinha uma prova bimestral que o professor dava. Combinei com as professoras de elas trabalharem durante o semestre e no final do semestre fazemos uma avaliação, como se fosse um SARESP. Troco os professores de sala, fazemos toda a aplicação como no SARESP para as crianças sentirem como é o SARESP, já que sabemos que todo ano essa avaliação. Montamos uma avaliação de acordo com tudo que foi proposto no $1^{\circ}$ semestre, para ver se $\mathrm{o}$ professor garantiu aquilo. $\mathrm{Na} 1^{\mathrm{a}}$ série faço uma avaliação para identificar se garantiram o sistema de escrita, para ver se os alunos têm mais autonomia para fazer aquilo. Durante todo ano os professores estão fazendo essa avaliação rotineira com eles, é mais uma avaliação unificada para verificar se a escola atingiu a meta proposta para o semestre. Falei de simulado porque em 2006 como não houve SARESP nós fizemos um simulado. A diretoria de ensino, inclusive, orientou que as escolas fizessem uma avaliação para fazer um comparativo $e$ ver se houve um desenvolvimento. Tanto que o SARESP de 2007 foi comparado pela Secretaria com o de 2005, já que não houve em 2006. O simulado foi somente em 2006, para termos dados e trabalhar em 2008.

O relato desta professora coordenadora é revelador do quanto o SARESP vem norteando o trabalho escolar. Se com a progressão continuada, conforme explicitado nas falas dos entrevistados, a prova foi sendo abandonada, com o SARESP ela é resgatada e segue o seu modelo, não apenas no tocante ao instrumento, mas também em relação aos procedimentos de aplicação. A avaliação organizada pela escola passa ter com o SARESP, em algumas escolas, o objetivo verificar o que o professor conseguiu garantir na aprendizagem dos alunos e a meta estabelecida para aquele semestre ou ano.

A fala da PCIV traz uma informação do quanto o SARESP tem se tornado central no trabalho escolar, pois no ano em que a Secretaria da Educação suspendeu a prova (2006) houve uma recomendação da Diretoria de Ensino para que se fizesse uma prova no lugar do SARESP. Segundo a PCIV o objetivo da prova seria "para fazer um comparativo e ver se houve um desenvolvimento," o que nos leva a pensar que a escola vem considerando como parâmetro para avaliar seu desempenho apenas a avaliação externa e que na sua ausência os 
dados coletados pelos processos internos de avaliação não são considerados suficientes para avaliar a escola.

Outro relato que evidencia como o SARESP orienta o trabalho escolar foi feito pela PCII:

\begin{abstract}
Num primeiro momento sempre ouvia que o problema era o desinteresse do aluno, que eles não leram a prova, que entregaram muito rápido, que eles não se preocupam com esse tipo de avaliação. Por causa dessa fala que nós começamos um trabalho de conscientização dos alunos. Posso garantir para o professor na prática, porque eu fico do lado dele, que o aluno está se conscientizando, para poder argumentar com o professor e conscientizá-lo também. A gente tinha essa fala, que não tinham interesse, perspectiva. Resolvemos levar as provas internas com mais seriedade, para conscientizar o aluno que ele precisa ler e saber onde está a dificuldade dele e o professor trabalhar. Que eles entendam que a prova não tem o objetivo de ser punitiva, mas que tem outro lado, para ver onde ele precisa de ajuda. Falo para os alunos que não adianta eles colarem do colega, precisamos saber onde está a dificuldade para que possamos ajudá-los.
\end{abstract}

A preocupação dos professores com o desinteresse dos alunos em realizarem o SARESP é que desencadeou todo um movimento no sentido de conscientizá-los a fazer a prova. Provavelmente, o desinteresse dos alunos deve-se ao condicionamento da nota, já que devido a esse condicionamento eles não veriam sentido numa prova que não lhes atribui nota ou reprova. Interessante ressaltar que essa conscientização, segundo a PCII, foi necessária não somente em relação aos alunos, mas também em relação aos professores.

Ainda nesse mesmo relato podemos observar que a professora coordenadora diz que "resolvemos levar as provas internas com mais seriedade, para conscientizar o aluno que ele precisa ler e saber onde está a dificuldade dele e o professor trabalhar". Essa fala evidencia o quanto o SARESP está influenciando na avaliação da aprendizagem nesta escola, primeiro fazendo com que a prova, enquanto instrumento de avaliação, seja valorizada e enfatizando a necessidade de alunos e professores identificarem os erros e as dificuldades de aprendizagem. Essas indicações podem favorecer a compreensão do papel diagnóstico da avaliação e orientar as práticas pedagógicas.

Além disso, a necessidade de fazer com que as provas internas sejam levadas com seriedade poderia ser entendida no contexto de perda de credibilidade das avaliações feitas pelos professores, muito provavelmente, em função da progressão continuada. Isso nos leva a pensar que enquanto a progressão continuada desestabilizou a avaliação praticada nas escolas, eliminando a possibilidade da reprovação entre as séries, finalidade que tradicionalmente a 
avaliação desempenhou; a preocupação com o SARESP fez com que a escola voltasse a aplicar provas, mas com a finalidade de garantir um bom desempenho dos alunos na avaliação externa.

Ao perguntarmos aos entrevistados qual medida estaria incidindo mais sobre as práticas avaliativas e escolares, de um modo geral, os professores coordenadores responderam que seria o SARESP:

O SARESP por ser uma avaliação externa, por servir como termômetro, diagnóstico para o ano seguinte, o professor está mais informado sobre o SARESP. A própria secretaria manda mais informação, material, sobre o SARESP, mas em relação à progressão continuada não há essa preocupação. Outra coisa é devido ao bônus, anteriormente aquelas cores da escola, os professores se preocupam muito com isso, ao contrário da progressão continuada. (PCVIII)

Acho que nesse momento é o SARESP. Porque a gente ainda se depara com professor que quer reprovar o aluno. Aquele aluno está com dificuldade, mas a gente tem que ver qual é a dificuldade, o que podemos fazer para sanar essa dificuldade. O professor escreve na ficha que o aluno não sabe produzir texto, mas estou trabalhando isso com ele? De que forma estou trabalhando? Tem professor que quer chegar ao final do ano e falar que ele não sabe produzir texto e vai ser retido. Mas e o trabalho que foi feito durante o ano, tenho que trabalhar com ele, ler, ensinar. Para alguns é mais fácil reprovar, no ano seguinte ele faz de novo e aprende. (PCI)

Esses depoimentos indicam que o SARESP incide mais sobre o trabalho escolar, incluindo-se as práticas avaliativas. Um aspecto apontado pela PCVIII evidencia que a Secretaria de Educação se preocupa em informar e orientar em relação ao SARESP e o mesmo não ocorre com a progressão continuada. Essa opinião se confirmou quando, no capítulo anterior, exploramos as questões a respeito da implantação dessas medidas e concluímos que informações e orientações sobre a avaliação externa são mais intensas que sobre a progressão continuada.

A PCVII justifica que o SARESP incide mais sobre as práticas avaliativas devido ao bônus e o histórico existente de premiação e punição das escolas. Haveria uma preocupação dos professores em relação ao ranqueamento das escolas e a posição que sua escola ocuparia em relação às demais. Se a classificação e o bônus mobilizam os professores, como afirmou a entrevistada, podemos dizer que essa postura evidencia que a finalidade classificatória e excludente da avaliação, tanto questionada com a adoção da progressão continuada, mostra sua força quando o professor se considera avaliado, premiado ou punido. 
A permanência da cultura da repetência revela-se com o depoimento da PCI, pois ela indica que professores ainda manifestam o desejo de reprovar os alunos que apresentam dificuldades de aprendizagem e, ao que parece, não assimilaram a idéia de que a avaliação deve ser contínua, processual, formativa, como recomendada no contexto da progressão continuada. Importante lembrar que nas respostas dadas nos questionários e anteriormente analisadas, a permanência da necessidade de reprovação como estímulo aos alunos havia sido amplamente registrada.

Para a PCXI a progressão continuada e o SARESP são medidas que apresentam lógicas distintas, pois "cada um caminha para um lado. Porque a progressão continuada trabalha com a progressão do aluno, ele progrediu ou não. O SARESP vem medir, como vou dizer; os conhecimentos específicos”. Essa é a especificidade do SARESP que lhe permite servir aos professores "como termômetro, diagnóstico para o ano seguinte" (PCVIII), enquanto a progressão continuada, ao desestabilizar as bases em que se fundamentavam as práticas avaliativas desenvolvidas na maioria das escolas, "ficou meio solta, não teve a devida atenção dentro das escolas o que realmente era a progressão. Na cabeça do professor ele não pode reprovar, tem que passar o aluno, mesmo sem ele saber". (PCXI)

As impressões descritas indicam que se os professores têm buscado apropriar-se do SARESP, utilizar os resultados, reformular seu trabalho e isso repercute nas práticas avaliativas, a progressão continuada, ao contrário, ainda é pouco compreendida. O que se evidenciou foi que muitos professores aprenderam a conviver com ela, mantendo uma concepção e práticas tradicionais de avaliação. Essas impressões também são evidenciadas no seguinte depoimento:

A medida que teve mais impacto nas práticas avaliativas foi o SARESP. Porque o SARESP contribuiu mais para o amadurecimento profissional dos professores, eles conseguiram ter outra visão. Antes o professor montava sua prova e aplicava para sua turma. Hoje ele mostra para os colegas, mostra para mim, procura compartilhar. O SARESP conseguiu proporcionar isso para os professores, eles passaram a trocar mais idéias em relação à avaliação. Tanto a progressão continuada como o SARESP tiveram uma contribuição nessa formação dos professores, não consigo separar essas duas coisas. O SARESP deu uma contribuição de $80 \%$ e a progressão uma contribuição menor, mas os dois contribuíram para a formação do professor. Talvez a progressão continuada tenha contribuído menos porque o professor há alguns anos está na rede, essa transição da cultura da repetência ainda está presente na fala de alguns professores, ainda ouço que "antes era melhor"; "ah se eu pudesse reprovar o aluno". (PCII) 
O que percebemos com as impressões manifestas pelos entrevistados é que a centralidade da avaliação na promoção ou retenção dos alunos com a progressão continuada tenderia a deslocar-se para a aprendizagem. Entretanto, o que estamos identificando é que o SARESP tem assumido essa centralidade. Ao tirar o norte no qual se assentava, tradicionalmente, o trabalho escolar, a progressão continuada possibilitou ao SARESP assumir o papel de bússola na busca de novos rumos.

O relato a seguir demonstra o papel que o SARESP está desempenhando na orientação do trabalho escolar:

Em relação ao SARESP já tem uma compreensão melhor. Os professores sabem que é uma avaliação externa, avaliando o desempenho dos alunos. Com a nova proposta amarrou mais, porque também era solto. O professor que determinava o conteúdo que ele queria, agora ficou mais amarrado, vejo mais ligação. O que vai ser cobrado e o que está sendo trabalhado. Antes eram cobradas coisas que não se trabalhava, como por exemplo, geometria. A alegação era que não dava tempo. A visão real da escola vai ser apresentada nessas avaliações. Agora a gente sabe que conteúdos serão cobrados. O que o professor deve trabalhar. É o que se espera, que a avaliação seja feita em cima dos conteúdos indicados pelo Estado. (PCXI)

Ao mencionar a "nova proposta", a PCXI faz referência à implantação que se processou no ano de 2008 de um currículo oficial para a rede estadual paulista ${ }^{26}$. Uma das justificativas da Secretaria da Educação para a implantação do novo currículo foi a ausência de um currículo unificado, existindo muitas disparidades entre o que era trabalhado nas escolas. Essa diversidade dificultaria o desempenho dos alunos no SARESP, portanto, unificando o currículo os professores iriam trabalhar o que realmente seria cobrado no SARESP, como manifestado na opinião anteriormente transcrita.

Ao organizar do ensino em ciclos e se adotar o regime de progressão continuada faz-se necessário, de acordo com vários estudiosos desta temática, reorganizar o currículo, o que pode ser identificado em redes cicladas que, no momento de adoção das medidas, promoveram esse movimento, a exemplo das redes municipais de São Paulo (1992)

\footnotetext{
${ }^{26}$ No início do ano de 2008 a Secretaria de Educação lançou uma nova proposta curricular com conteúdos, habilidades e competências a serem trabalhados e desenvolvidos no Ciclo II do Ensino Fundamental e Ensino Médio. Para cada série e disciplina foram elaborados cadernos para os professores com atividades, chamadas de situações de aprendizagem, para cada tema constante na proposta curricular. O objetivo desses cadernos seria de orientar as práticas pedagógicas na implantação da nova proposta curricular. Em 2009, além dos cadernos para os professores também estão sendo elaborados cadernos com as atividades para os alunos. Maiores informações sobre o currículo oficial do Estado de São Paulo podem ser encontradas no site: www.sãopaulofazescola.sp.gov.br.
} 
(ALAVARSE, 2002; CORTELLA, 1992) e Belo Horizonte (1994) (ARROYO, 1999; DALBEN, 2000; SOUSA e BARRETTO, 2004). No caso da rede estadual de São Paulo, os ciclos implantados em 1998, não foram acompanhados de um movimento de reorientação curricular que visasse discutir e adequar o currículo na organização em ciclos.

No depoimento da PCXI, identificamos que a proposição de um novo currículo para a rede pública estadual teve como motivador, ao menos na visão da entrevistada, a avaliação externa. Além disso, apesar de não se verificar, por parte da Secretaria de Educação, um amplo debate com a rede no sentido de construir coletivamente a proposta curricular a ser implantada, não houve manifestação nas opiniões dos entrevistados de reação contra essa medida, mas de aceitação por parte dos professores, devido, talvez, a vinculação do novo currículo ao SARESP.

A progressão continuada preconiza, como indicamos no primeiro capítulo deste estudo, uma avaliação contínua, processual, formativa, assim definida por Fernandes e Freitas (2008):

A avaliação formativa é aquela em que o professor está atento aos processos e às aprendizagens de seus estudantes. O professor não avalia com o propósito de dar uma nota, pois dentro de uma lógica formativa, a nota é uma decorrência do processo e não o seu fim último. O professor entende que a avaliação é essencial para dar prosseguimento aos percursos de aprendizagem. Continuamente, ela faz parte do cotidiano das tarefas propostas, das observações atentas do professor, das práticas de sala de aula. Por fim, podemos dizer que a avaliação formativa é aquela que orienta os estudantes para a realização de seus trabalhos e de suas aprendizagens, ajudando-os a localizar suas dificuldades e suas potencialidades, redirecionando-os em seus percursos (p.22).

O SARESP, atrelado a um currículo unificado, tenderia a reforçar práticas avaliativas mais tradicionais, como pudemos evidenciar em práticas descritas pelos entrevistados. A preocupação em ensinar todos os conteúdos presentes no currículo unificado pode comprometer uma das noções mais elementares presentes na idéia da progressão continuada e dos ciclos que é a de que os alunos podem apresentar ritmos diferenciados de aprendizagem. Além disso, a flexibilidade curricular necessária para atender as necessidades e ritmos diferenciados dos alunos ficaria comprometida.

Se o SARESP adquirir uma centralidade cada vez maior, como evidenciamos nos depoimentos dos entrevistados, a lógica de uma avaliação formativa, implícita na idéia da progressão continuada, poderia estar comprometida em função de uma lógica classificatória, 
não mais centrada no aluno, mas no desempenho da escola e do professor, impulsionados pela meritocracia implementada pelo IDESP e pelo pagamento do bônus.

O cenário que se descortina para a avaliação escolar ainda não pode ser completamente vislumbrado, mas podemos concluir que a tendência é cada vez maior de uma centralidade das práticas escolares em torno do SARESP.

\subsection{Revelações da pesquisa: uma visão sintética}

Neste item procuraremos sistematizar o que revelam os depoimentos dos professores coordenadores. As respostas nas entrevistas não conflitaram com o que foi coletado nos questionários e permitiram um aprofundamento acerca das impressões dos professores coordenadores em relação à progressão continuada, ao SARESP e à avaliação escolar.

\section{Progressão continuada e as mudanças nas práticas avaliativas}

Em relação à progressão continuada podemos afirmar que a medida vem impactando o trabalho pedagógico desde sua implantação. As pesquisas acadêmicas mencionadas no primeiro capítulo já indicavam esse impacto, desestabilizando as práticas escolares e avaliativas, o que pudemos confirmar nos dados coletados neste estudo.

Foi evidenciado pelos professores coordenadores que os professores, os pais e os alunos compreenderam a introdução da progressão continuada como aprovação automática, o que gerou o descontentamento dos docentes, por não conseguirem mais orientar suas práticas pela lógica da promoção/retenção e o desestímulo dos alunos, por não verem mais sentido em estudar. A este respeito, Vianna (2003) fez o seguinte comentário:

[...] a chamada progressão continuada, impropriamente chamada de promoção automática, denominação que inclusive concorreu para o seu desvirtuamento, ainda não é bem aceita pela comunidade, apesar de esforços para esclarecimentos da sua lógica e do seu significado, que pressupõem constante uso de diferentes tipos de trabalho avaliativo em todos os momentos do processo educacional. (p.29-30) 
Se nos primeiros anos de vigência da progressão continuada identificamos um movimento oscilante entre a incompreensão e a resistência, com o tempo percebemos ocorrer uma acomodação e indiferença em relação à progressão continuada. Provavelmente, parte dessa situação, se explica, de acordo com o relato dos professores coordenadores, pelo fato de não haverem orientações, esclarecimentos e formação suficiente para estimular os professores a compreenderem essa medida e a promoverem práticas avaliativas formativas.

Um movimento identificado no relato dos entrevistados, no sentido de mudar práticas avaliativas, ocorreu em relação à aplicação de provas para avaliar os estudantes. Com a progressão continuada as provas foram relacionadas às práticas tradicionais de avaliar na escola. Com isso, muitos professores, segundo os entrevistados, não utilizaram mais a prova como instrumento de avaliação, até mesmo porque procuravam diversificar os momentos e as práticas avaliativas como determinado na legislação vigente.

Entretanto, essa situação é reveladora de uma incompreensão gerada pela falta de informações acerca da concepção de avaliação que norteia a idéia da progressão continuada. Em relação à aplicação de provas não podemos considerar que ela seja um problema, pois a dificuldade não se situa, necessariamente, no instrumento, mas sim no uso que é feito do resultado obtido nas provas. O que foi evidenciado nos depoimentos dos professores coordenadores é que houve uma diminuição na aplicação das provas, utilizando-se outros instrumentos, mas não ocorreu uma mudança no uso dos resultados, permanecendo, com muita força a necessidade de atribuição de notas.

Ao refletirem sobre a concepção formativa de avaliação e suas práticas na escola, Fernandes e Freitas (2008) evidenciam que:

O professor, trabalhando na perspectiva da avaliação formativa, não está preocupado no dia-a-dia em atribuir notas aos estudantes, mas em observar e registrar seus percursos durante as aulas, a fim de analisar as possibilidades de aprendizagem de cada um e do grupo como um todo. Pode, dessa forma, planejar e replanejar os processos de ensino, bem como pode planejar as possibilidades de intervenção junto às aprendizagens de seus estudantes. (p. 30)

Enfatizam os autores, que se não houver uma mudança na concepção de educação, dificilmente a avaliação adquirirá uma perspectiva formativa. O primeiro movimento, portanto, não é modificar os instrumentos, mas os objetivos da avaliação, ou seja, “o importante não é a forma, mas a prática de uma concepção de avaliação que privilegia a aprendizagem”. (idem, p.31) 
A avaliação na progressão continuada possibilitaria a emergência de práticas avaliativas com finalidades formativas, respeitando-se o ritmo dos alunos, reorganizando tempos e espaços de aprendizagem, redefinindo a relação professor/aluno e família/escola. Nos depoimentos dos professores coordenadores pudemos identificar que o que vem ocorrendo é uma acomodação e adequação de práticas tradicionalmente já desenvolvidas nas escolas a realidade imposta pela progressão continuada, e não mudanças em direção à avaliação formativa.

\section{Destaque para a avaliação continuada e cotidiana}

Como uma mudança nas práticas avaliativas na perspectiva da progressão continuada os relatos dos entrevistados explicitaram a necessidade da avaliação não se restringir ao final do processo de ensino, mas ser inerente a ele. Podemos identificar a noção de que ensino e aprendizagem caminham juntos e que a avaliação deve permear esse processo, se traduzindo na necessidade de avaliar continuamente, ou seja, a todo o momento. Assumir a idéia de uma avaliação continuada, e, portanto, formativa, significa compartilhar de uma idéia de educação que procura adequar o ensino às necessidades de aprendizagem dos alunos, como afirmam Fernandes e Freitas:

Se entendermos que os estudantes aprendem de variadas formas, em tempos nem sempre tão homogêneos, a partir de diferentes vivências pessoais e experiências anteriores e, junto a isso, $s$ entendermos que o papel da escola deva ser o de incluir, de promover o crescimento, de desenvolver possibilidades para que os sujeitos realizem aprendizagens vida afora, de socializar experiências, de perpetuar e construir cultura, devemos entender a avaliação como promotora desses princípios, portanto, o seu papel não deve ser o de classificar e selecionar os estudantes, mas sim o de auxiliar os professores e estudantes a compreenderem de forma mais organizada seus processos de aprender e de ensinar. Essa perspectiva exige uma prática avaliativa que não deve ser concebida como algo distinto do processo de aprendizagem. (2008, p.21)

As práticas tradicionalmente desenvolvidas nas escolas tinham como principal instrumento de avaliação as provas, mensais e/ou bimestrais. Diante da necessidade de mudança da avaliação, a prova passou a ser entendida como em oposição a uma avaliação processual, contínua, formativa. Dessa forma, deixou de ser utilizada em muitas escolas, como revelado nos depoimentos coletados. 
Com o objetivo de avaliar continuamente, desenvolveu-se uma prática de utilização de uma variedade de instrumentos e de valorização de todas as atividades realizadas pelos alunos em sala de aula. No relato dos professores coordenadores, evidenciou-se que essas práticas não indicaram uma finalidade formativa no modo de se realizar esta avaliação contínua, pois se fundamentaram no registro quantitativo das atividades discentes com o intuito de atribuir uma nota ou conceito no final do bimestre.

Se, na prática, a avaliação contínua e cotidiana, que os entrevistados disseram fazer os professores, revelasse a realização de uma observação cuidadosa e objetiva, que promovesse intervenções, o mais cedo possível, para sanar as dificuldades de aprendizagem dos alunos e caracterizasse uma postura diferente das práticas tradicionais, nas quais a avaliação acontece em dia e hora marcados, poderíamos afirmar que houve uma mudança na avaliação caminhando para uma perspectiva formativa. Entretanto, não foi essa tendência explicitada nos depoimentos, mas sim a permanência de uma prática tradicional fundamentada em múltiplos instrumentos de avaliação.

Importa dizer que avaliar continuamente implica em lançar mão de uma variedade de instrumentos e não se restringir a momentos marcados, combinados entre o professor e a turma. Por outro lado, essa postura não elimina momentos específicos de aplicação de instrumentos que podem ser boas fontes de informação acerca da aprendizagem e das dificuldades dos estudantes. Portanto, a diversidade de instrumentos e momentos de avaliação é que permite ao professor coletar informações mais precisas e propor ações adequadas para cada dificuldade identificada, como indica Vianna:

A avaliação, particularmente a que é realizada em sala de aula, sob
responsabilidade do professor, é mais importante, sem dúvida, porque não se
restringe a um único instrumento, mas resulta, quase sempre, de muitos
outros tipos de fazeres, que englobam elementos qualitativos, incluindo entre
essas práticas as técnicas de observação. (2005, p. 29)

Sendo assim, concluímos que a avaliação contínua e cotidiana revelada na fala dos entrevistados como uma mudança nas práticas avaliativas impressas pela adoção do regime de progressão continuada, não caracteriza, efetivamente, uma mudança de concepção da avaliação, pois mantêm como principal função a atribuição de notas, constituindo-se, na prática, apenas na multiplicação de instrumentos de avaliação. No entanto, verificou-se uma mudança do ponto de vista dos discursos, o que potencialmente poderia a vir a ser o embrião 
de mudanças efetivas, não fossem as tensões entre as concepções divulgadas pela progressão continuada e pelo SARESP, o que se tratará adiante.

\section{Finalidade da avaliação: entre a cruz e a espada}

A necessidade de se ressignificar a avaliação da aprendizagem com a implantação do regime de progressão continuada pautou os diferentes discursos acerca dessa medida. Tanto a legislação educacional, que visou normatizar a implantação da progressão continuada, assim como o discurso teórico subjacente a esta medida enfatizavam a necessidade da avaliação assumir um papel formativo.

Como já indicamos, o papel formativo da avaliação vincula-se diretamente a sua finalidade. Na avaliação tradicional, que imperava na maioria das escolas, essa finalidade era a de atribuir notas que serviriam para decidir sobre a promoção ou reprovação dos estudantes no final do ano letivo e, de certa forma, condicionar o aluno ao estudo, pela necessidade de apresentação de um produto final, compatível com sua apreensão dos conteúdos apresentados pelo professor.

A progressão continuada restringiu a possibilidade de reprovação e, ao propor que a avaliação se tornasse formativa e não mais classificatória e excludente, dava outra finalidade para as práticas avaliativas. Entretanto, as notas continuaram a fazer parte das exigências do sistema de ensino, portanto, ao final de cada bimestre o professor deveria sintetizar o rendimento escolar do aluno por meio de uma nota ou conceito.

Ainda que a nota nesse contexto tenha uma função mais relacionada a um registro para informar o sistema de ensino e as famílias, além dos alunos e professores, sobre o rendimento escolar, pudemos identificar, nos depoimentos dados pelos entrevistados, que a finalidade da avaliação permaneceu, na maioria dos casos, atrelada às notas.

Essa vinculação, reforçada pelo próprio sistema de ensino, deve-se, em grande parte, a força da cultura escolar, que sempre teve as notas como elemento central das práticas escolares. Em 2007, a Secretaria de Educação, por meio da Resolução nº 61, uniformizou o processo de registro do rendimento escolar definindo um padrão numérico para toda a rede de 
ensino $^{27}$. Importa dizer que não houve nenhum debate sobre as implicações dessa mudança no sentido de que concepção de educação ela traz subjacente e como dialoga com a progressão continuada $^{28}$.

Compreendemos que a padronização dos registros quantitativos teve um papel muito mais burocrático do que pedagógico. Entretanto, ao definir que os registros serão feitos considerando uma escala de zero a dez, sem discutir as questões relativas ao significado das notas e como chegar a uma síntese numérica que procure traduzir o que o aluno sabe, o quanto aprendeu, pode reforçar a lógica de avaliar para atribuir notas. O relato a seguir procura ilustrar essa situação:

Eu trabalhei com nota, com número, com letras, mas acho que o correto é número mesmo. Quando você trabalha com A, B, C, D acaba sendo injusto com alguns alunos. Professor divide a média e o aluno deixou de fazer alguma atividade, ele está sendo prejudicado. Às vezes o aluno tem habilidade em todas as disciplinas. Vamos supor que o professor tenha dado 05 atividades para ele. Se ele perdeu duas e não fez a recuperação, se eu tirar a média por 05 ele estará sendo muito prejudicado. Talvez a secretaria tenha tomado essa atitude até por conta disso mesmo, pressionar o professor para ele recuperar o aluno. É fácil não entregou atividade, deixou de fazer duas, o professor fala fica com C comigo, ele não fez. Agora não, se ele tirar a média, o que vai acontecer, às vezes é um aluno excelente, mas se eu tirar a média e ele não fez alguma atividade, o professor vai repensar essa nota. È um aluno excelente, vai dar uma nota baixa para ele. Talvez até pensando no sentido de recuperação, de recuperar o aluno, é que a secretaria deu uma mexida nisso daí. Antes, eu mesmo como professor fui injusto com alguns alunos, não tenho vergonha de falar. Todo mundo que esteve em sala de aula foi injusto com algum aluno. Essa padronização melhorou. (PCIX)

De algum modo, algumas medidas tomadas pela Secretaria de Educação, como a descrita anteriormente, tendem a reforçar uma ênfase nas notas e não na aprendizagem. Essa ênfase manteve-se presente, mesmo após tantos anos de progressão continuada, pois, apesar das recomendações previstas na legislação e de muitos professores, conforme relato dos professores coordenadores, aderirem ao discurso da avaliação continuada, na prática mantém

\footnotetext{
27 Até essa ocasião o sistema de registro do rendimento escolar dos alunos era definido pelo Regimento Escolar. Cada escola decidia a melhor forma de síntese dos registros escolares acerca da avaliação, variava de escola para escola, mas girava em torno das notas numéricas ou dos conceitos, podendo ser A, B, C, D, E ou Plenamente Satisfatório (PS), Satisfatório (S), Não Satisfatório (NS), além de outras variações.

${ }^{28}$ Houve uma consulta disponibilizada no site da Secretaria de Educação para que os professores escolhessem a forma que considerassem mais adequada de registro. Entretanto, não houve um processo de discussão sobre o que representa esse registro e o que cada escolha significa, que concepção de educação e de avaliação estão em questão ao fazer determinada escolha.
} 
uma avaliação classificatória e se, em alguns anos ou séries do Ensino Fundamental, não podem reprovar, ainda permanece o desejo de fazê-lo. O relato a seguir é ilustrativo dessa situação:

Tem professor que quer chegar ao final do ano e falar que ele não sabe produzir texto e vai ser retido. Mas e o trabalho que foi feito durante o ano, tenho que trabalhar com ele, ler, ensinar. Para alguns é mais fácil reprovar, no ano seguinte ele faz de novo e aprende. (PCI)

Portanto, o que ficou evidente nos depoimentos dos professores coordenadores é que as mudanças processadas nas práticas avaliativas com o advento da progressão continuada não tiveram o alcance e a profundidade para transformá-las em direção a concepção e práticas formativas.

\section{Tendência a práticas avaliativas mais flexíveis}

Se por um lado as práticas avaliativas desenvolvidas no interior das escolas onde atuam os entrevistados não revelaram uma transformação no sentido evocado pela progressão continuada, de outro, também não podemos afirmar que avanços na tentativa de práticas mais adequadas não se processaram.

Os relatos dos entrevistados evidenciaram uma tendência das práticas avaliativas se tornarem mais flexíveis. Essa flexibilidade foi descrita pelos entrevistados por atitudes reveladas nas práticas escolares cotidianas que indicam uma maior disponibilidade dos professores em atenderem as dificuldades dos alunos, dedicando um maior tempo e atenção aos problemas de aprendizagem. Outro momento em que é perceptível essa mudança na postura dos professores frente às dificuldades dos alunos, segundo alguns relatos, são os conselhos de classe que ocorrem durante o ano, nos quais, alguns professores, procuram efetivamente refletir sobre a conduta dos alunos em relação as suas aulas e a dos demais colegas, principalmente no Ciclo II.

Como problematizamos anteriormente, essa flexibilidade talvez não se traduza no cotidiano escolar em ações formativas na perspectiva da avaliação. Ações de planejamento e replanejamento, encaminhamentos para recuperação contínua ou paralela podem evidenciar avanços em relação às práticas tradicionais. Entretanto, estudos e análise mais detalhados do cotidiano escolar e com foco no professor poderiam revelar se essas práticas auxiliam os 
alunos na superação de suas dificuldades ou apenas representam situações centradas apenas na melhoria das notas.

A flexibilidade apresentada por alguns professores, o esforço sincero no sentido de almejar uma avaliação formativa e o anseio de tentar compreender a progressão continuada devem servir como ponto de partida para os gestores do sistema de ensino e demais responsáveis por desencadear a formação em serviço na busca de práticas escolares e avaliativas que garantam a aprendizagem de todos os alunos e valorizem o que vem sendo feito, mesmo com poucos recursos e orientação, na busca da melhoria da qualidade da educação.

\section{SARESP e as implicações na avaliação escolar}

Enquanto a progressão continuada foi compreendida e assimilada por muitos docentes como promoção automática e permanecendo um desconforto e descontentamento em relação a esta medida, o SARESP é identificado, na fala dos entrevistados, como compreendido e assimilado pelos professores.

Essa tendência de aceitação do SARESP talvez se deva às orientações e aos subsídios que, se não são suficientes, ofereceram apoio às escolas e seus profissionais. Nas primeiras edições, o SARESP foi visto com desconfiança pelos professores, de acordo com o que disseram os entrevistados, atualmente a medida é compreendida e assimilada nas escolas, conforme relatado por eles.

Uma hipótese que lançamos acerca de uma maior aceitação do SARESP em relação à progressão continuada são as implicações dessa medida para as escolas e professores, tais como a vinculação ao pagamento de bônus para os profissionais da escola, como já vem ocorrendo na rede estadual paulista e se intensificado na atual gestão, atrelando o resultado do SARESP ao cálculo do IDESP.

Outro fator que pode ter contribuído para uma maior aceitação do SARESP é certa identificação que os professores possivelmente têm como o modelo de prova aplicado no SARESP. Sabemos que a escola tradicionalmente valoriza o momento de prova, com seu ritual de organização, aplicação, correção e controle. De alguma forma, o SARESP retoma 
esse procedimento o que, provavelmente, veio alentar as perspectivas dos professores em relação a um retorno das práticas avaliativas usualmente utilizadas, ou seja, a aplicação de provas.

\section{Aplicação dos simulados e avaliação unificada}

Nos depoimentos dos professores coordenadores, em relação às mudanças nas práticas avaliativas promovidas pela adoção da progressão continuada, foi evidenciado que houve certo abandono das provas enquanto instrumentos de avaliação, como problematizado anteriormente.

Com o advento do SARESP, os professores, segundo os professores coordenadores, identificaram duas dificuldades: os alunos não iam bem no SARESP por não saberem como responder aquele modelo de prova, ou seja, testes; e não tinham motivação para responder a prova, pois não compreendiam os motivos de fazerem uma avaliação cuja nota não traria consequências, ao menos identificáveis, no rendimento escolar.

Objetivando enfrentar a primeira dificuldade, os professores coordenadores relataram que o SARESP passou a servir de modelo para a elaboração de outras provas na escola. Nas primeiras aplicações o que se procurava fazer era utilizar a prova do SARESP para orientar os alunos em como respondê-la, como preencher o gabarito e como lidar com as dúvidas e o tempo de realização da prova.

A medida que essa estratégia foi se revelando eficaz, por um lado, e insuficiente, por outro, pois dava conta de aspectos procedimentais, mas não relativos aos conhecimentos necessários para responder aos testes, originou, em alguns casos, a realização de uma avaliação unificada, organizada por todos os professores, possibilitando, nesses momentos de elaboração, a discussão em torno do que se está ensinando, das dificuldades apresentadas pelos alunos, permitindo a troca de experiências e conhecimentos entre os professores.

Como já indicamos anteriormente, a progressão continuada provocou, de um modo geral, uma diminuição no uso da prova como instrumento de avaliação. Entretanto, o advento do SARESP impulsionou a retomada das provas no contexto das práticas avaliativas na escola. Dessa forma, pelo relatado, o SARESP passou a nortear procedimentos de avaliação da aprendizagem. A princípio, a aplicação de provas, seguindo o modelo do SARESP, 
objetivava apenas preparar os alunos para o dia de aplicação da avaliação externa. Com o tempo, as provas passaram a servir para avaliar o ensino planejado e desenvolvido pelos professores no transcorrer do ano letivo. Nesse sentido, podemos dizer que o SARESP vem forjando uma prática avaliativa seguindo seu modelo, além de delimitar os conteúdos a serem ensinados e avaliados.

Com relação aos conteúdos escolares, vale ressaltar que eles passaram a ser pautados pelo SARESP. Muitos professores, a partir dos seus resultados, ficaram preocupados em ensinar o que a avaliação exige. Em muitos depoimentos, ficou explicitado que havia conteúdos que não vinham sendo ensinados na escola. Um exemplo clássico, nesse sentido, seria o ensino da geometria que, na maioria das vezes, ficava em segundo plano; com o SARESP os professores de Matemática passaram a dar mais atenção a esse conteúdo.

Oliveira e Pacheco (2003), ao analisarem a relação que se estabelece entre o currículo e a avaliação escolar nos alertam que:

Se o que se pretende é considerar os conhecimentos dos alunos como redes
tecidas através de processos de aprendizagem singulares, múltiplos e
imprevisíveis, na medida em que cada aluno incorpora as novas informações
às suas próprias redes de modo diferente dos demais, é necessário que se
procure desenvolver formas e instrumentos de avaliação compatíveis com
essa pluralidade de pessoas, de saberes e de processos de aprendizagem. Por
esse motivo, faz-se necessário que a reflexão em torno das questões
curriculares e as tentativas de mudança dos mecanismos e instrumentos
clássicos de avaliação caminhem juntas. Ou seja, precisamos nos perguntar
sobre a possibilidade de produzir instrumentos de avaliação que contemplem
o que efetivamente se faz e se considera importante nas salas de aula, não a
partir apenas de listagens de conteúdos presentes nos livros didáticos, em
planejamentos de aula e de curso ou em propostas oficiais. (125-126)

A observação feita pelos autores já anunciava uma preocupação da avaliação externa induzir práticas avaliativas, assim como definir conteúdos curriculares, em detrimento das especificidades dos alunos, das turmas e das escolas, produzindo uma padronização que desconsidera as características e identidade das comunidades escolares, gerando um ensino desconectado da realidade escolar.

Além de servir de modelo para o desenvolvimento de procedimentos avaliativos no cotidiano escolar, na tentativa de gerar um comprometimento dos alunos com a resolução do SARESP, algumas escolas, de acordo com o que foi relatado, passaram a atribuir notas para os alunos e a utilizarem essas notas na composição da média bimestral. Evidencia-se, assim, uma perspectiva de valorização da nota, o que reforçaria, na lógica escolar, a permanência do 
estímulo externo aos estudos e não pela adesão dos estudantes aos procedimentos e conteúdos escolares.

Vale ressaltar que, nos depoimentos, essa situação de atribuição de notas ao SARESP como motivação para que o aluno o leve a sério não foi unânime, havendo relatos de escolas que buscaram conscientizar os estudantes da importância dessa avaliação e como, indiretamente, ela os afeta em sua aprendizagem, procurando explicitar quais são seus os objetivos. Ao buscar informações sobre o SARESP para poder orientar os estudantes, os professores envolvidos nessa ação passam a compreender e perceber as possibilidades que são abertas ao considerarmos os resultados das políticas educacionais, podendo ter mais clareza sobre elas.

Enquanto a progressão continuada, por sua natureza e forma de implantação, desestabilizou as práticas tradicionais de avaliação realizadas pelas escolas, o SARESP, pelo que identificamos nos depoimentos dos entrevistados, vem desempenhando um papel inverso, de restabelecer algumas práticas avaliativas no cotidiano escolar, como a aplicação de provas. Devemos considerar, ainda, as finalidades da aplicação dessas provas que, se por um lado, servem para preparar os alunos para a prova do SARESP, de outro podem servir para fortalecer uma perspectiva tradicional de avaliação, reforçando a lógica da atribuição de notas e o papel do professor como centro do processo de avaliação.

Se antes, a função primordial da prova era a atribuição de notas e a futura decisão sobre a promoção ou reprovação dos estudantes, no contexto da avaliação externa ela se apresenta como instrumento que orienta o aluno a responder determinado tipo de prova e, em relação ao professor, se o que ele propôs desenvolver com seus alunos está sendo alcançado.

O desempenho nessas provas tem auxiliado os professores a refletirem sobre as dificuldades dos alunos e desenvolverem propostas para a superação dessas dificuldades. É também com base no resultado do SARESP ou das provas nele inspiradas que são identificados os alunos que necessitam de processos de recuperação paralela e reforço. Estaria, dessa forma, a avaliação externa induzindo a uma prática avaliativa formativa?

A resposta a essa questão implicaria um estudo aprofundado que possibilitasse compreender como se processam as práticas avaliativas cotidianas, pois, pelo que foi dito pelos professores coordenadores, não é possível dar uma resposta conclusiva. 
Mas, se refletirmos sobre o que significa a avaliação formativa e sua estreita relação com as dificuldades de aprendizagem dos alunos e que essas dificuldades vinculam-se aos processos individuais de formação, pode-se dizer que as provas revividas com o SARESP não seriam um avanço na direção da avaliação formativa. Neste sentido, Perrenoud (2004) afirma que:

A avaliação formativa, como instrumento de regulação da aprendizagem e do ensino, nada mais é do que um componente de uma pedagogia diferenciada. Para colocar cada aluno o mais frequentemente possível nas situações didáticas mais fecundas para ele, importa que o professor saiba o que o aluno compreendeu, no que ele tropeça, como aprende, o que o auxilia ou o que perturba, interessa-o ou o aborrece etc. É a função da avaliação formativa: permitir ao professor saber bastante sobre tudo isso para otimizar as situações de aprendizagem propostas a cada aluno. (p. 115)

Em alguns depoimentos também ficou evidente que escolas, objetivando a seriedade e envolvimento dos alunos na resolução dos testes do SARESP, desenvolveram procedimentos de orientação e conscientização dos alunos da importância da avaliação externa. Esse movimento de conscientização foi explicitado na fala dos professores coordenadores em relação ao SARESP, mas não foi relatado o mesmo em relação à progressão continuada.

Nesse sentido, podemos perceber que o SARESP incide tanto na retomada de mecanismos de convencimento e controle dos alunos, quanto em processos de informação e conscientização. Favorecer uma postura mais conservadora ou democrática no interior da escola no tocante as práticas avaliativas não depende do SARESP enquanto medida política, mas sim de como os professores e demais profissionais que atuam na escola se apropriam, analisam e decidem os encaminhamentos a serem tomados. Se o SARESP remete a práticas avaliativas tradicionais, induzindo a manutenção de uma avaliação mais conservadora, isso se deve ao fato dos professores, mesmo abolindo algumas práticas tradicionais, ainda manterem uma visão conservadora e desejarem o retorno da reprovação em todas as séries do Ensino Fundamental.

\section{SARESP: orientando o currículo e as práticas escolares}

Uma importante revelação em relação ao SARESP foi de que vem sendo utilizado no planejamento escolar. O resultado da escola e das turmas é analisado nos momentos de 
planejamento e replanejamento e orientam o trabalho escolar, na definição de habilidades, competências e conteúdos a serem ensinados.

De certo modo, esse uso dos resultados era esperado pelos estudiosos da avaliação, como nos informa Vianna:

Os resultados das avaliações não devem ser usados única e exclusivamente para traduzir um certo desempenho escolar. A sua utilização implica em servir de forma positiva na definição de novas políticas públicas, de projetos de implantação e modificação de currículos, de programas de formação continuada dos docentes e, de maneira decisiva, na definição de elementos para a tomada de decisões que visem a provocar um impacto, ou seja, mudanças no pensar e no agir dos integrantes do sistema (2005, p. 17).

O que nos cabe refletir a partir das evidências fornecidas por esta pesquisa é se os usos feitos dos resultados do SARESP tanto pelas escolas, assim como pelos gestores do sistema, servem, como afirma Vianna, "de forma positiva" na busca da melhoria da qualidade do ensino e na garantia de aprendizagem a todos os alunos.

Nos depoimentos dos professores coordenadores fica patente a influência do SARESP no currículo e no desenvolvimento de estratégias de ensino. Conforme informações prestadas pelos entrevistados, os professores levam as provas do SARESP para a sala de aula, aplicam os exercícios, elaboram atividades seguindo esse modelo, corrigem e analisam as redações seguindo a estrutura de análise e correção propostas pelo SARESP, incluem ou eliminam conteúdos do planejamento de ensino e de aulas conforme o que "cai" no SARESP.

Além dos elementos já enunciados, devemos às diversas edições do SARESP a inserção, nas discussões pedagógicas, do destaque e da importância das habilidades e competências. Também a apropriação, com maior frequência, de um vocabulário oriundo da avaliação externa, tais como índices de proficiência, matriz de referência etc. Os resultados, utilizados como diagnóstico, orientam o planejamento, o replanejamento e definem os alunos que necessitam participar de processos de recuperação.

Podemos afirmar, sem receio, que, pelo que foi evidenciado nos depoimentos, o SARESP está presente no cotidiano escolar, influenciado práticas, definindo metas, estabelecendo rumos, orientando o trabalho pedagógico. Um dos objetivos anunciados pela Secretaria de Educação nos primórdios dessa avaliação seria o de "criar uma cultura avaliativa" na rede estadual. Estaria este objetivo sendo atingido? Que cultura estaria sendo forjada a partir dessa avaliação externa? 
Vianna ao abordar essa questão de uma cultura da avaliação afirma que:

A expressão "cultura da avaliação" integra, atualmente, a constelação de palavras técnicas no âmbito da comunidade educacional e aos poucos vai se tornando verdadeiro lugar comum, quase que simples figura de retórica; no entanto, é preciso que essa expressão se liberte do seu caráter de mero truísmo e se transforme numa efetiva política de ação. $(2005$, p.16)

Talvez estejamos assistindo no estado de São Paulo a transformação dessa expressão "numa efetiva política de ação". Devemos nos indagar, entretanto, que política de ação está se delineando nas escolas da rede estadual e quem são os atores dessa ação? As repostas dadas pelos entrevistados iluminam algumas pistas no sentido de refletir sobre esse tema.

Percebemos, pelos relatos dos professores coordenadores, que os professores se preocupam com o SARESP, que buscam informações sobre ele, que tentam desenvolver ações baseadas nos seus resultados, que a Secretaria de Educação procura orientar e propor encaminhamentos em relação à avaliação externa. Por outro lado, com relação à progressão continuada não evidenciamos a mesma situação, podendo dizer que, em alguns casos, ocorre o contrário, levando a uma rejeição a essa medida.

Entendemos que o SARESP vem se constituindo na principal política da Secretaria de Educação do Estado de São Paulo, com maior direcionamento sobre as ações que ele deve desencadear nas escolas. A atual gestão explicita a importância da avaliação externa e tem tomado medidas que visam fortalecer essa modalidade de avaliação no interior das escolas.

A ênfase dada aos gestores do sistema e da escola, como supervisores, diretores e professores coordenadores, à implantação de um currículo unificado a partir de 2008, vinculado ao SARESP, à produção de materiais de apoio com o planejamento de aulas para aplicação pelos professores, são indícios mais do que suficientes do dirigismo implementado a partir dos resultados obtidos na avaliação externa.

A política meritocrática que se instaura e a criação de metas que a escola deve atingir anualmente, ou seja, o Índice de Desenvolvimento da Educação de São Paulo, tendem a colocar o SARESP no centro das ações do sistema de ensino e das escolas. Serão positivas essas mudanças que se anunciam no horizonte da educação paulista? Quais as consequências desse direcionamento para a autonomia do trabalho pedagógico, da democratização da gestão e do ensino? Que consequências trará essa evidente centralidade da avaliação externa para a tão fragilizada progressão continuada, para a organização do ensino em ciclos e para a avaliação formativa? 
De certo modo, alguns pesquisadores, partindo de análises de outros contextos inclusive, nos alertam que:

Há igualmente que repensar as formas de avaliação institucional de tal modo que as alternativas não sejam apenas aceitar com inevitável que esta avaliação se inscreva ou na lógica restrita do Estado ou na lógica restrita do mercado. Uma alternativa mais avançada em termos políticos e educacionais implica equacionar outras possibilidades que pressupunham que não apenas um maior respeito pelos professores como profissionais, como também um papel mais ativo e participativo dos outros atores escolares e da comunidade. (AFONSO, 2003, p.51).

Sendo assim, é da escola que devem emergir as respostas das perguntas anteriormente levantadas. Como irão reagir os profissionais que atuam no interior das escolas às diretrizes propostas pela política educacional? Obviamente que um embate de forças e interesses é que fará emergir das escolas uma nova realidade. Nova, no sentido de que a avaliação externa não havia atingido um grau de influência tão grande, mas não necessariamente democrática, inclusiva e com qualidade. A influência do SARESP e a necessidade de melhoria do rendimento escolar dos alunos podem gerar um ensino preocupado em atingir as metas previstas pela Secretaria de Educação, promovendo práticas escolares que não levem em consideração as especificidades dos estudantes, diferentes ritmos e trajetórias, definindo as necessidades unicamente por meio do SARESP.

A avaliação externa tem como um dos seus objetivos servir como referência para o sistema, para as escolas e para a sociedade, verificando se o que se espera que minimamente seja garantido aos usuários da escola pública está sendo aprendido. O que temos percebido pelos resultados divulgados ano após ano, seja no SAEB, SARESP ou outra avaliação com objetivos semelhantes, é que a escola pública não tem assegurado nem o mínimo esperado para a maioria dos estudantes. Talvez os baixos índices e a repercussão que os resultados que a avaliação externa tem na mídia possam ser identificados como fatores que expliquem uma aceitação e utilização dos resultados pelos professores, como constamos nessa pesquisa.

Percebemos que há uma tendência do SARESP ser utilizado cada vez mais como norteador do currículo e do planejamento escolar. Isso se deve, em parte, pelo enfraquecimento da política de ciclos e progressão continuada. Se houvesse um fortalecimento e implementação de medidas que garantissem condições para a sua efetivação, tais como um currículo flexível, voltado para as necessidades dos alunos, diminuição do número de alunos em sala de aula, orientação e formação para os professores em torno da lógica de organização do ensino em ciclos; provavelmente, o SARESP não encontraria terreno 
tão fértil para se tornar o centro do trabalho pedagógico, promovendo implicações no planejamento e na avaliação feita pelos professores.

O que os depoimentos nos possibilitam dizer a respeito das impressões que o SARESP tem produzido é que as mudanças que vêm sendo empreendidas pela Secretaria da Educação são bem vistas, de modo geral, pelos professores. Eles vêem em certas ações, como a implantação do currículo oficial, segurança e apoio no desenvolvimento da docência e também consideram que traz maior clareza e objetividade ao SARESP.

O que fica claro é que o SARESP vem incidindo, de modo crescente, na organização do trabalho escolar e nas práticas avaliativas, promovendo mudanças, acomodando práticas e servindo de norte para professores e alunos.

Deveria uma avaliação externa incidir de forma tão acentuada na organização do trabalho pedagógico? Nos relatos dos professores coordenadores acerca da implantação do SARESP, nos primeiros anos de vigência, foi explicitado certo temor em relação a ele, preocupação com o uso dos resultados no sentido de gerar punição as escolas e professores que o rendimento escolar dos alunos fosse considerado inadequado.

Lembremos que em 2001 o resultado do SARESP foi utilizado para classificar as escolas em melhores e piores, fazendo uso para tanto de uma escala de cores. Além disso, premiou as melhores e impingiu processos de formação continuada aos profissionais das escolas consideradas piores. Por fim, foi utilizado para definir sobre a continuidade dos estudos dos alunos de um ciclo a outro, chamando para si uma decisão que deveria ser refletida e tomada pelos professores e a equipe de gestão da escola.

Mais de uma década depois, outro olhar recai sobre o SARESP. É aceito, passa a servir de referência para planejar, avaliar e norteia a estruturação do currículo oficial. Seria a vinculação ao bônus pago aos professores e demais profissionais da Secretaria de Educação explicação suficiente para uma visão mais favorável em relação à avaliação externa? Essa preocupação dos professores, evidenciada nessa pesquisa, em utilizar os resultados do SARESP procurando melhorar o desempenho dos alunos levará a melhoria da qualidade do ensino?

Se considerarmos o potencial organizador das práticas escolares que o SARESP tem evidenciado, poderíamos dizer que a trajetória da avaliação externa em São Paulo foi a de ir buscando uma acomodação e assimilação dessa política. Em torno do SARESP estaria emergindo uma nova escola? Devido às implicações do SARESP, evidenciadas nessa 
pesquisa, poderíamos dizer que a escola, ao invés de se assumir características democráticas e inclusivas, vem se tornando conservadora, pois tem promovido práticas escolares e avaliativas fundamentadas em princípios e concepções tradicionais que sempre caracterizaram a avaliação escolar. 


\section{CONSIDERAÇÕES FINAIS}

Esta pesquisa objetivou apreender as implicações da progressão continuada e do SARESP na avaliação escolar. Para tanto, procuramos identificar, nas respostas dadas em questionários e entrevistas realizadas com professores coordenadores, tensões, dilemas e tendências que estão se delineando nas escolas, induzidas por essas medidas.

Podemos afirmar que a progressão continuada promoveu alterações na avaliação escolar. Evidenciou-se, nos depoimentos dos professores coordenadores, que a avaliação após a progressão continuada, não permaneceu da mesma maneira.

Uma das mudanças identificadas na avaliação em função da progressão continuada deu-se no plano do discurso dos profissionais da educação. Segundo o que relataram os professores coordenadores, os professores se apropriaram, em sua maioria, do discurso que preconiza uma avaliação contínua, processual, formativa. Que os professores procuram, cada vez mais, diversificar os instrumentos de avaliação, inclusive sendo a prova "banida", por muitos professores, das práticas avaliativas por ser considerada como inadequada no contexto da progressão continuada.

Também a avaliação perdeu seu caráter pontual, tornando-se contínua, avaliando-se a todo instante. Foi destacado também seu caráter diagnóstico, servindo como referência para o desenvolvimento do trabalho escolar.

Identificamos, entretanto, a existência de um tensionamento entre o discurso e a prática avaliativa. Ao falarem sobre as práticas avaliativas que a progressão continuada induziu no contexto escolar e ao demonstrarem, com exemplos concretos do fazer pedagógico, os procedimentos que são desenvolvidos pelos professores, não encontramos evidências de práticas formativas, apenas adequações às noções prescritas pela progressão continuada, permanecendo uma concepção tradicional de avaliação.

Nestes anos em que esta medida encontra-se em vigor, disseminaram-se na rede estadual discursos que preconizam a avaliação continuada, processual, que ela seja constante e assuma uma perspectiva formativa. Entretanto, revela-se nesta pesquisa, que, no discurso, as concepções e práticas mencionadas não são mais as mesmas; no fazer pedagógico elas se revelam como formas de acomodação, adequação e manutenção das práticas avaliativas 
tradicionais, pois a finalidade da avaliação permanece a mesma. Por que a progressão continuada não provocou uma mudança nos princípios que fundamentam concepções e práticas avaliativas?

Não é difícil dizer quais seriam as causas dessa situação. Algumas delas as pesquisas acadêmicas já apontavam, tais como: a forma de implantação da progressão continuada desconsiderando a realidade escolar; a ausência de participação dos professores nos encaminhamentos e discussões para a adoção da medida; a falta de condições objetivas de trabalho que reduzissem o número de alunos e favorecessem a formação de grupos diferenciados, de acordo com o desenvolvimento de cada aluno; a dificuldade em promover a individuação de trajetórias que atendam as especificidades de diferentes ritmos de aprendizagem.

Uma causa que ficou patente nos relatos dos entrevistados foi a ausência de orientações e formação no sentido de compreender o que é a progressão continuada e de como trabalhar e avaliar nesse contexto. Alguns coordenadores disseram que somente passaram a compreender melhor a progressão continuada quando foram trabalhar na coordenação, o que pode ser atribuído ao fato de receberem mais orientações nessa função do que como professores em sala de aula.

Mas, devemos considerar que somente a falta de condições necessárias à implantação dessa política não explicaria a dificuldade em transformar a educação e atingir os objetivos de melhoria da qualidade do ensino e de democratização da escola. A transformação da escola tradicional, classificatória e excludente, para uma escola democrática e inclusiva, na qual a avaliação assuma seu caráter formativo, também passa pelo desejo dos profissionais. Os valores e concepções de muitos profissionais da educação, em especial os professores, ainda se assentam na lógica da escola que gera competição, que individualiza, que premia e que pune. Se houvessem condições ideais de trabalho, salários adequados e condizentes com as necessidades dos professores, seria suficiente para provocar uma mudança na lógica da avaliação?

Acreditamos que os aspectos mencionados são essenciais para criar condições para o bom trabalho docente e favorecer a aprendizagem de todos os alunos. Mas, também é necessário rever crenças e valores arraigados na forma de organização do trabalho pedagógico, concepções e práticas avaliativas. Identificamos, nos relatos dos professores 
coordenadores, que muitos professores gostariam de poder reprovar em todos os anos do Ensino Fundamental.

O que queremos dizer com isso é que o professor não é o único responsável pela transformação da escola, mas suas concepções e valores influenciam quando se pretende promover alguma mudança. Sem sua adesão, as mudanças serão muito mais difíceis, se não praticamente impossíveis, de se efetivarem na prática escolar.

Uma das críticas feitas à implantação da progressão continuada, identificada em inúmeras pesquisas, como indicado no primeiro capítulo deste estudo, diz respeito à ausência de participação dos professores na formulação e implantação das políticas educacionais. Se a adesão dos professores é essencial para a concretização das políticas, deveria partir dos próprios gestores do sistema de ensino o diálogo com os profissionais da rede.

O que concluímos é que a progressão continuada traduziu-se em algo incômodo para os professores. Eles ainda encontram muita dificuldade em entendê-la e sentem que os alunos não se dedicam como antigamente, por saberem que poderão reprovar somente no final de cada ciclo. Outros relatos revelam que também existe o esforço de alguns professores em entender e promover mudanças em função da progressão continuada.

Também foram objetivos deste estudo identificar e analisar, na opinião dos professores coordenadores, eventuais repercussões do SARESP na avaliação escolar. De acordo com os relatos analisados o SARESP vem adquirindo uma maior repercussão no trabalho pedagógico do que a progressão continuada.

Alguns elementos que permitiram chegar a essa conclusão foram evidenciados nos depoimentos dos professores coordenadores como: utilização dos resultados do SARESP no planejamento escolar; a aplicação de simulados e provas unificadas que seguem o modelo do SARESP; a preocupação de muitos professores em trabalhar de acordo com as habilidades, competências e conteúdos solicitados no SARESP para que os alunos estejam preparados para serem avaliados. Outros elementos, não necessariamente explicitados nas opiniões dos entrevistados, podem ser arrolados como o bônus, o posicionamento das escolas nas classificações que são feitas, a preocupação com o desempenho satisfatório dos alunos, pois dele também decorre a imagem do bom professor.

Nos depoimentos, os entrevistados demonstraram que os professores aceitam o SARESP com certa tranqüilidade e buscam compreender seus mecanismos e suas cobranças 
em relação ao ensino. A partir dos resultados do SARESP os professores orientam os planos de ensino, procurando atender os conteúdos da prova que não foram contemplados anteriormente, procuram identificar as habilidades e competências que os alunos apresentaram maiores dificuldades e estruturam suas práticas pedagógicas no sentido de contemplá-las. Além desses exemplos, explicitados pelos professores coordenadores, adotam o modelo de instrumento proposto pelo SARESP, chegando ao requinte de aplicarem provas seguindo os mesmos procedimentos do dia do SARESP, pois dessa forma os alunos estarão mais bem preparados para responderem a prova.

O SARESP vem repercutindo sobre a avaliação escolar, na medida em que foi capaz que restaurar a prova como instrumento de avaliação e de devolver a suposta motivação perdida pelos alunos devido à implantação da progressão continuada. Também foi capaz de mobilizar os professores no sentido de conscientizarem os estudantes da importância de "levarem a sério" o SARESP, pois assim seu desempenho seria mais adequado, demonstrando com maior clareza as dificuldades dos alunos e não o descaso e displicência ao responderem a essa avaliação.

Pelos depoimentos dos professores coordenadores o SARESP vem se constituindo em "bússola" para o trabalho escolar, orientando práticas, redefinindo o currículo e balizando as avaliações internas, feitas pelos professores.

Podemos, portanto, dizer que os professores coordenadores entrevistados explicitaram a utilização dos resultados do SARESP e as repercussões desses resultados para as práticas avaliativas e o trabalho pedagógico. Nesse sentido, evidencia-se uma tendência de centralidade do SARESP na organização do trabalho escolar.

Se por um lado a progressão continuada não tem impactado no sentido de promover práticas avaliativas mais comprometidas com a aprendizagem dos alunos, assumindo um discurso e uma prática formativos, de outro se abre espaço que para que o SARESP ocupe o vácuo criado pela progressão continuada, instituindo e legitimando práticas arraigadas na cultura escolar, que tenderiam a orientar a avaliação da aprendizagem no interior da escola.

No início deste estudo apresentamos a problematização feita por Sousa e Barretto quanto às lógicas conflitantes entre a concepção de avaliação inerente à progressão continuada e a lógica da avaliação externa. Retomando essa idéia, enquanto a progressão continuada enfatiza uma concepção de avaliação formativa, a avaliação externa tem seu foco 
no desempenho dos estudantes em testes padronizados. A tensão entre esses dois modelos de avaliação estaria em como as escolas atenderiam as demandas de uma educação que contempla as diferenças de aprendizagem e visa o sucesso de todos os alunos, por um lado, e de outro, que atendam as exigências do sistema de ensino, explicitadas na avaliação externa.

De alguma forma, os depoimentos dos professores coordenadores permitem que lancemos algumas luzes acerca da tensão revelada pelas autoras. A aceitação do SARESP pelos professores e certa rejeição em relação a progressão continuada, a capacidade de mobilizar o planejamento e de induzir a escolha de conteúdos curriculares, além de outros aspectos anteriormente apresentados neste estudo, tendem a mostrar o predomínio do SARESP enquanto modelo de avaliação.

Os dados coletados nesta pesquisa revelam que a tensão que poderia ser criada pelos dois modelos de avaliação não tem a força que se esperava. A tendência é que as escolas optem por perseguir as metas estabelecidas pela avaliação externa, em detrimento dos resultados da avaliação feita em seu interior. Além disso, essa tensão se fortaleceria e produziria embates na decisão dos rumos a seguir se a noção de avaliação preconizada pela progressão continuada tivesse encontrado solo mais fértil.

Os resultados que vêm sendo indicados pelas avaliações externas, que se propõem a avaliar o desempenho dos alunos naquilo que é essencial que sejam capazes de fazer, revelam que a escola não tem conseguido atingir nem o mínimo esperado pelos sistemas, donde o impacto negativo dos resultados ao serem divulgados recaírem sobre as escolas como uma "bomba". Aliás, essa expressão "bomba", foi utilizada durante muito tempo nas escolas para designar a reprovação dos alunos. Portanto, podemos dizer a que a educação pública tem levado "bomba" nos exames a que tem se submetido.

O SARESP, ao revelar seus resultados, indica que a escola não tem atingido a expectativa mínima. Os professores, ao identificarem essas lacunas na aprendizagem dos alunos procuram atender ao solicitado na prova. Se por um lado o SARESP identifica que a escola não está conseguindo atender o mínimo esperado, por outro tem sido capaz de fazer com que as escolas busquem atender esse mínimo, o que leva a centralidade que ele vem adquirindo na orientação do trabalho escolar.

Seria o fracasso escolar responsável por fazer do SARESP um mecanismo central e forte na organização da política educacional de São Paulo? 
A tendência que identificamos neste estudo em relação às concepções e práticas avaliativas desenvolvidas no interior das escolas é de ser orientada por uma perspectiva de avaliação que encontra no SARESP um modelo a seguir. Portanto, como indicamos anteriormente, esse modelo gera o fortalecimento de práticas mais tradicionais, de uma avaliação que não leva em conta as diferenças e que promova práticas de ensino menos individualizadas e mais padronizadas.

A centralidade da finalidade da avaliação deslocou-se, em certa medida, da decisão sobre a aprovação/reprovação, para o SARESP. Essa situação revela ser, atualmente, o SARESP o mais potente indutor e implementador de políticas educacionais no estado de São Paulo.

A importância que o SARESP está adquirindo promove novas indagações, tais como: que currículo o SARESP está induzindo nas escolas e qual currículo decorre, na prática, do SARESP? Ao utilizarem os resultados do SARESP como elementos centrais no planejamento escolar, não estariam às escolas estruturando o currículo pelo desempenho dos alunos em uma única prova? E o discurso sobre a avaliação formativa, que lugar ele ocupa no contexto de uma política educacional centrada na avaliação externa? Que reflexões e reações estão sendo desencadeadas no interior das escolas no sentido de criticar a política educacional e repensar as questões da autonomia escolar? E a gestão? Podemos falar hoje em gestão democrática quando as decisões são definidas pelos resultados obtidos na avaliação externa e não pelas necessidades identificadas no interior da escola e no seu fazer cotidiano?

É inegável o significado das avaliações externas para a gestão dos sistemas de ensino, para a definição de políticas que priorizem as necessidades das escolas para que garantam a aprendizagem de todos os alunos. Também seus resultados podem ser úteis para as escolas repensarem práticas, identificarem lacunas e organizarem suas ações. Não nos posicionamos aqui contrários à avaliação externa, mas problematizamos a crescente influência na organização do trabalho escolar e na uniformização dos currículos, dificultando o trabalho pedagógico no sentido de promoção da igualdade e de proporcionar condições para que todos permaneçam e aprendam na escola.

Acreditamos que o caminho para evitar uma supremacia do SARESP na definição das políticas públicas e na organização do trabalho escolar ainda se encontra na perspectiva da progressão continuada, da escola organizada em ciclos e da avaliação formativa. Apesar de 
revelarmos neste estudo uma fragilidade dessa medida, principalmente em relação ao SARESP. Nela reside o potencial de transformação do ensino e de garantia da aprendizagem.

O sentido que tanto a progressão continuada quanto, mais possivelmente, o SARESP está imprimindo no trabalho pedagógico, não indica haver o fortalecimento de uma escola autônoma, democrática, inclusiva, que construa sua proposta pedagógica e se oriente pelas avaliações externas como uma forma de identificar se seus alunos têm o desempenho esperado. Hoje, podemos concluir que das duas medidas é o SARESP que tem favorecido o controle das escolas pelos gestores do sistema de ensino. Portanto, o SARESP é o instrumento, por meio do qual, essa gestão se processa.

O cenário que estamos procurando emoldurar contará, ainda, com elementos que estão se delineando e que tenderão a provocar novas tensões. Estamos falando da meritocracia e da avaliação dos docentes. A premiação dos profissionais pela melhoria nos índices de desempenho e a avaliação dos docentes podem gerar estímulos para a valorização dos professores e melhorar a qualidade do ensino. Por outro lado, podem gerar competição e exclusão. As ações que vêm sendo desencadeadas pela Secretaria de Educação confirmam a tendência de um maior controle das escolas por parte dos órgãos centrais e o SARESP tem se constituído no principal instrumento para a realização desse controle.

A emergência de pesquisas que iluminem o horizonte que vislumbramos neste estudo é necessária para que possam indicar os caminhos que a educação paulista irá trilhar. A tendência que pudemos identificar é o fortalecimento da avaliação externa e a crescente implementação da meritocracia, gerando uma cobrança das escolas e professores pela melhoria do desempenho dos alunos no SARESP.

Além disso, provavelmente haverá uma revisão da organização do ensino em ciclos no sentido de ampliar a possibilidade de reprovação, já que há indícios, na escola e fora dela, de insatisfação com a atual organização. Acreditamos, porém, que essa revisão não promova uma discussão acerca da avaliação formativa, situando-se apenas na diminuição do número de anos escolares correspondentes a cada ciclo, aumentando a possibilidade de reprovação.

Os resultados das avaliações externas são fundamentais para nortear a ação do Estado, investindo nas escolas, visando à melhoria da qualidade da educação. Mas, ainda vemos na avaliação formativa e na organização do ensino em ciclos o potencial para que os alunos permaneçam e aprendam na escola. Portanto, é preciso resgatar a autonomia da escola na 
construção e execução do seu projeto pedagógico, procurando atender as necessidades de aprendizagem dos seus usuários, em sua maioria meninos e meninas que ainda têm na escola pública o único lugar de acesso ao conhecimento. 


\section{REFERÊNCIAS BIBLIOGRÁFICAS}

AFONSO, Almerindo Janela. Avaliação educacional: regulação e emancipação - para uma sociologia das políticas avaliativas contemporâneas. $3^{a}$ ed. São Paulo: Cortez, 2005.

Avaliar a escola e a gestão escolar: elementos para uma reflexão crítica. In: ESTEBAN, Maria Teresa (org.) Escola, currículo e avaliação. São Paulo: Cortez, 2003.

ALAVARSE, Ocimar Munhoz. Ciclos ou séries?: a democratização do ensino em questão. Tese (Doutorado) - Faculdade de Educação, Universidade de São Paulo, São Paulo, 2007.

Ciclos: a escola em (como) questão. Dissertação (Mestrado) - Faculdade de Educação da USP, São Paulo, 2002.

ARCAS, Paulo Henrique. Avaliação da Aprendizagem no Regime de Progressão Continuada: o que dizem os alunos. Dissertação (Mestrado) - Faculdade de Educação, Universidade de São Paulo, São Paulo, 2003.

ARROYO, M. G. Ciclos de desenvolvimento humano e formação de educadores. Educação e Sociedade, Campinas, v.20, n.68, p.142-162, dez. 1999.

BARBOSA, Geraldo Carlos. A atividade de avaliar no SARESP. Dissertação (Mestrado) Pontifícia Universidade Católica de São Paulo, São Paulo, 2005.

BARRETTO, Elba S. de Sá. A Avaliação na Educação Básica entre dois modelos. Educação \& Sociedade, ano XXII, no 75, p. 48-66, agosto/2001.

BARRETTO, Elba S. de Sá; MITRULIS, Eleny. Os ciclos escolares: elementos de uma trajetória. Cadernos de Pesquisa, São Paulo, n. 108, p. 27-48, Nov. 1999.

BAUER, Adriana. Usos dos Resultados do SARESP: o papel da avaliação nas políticas de formação docente. Dissertação (Mestrado) - Faculdade de Educação, Universidade de São Paulo, São Paulo, 2006. 
BERTAGnA, Regiane Helena. Progressão Continuada: limites e possibilidades. Tese (Doutorado) - Faculdade de Educação, Universidade Estadual de Campinas, Campinas, 2003.

BOGDAN, Robert; BIKLEN, Sari. Investigação Qualitativa em Educação. Porto: Porto Editora, 1994.

BOnAmino, Alicia Catalano de. Tempos de Avaliação Educacional: O SAEB, seus agentes, referências e tendências. Rio de Janeiro: Quartet, 2002.

BOSQUETTI, Maria Carolina Bonna. SARESP/2000 e a questão da visualização em geometria espacial. Dissertação (Mestrado) - Pontifícia Universidade Católica de São Paulo, São Paulo, 2002.

BROADFOOT, Patrícia. Education, assessment and society: a sociological analysis. Buckingham:Open University Press, 1996.

CORTESE, Beatriz Pedro. O que dizem os alunos sobre avaliação. Dissertação (Mestrado) Faculdade de Educação, Universidade de São Paulo, São Paulo, 2004.

CORTELLA, Mario Sergio. A reconstrução da escola (a Educação Municipal em São Paulo de 1989-1991). Em Aberto, Brasília, ano 11, nº 53, p.54-63.

DALBEN, A. I. L. de F. (org.). Singular ou plural?: eis a escola em questão. Belo Horizonte: UFMG/FAE/GAME, 2000.

DELGADO, Adriana Patrício. Um estudo sobre as práticas avaliativas no regime de progressão continuada: limites e possibilidades. Dissertação (Mestrado) - Pontifícia Universidade Católica de São Paulo, São Paulo, 2004.

ESTEVES, Maria E. de P. Pinto e. Sistema de Avaliação de Rendimento Escolar do Estado de São Paulo - SARESP: uma ação planejada. Dissertação (Mestrado) - Pontifícia Universidade Católica de São Paulo, São Paulo, 1998. 
FELIPE, Jesse Pereira. Uma Análise Crítica do Sistema da Avaliação de Rendimento Escolar do Estado de São Paulo SARESP. Dissertação (Mestrado) - Pontifícia Universidade Católica de São Paulo, São Paulo, 1999.

FERNANDES, Claudia de Oliveira. e FREITAS, Luiz Carlos de. Indagações sobre o currículo: currículo e avaliação. Brasília: Ministério da Educação, Secretaria de Educação Básica, 2008.

FREHESE, Eike. Democratização em xeque? Vicissitudes da progressão continuada no ensino paulista em 1999. Dissertação (Mestrado) - Faculdade de Educação, Universidade de São Paulo, São Paulo, 2001.

FREITAS, José Cleber de. Cultura e currículo: uma relação negada na política do sistema de progressão continuada no Estado de São Paulo. Tese (Doutorado) - Pontifícia Universidade Católica de São Paulo, São Paulo, 2000.

FREITAS, Luiz Carlos de. Ciclos, Seriação e Avaliação: confronto de lógicas. São Paulo: Moderna, 2003.

GATTI, Bernardete A. Avaliação Educacional no Brasil: experiências, problemas, recomendações. Estudos em Avaliação Educacional. São Paulo, n. 10, p. 67-80, jul/dez. 1994.

GOMES, Alessandra. Democratização do Ensino em Questão: a relevância política do fim da reprovação escolar. Dissertação (Mestrado) - Faculdade de Educação, Universidade de São Paulo, São Paulo, 2004.

GuILHERME, Claudia Cristina Fiorio. A Progressão Continuada e a inteligência dos professores. Tese (Doutorado) - Faculdade de Ciências e Letras da Universidade Estadual Paulista, Araraquara, 2002.

JEFFREY, Débora Cristina. Representações de docentes sobre o regime de progressão continuada: dilemas e possibilidades. Tese (Doutorado) - Faculdade de Educação, Universidade de São Paulo, São Paulo, 2006. 
KAWAUCHI, Mary. SARESP e Ensino de História: algumas questões. Dissertação (Mestrado) - Faculdade de Educação, Universidade de São Paulo, São Paulo, 2001.

LOPES, Valéria V. Cartografia da Avaliação Educacional no Brasil. Tese (Doutorado) Faculdade de Educação, Universidade de São Paulo, São Paulo, 2007.

MACHADO, Cristiane. Avaliar as Escolas Estaduais Para Quê? Uma análise do uso dos resultados do SARESP 2000. Tese (Doutorado) - Faculdade de Educação, Universidade de São Paulo, São Paulo, 2003.

MAINARDES, Jefferson. Reinterpretando os ciclos de aprendizagem. São Paulo: Cortez, 2007.

A Organização da Escolaridade em Ciclos: ainda um desafio para os sistemas de ensino. In: FRANCO, Creso (org.). Avaliação, ciclos e promoção na educação. Porto Alegre: Artmed Editora, 2001.

OLIVEIRA, Duzolina A. Felipe de. Uma Avaliação Política do Projeto SARESP. Dissertação (Mestrado) - Faculdade de Educação, Universidade de Campinas, Campinas -SP, 1998.

OLIVEIRA, Inês Barbosa de e PACHECO, Dirceu Castilho. Avaliação e currículo no cotidiano escolar. In: ESTEBAN, Maria Teresa (org.) Escola, currículo e avaliação. São Paulo: Cortez, 2003.

OLIVEIRA, Tamara Fresia Mantovani de. O fracasso escolar e a "cultura do ideal" em uma escola da rede estadual paulista sob o regime de progressão continuada. Dissertação (Mestrado) - Pontifícia Universidade Católica de São Paulo, São Paulo, 2002.

OLIVEIRA, Renata de. Implantação do Regime de Progressão Continuada: um estudo sobre a participação dos professores. Dissertação (Mestrado) - Pontifícia Universidade Católica de São Paulo, São Paulo, 2004. 
ORSOLON, Luiza Angelina Marino. O coordenador/formador como um dos agentes de transformação da/na escola. In: ALMEIDA, Laurinda Ramalho de; PLACCO, Vera Maria Nigro de Souza. (org.) O coordenador pedagógico e o espaço da mudança. São Paulo: Edições Loyola, 2001.

PARO, Vitor Henrique. Reprovação escolar: renúncia à educação. São Paulo: Xamã, 2001.

PERRENOUD, Philippe. Os Ciclos de Aprendizagem: um caminho para combater o fracasso escolar. Porto Alegre: Artmed, 2004.

POLICHE, Alessandra Hauk. A progressão continuada e suas implicações na avaliação da aprendizagem. Dissertação (Mestrado) - Pontifícia Universidade Católica de São Paulo, São Paulo, 2006.

RIBEIRO, Alessandro J. Analisando o desempenho de alunos do Ensino Fundamental em Álgebra com base nos dados do SARESP. Dissertação (Mestrado) - Pontifícia Universidade Católica de São Paulo, São Paulo, 2001.

SILVA, Rita de Cássia. Progressão continuada e reprovação: camuflagem ou compromisso? Investigando saberes de professoras primárias e secundárias da Escola Pública. Dissertação (Mestrado) - Faculdade de Ciências e Letras da Universidade Estadual Paulista, Araraquara, 2002.

SOUSA, Sandra M. Zákia L. e BARRETO, Elba S. S. Reflexões sobre as Políticas de Ciclos no Brasil. Cadernos de Pesquisa. São Paulo, v.35, n. 126, p. 659-688, set/dez. 2005.

Estado do conhecimento: ciclos e progressão escolar (1990-2002) - Relatório Final. São Paulo: USP (MEC/INEP/Comped/PNUD), 2004.

SOUSA, Sandra Zákia L. Avaliação e gestão da educação básica. In. Dourado, Luiz. Políticas e gestão da educação no Brasil: novos marcos regulatórios? São Paulo: Editora Xamã, 2009. (no prelo)

Avaliação e carreira do magistério: premiar o mérito? Revista Retratos da Escola. Brasília, v. 2, n. 2-3, p. 81-93, jan/dez. 2008. 
Possíveis Impactos das Políticas de Avaliação no Currículo Escolar. Cadernos de Pesquisa. São Paulo, n. 119, p. 175-190, julho/2003.

SOUSA, Sandra M. Zákia L et all. Construindo o campo e a crítica: o debate In: FREITAS, L. C. Avaliação - construindo o campo e a crítica. Florianópolis: Insular, 2002.

SOUSA, Sandra M. Zákia L. Avaliação de Políticas Educacionais: iniciativas em curso no Brasil. In: HIDALGO, Angela Maria, e SILVA, Ileizi L. F.(orgs.) Educação e Estado: as mudanças nos sistemas de ensino do Brasil e do Paraná na década de 90. Londrina: Ed. UEL, 2001.

A avaliação na organização do ensino em ciclos. In: KRASILCHICK, M. (Org.). USP fala sobre Educação. São Paulo: FEUSP, p.34-43, 2000.

Avaliação do rendimento escolar como instrumento de gestão educacional. In: OLIVEIRA, Dalila Andrade (org.) Gestão democrática da educação: desafios contemporâneos. Petrópolis, RJ: Vozes, 1997.

SOUZA, Roger M. Quadros de. Regime de Ciclos com Progressão Continuada nas Escolas Públicas Paulistas: um cenário para o estudo dos impactos das mudanças educacionais no capital cultural e habitus dos professores. Tese (Doutorado) - Pontifícia Universidade Católica de São Paulo, São Paulo, 2004.

STEINVASCHER, Andrea. A Implantação da Progressão Continuada no Estado de São Paulo: um caminho para a democratização do ensino? Dissertação (Mestrado) - Faculdade de Educação, Universidade de São Paulo, São Paulo, 2003.

VASCONCELlOS, Celso dos S. Coordenação do Trabalho Pedagógico: do projeto político-pedagógico ao cotidiano da sala de aula. $9^{\mathrm{a}}$ ed. São Paulo: Libertad Editora, 2008.

Avaliação da Aprendizagem: Práticas em Mudança - por uma práxis transformadora. São Paulo: Libertad Editora, 1998.

VIANNA, H. M. Fundamentos de um Programa de Avaliação Educacional. Brasília: Liber Livro Editora, 2005. 
Avaliações em Debate: SAEB, ENEM, PROVÃO. Brasília: Plano Editora, 2003.

. Avaliação Educacional: teoria, planejamento, modelos. São Paulo: IBRASA, 2000.

VIÉGAS, Lygia de Sousa. Progressão continuada e suas repercussões na escola pública paulista: concepções de educadores. Dissertação (Mestrado) - Instituto de Psicologia, Universidade de São Paulo, São Paulo, 2002.

ZANINI, Renato. A identidade profissional do professor de Matemática frente ao trabalho docente no Ensino Fundamental em Ciclos. Dissertação (Mestrado) - Pontifícia Universidade Católica de São Paulo, São Paulo, 2006.

\section{DOCUMENTOS OFICIAIS:}

SEE/SP. SARESP: documento de implantação. São Paulo: FDE, 1996

SEE/SP. Caderno de Memórias: Seminário Avaliação Externa, Projeto Político-Pedagógico e o Processo de Ensino e Aprendizagem no Ensino Médio. São Paulo: FDE, 2007.

SÃO PAULO. Resolução SE no 27, de 29 de março de 1996. Dispõe sobre o Sistema de Avaliação do Rendimento Escolar do Estado de São Paulo.

Resolução SE no 35, de 07 de abril de 2000. Dispõe sobre o processo de seleção, escolha e designação de docente para exercer as funções de Professor Coordenador, em escolas da rede estadual de ensino e dá providências correlatas.

Resolução $\mathrm{SE} \mathrm{n}^{\circ}$ 124, de 13 de novembro de 2001. Dispõe sobre a realização das provas de avaliação dos Ciclos I e II do Ensino Fundamental, nas escolas da rede estadual de ensino, em 2001. 
Resolução SE ${ }^{\circ}$ 14, de 18 de janeiro de 2002. Dispõe sobre a realização das provas de Avaliação de Ciclo - SARESP 2001.

. Resolução SE n 120 , de 11 de novembro de 2003. Dispõe sobre a realização das provas de avaliação relativas ao SARESP/2003 - Sistema de Avaliação do Rendimento Escolar do Estado de São Paulo.

Resolução SE no 101, de 18 de novembro de 2004. Dispõe sobre a realização das provas de avaliação relativas ao Sistema de Avaliação do Rendimento Escolar do Estado de São Paulo - SARESP/2004.

Resolução $\mathrm{SE}^{\circ}$ 81, de 19 de outubro de 2005. Dispõe sobre a realização das provas de avaliação relativas ao Sistema de Avaliação do Rendimento Escolar do Estado de São Paulo - SARESP/2005.

- Resolução SE no 66, de 03 de outubro de 2006. Dispõe sobre o processo de credenciamento, seleção e indicação de docentes para o posto de trabalho de Professor Coordenador, em escolas da rede estadual de ensino e dá providências correlatas.

- Resolução SE n ${ }^{\circ}$ 61, de 24 de setembro de 2007. Dispõe sobre o registro do rendimento escolar dos alunos das escolas da Rede Estadual.

Resolução SE $n^{\circ}$ 68, de 18 de outubro de 2007. Dispõe sobre a realização das provas de avaliação relativas ao Sistema de Avaliação do Rendimento Escolar do Estado de São Paulo - SARESP/2007.

Resolução SE $n^{\circ}$ 88, de 19 de dezembro de 2007. Dispõe sobre a função gratificada de Professor Coordenador. 
ANEXO I 


\section{Questionário}

\section{Escola:}

\section{A) Dados Pessoais:}

Idade: anos. Sexo: ( ) Masculino ( ) Feminino

B) Formação:

Licenciatura em:

Ano de conclusão:

1. Pedagogia: ( ) Não

( ) $\operatorname{Sim} \quad$ Ano de conclusão:

2. Complementação Pedagógica: ( ) Não

$$
\text { ( ) Sim Ano de conclusão: }
$$

3. Pós-graduação:
a. Cursos de especialização:
) Não
( ) $\mathrm{Sim}$

Em caso afirmativo, cite os cursos:

b. Mestrado: ( ) Não

$$
\text { ( ) Sim Área: }
$$

c. Doutorado: ( ) Não

( ) Sim Área:

\section{C) Situação Funcional:}

1. Há quanto tempo atua na rede pública estadual?

2. Você é professor: ( ) OFA ( ) Efetivo

Se efetivo, há quanto tempo? anos.

3. Há quanto tempo exerce a função de professor coordenador? anos.

4. Há quanto tempo atua como professor coordenador na escola atual? anos. 
D) Trabalha em outra rede de ensino ou em outra escola? ( ) Sim ( ) Não.

Em caso afirmativo, cite a rede ou escola onde trabalha e a função que desempenha:

\section{E) Responda as seguintes questões:}

1. É comum entre professores, alunos e pais o comentário de que a implantação da progressão continuada gerou mudanças no modo como a avaliação é vivenciada na escola. Em sua opinião a progressão continuada trouxe mudanças na escola em que você atua? Relate o que vem ocorrendo.

2. O SARESP vem sendo aplicado na rede estadual desde o ano de 1996. Enquanto professor coordenador, responda:

a) A escola em que atua vem utilizando os resultados do SARESP? Se a resposta for afirmativa, como são utilizados os resultados? Caso seja negativa, quais os motivos para não utilizá-los?

b) A escola promoveu alguma mudança a partir dos resultados do SARESP? Relate o que vem ocorrendo.

3. Você identifica discrepâncias entre os resultados obtidos pelos alunos na avaliação feita pelo professor e os obtidos no SARESP? Explique sua resposta. 
ANEXO II 


\section{Roteiro para entrevista:}

A- Por que fez a opção por atuar como professor coordenador?

B- Para você qual é a função desse profissional?

C- Que dificuldades enfrenta no desenvolvimento das atividades inerentes a esta função?

\section{1- Progressão continuada}

a. Quando ocorreu a implantação da progressão continuada você atuava como coordenador ou professor?

b. O que você pensa a respeito dessa medida? É a favor, contra, por quê?

c. Na época, que orientações teve a respeito da progressão continuada e especificamente a respeito da avaliação da aprendizagem?

d. Se na ocasião da implantação da progressão continuada estava na sala de aula que mudanças promoveu na sua forma de avaliar os alunos?

e. Se na ocasião estava atuando como professor coordenador que ações desencadeou para orientar a avaliação da aprendizagem?

f. Teve apoio dos órgãos superiores na condução das atividades de orientação aos professores?

g. Que dificuldades enfrentou na escola devido a implantação da progressão continuada? Que ações desenvolveu objetivando o encaminhamento ou solução dessas dificuldades?

h. Como vê a prática avaliativa dos professores após dez anos de vigência da progressão continuada?

i. Como os professores da escola avaliam o trabalho pedagógico hoje?

j. Você identifica mudanças nas práticas avaliativas em decorrência da progressão continuada? Explicite-as.

\section{SARESP}

a. Quando da implantação do SARESP em 1996 que impressões a adoção dessa avaliação externa teve? E durante esses anos de vigência do SARESP, o que pensa a respeito dele? 
b. Você participou do SARESP antes do ano 2001? Participou da equipe que era formada na escola para aplicação, correção e análise dos dados? O que pensava dessa prática?

c. Como professor recebia orientações acerca do SARESP? Quais, quando e por quem eram dadas?

d. Após sua entrada na coordenação pedagógica passou a receber orientações sobre o SARESP? Quais, quando e por quem eram dadas? Essas orientações contribuíram na sua ação na escola?

e. Como você analisa a aplicação e correção do SARESP na escola em que atua?

f. Quando e como utilizam os dados do SARESP em sua escola?

g. Diante da divulgação dos dados do SARESP qual a reação dos professores? Que comentários eles fazem a partir dos resultados?

h. Que ações você desenvolve a partir dos resultados do SARESP? Como orienta a ação dos professores?

i. Que ações os professores vêm desencadeando a partir dos resultados do SARESP?

j. Você identifica alguma mudança nas práticas escolares e nas práticas avaliativas especificamente em função do SARESP? Quais foram as que mais se destacam na escola em que atua? 